\title{
Festival Networks: Stratonikeia and the Sanctuary of Hekate at Lagina
}

In the two previous chapters, we saw how monumental sanctuaries in the civic territory of Mylasa could exhibit very different kinds of relationships with the polis: Labraunda was politically critical for both its strategic location and the symbolic capital of Zeus Labraundos among the wider population. By stark contrast, the sanctuary of the Karian god Sinuri played a central role in the social cohesion of its local community, giving us a microcosmic view of the aggregate polis. This chapter and the next will explore the urban dynamics of two other major sanctuaries in Karia, both of which found themselves within the territory of Mylasa's rising neighbor, the polis of Stratonikeia, roughly 3 o kilometers to the east.

Stratonikeia, a Hellenistic foundation, came to absorb the older sanctuaries of Hekate at Lagina, some eight kilometers north-northwest of the city's center, and Zeus at Panamara, roughly ten kilometers to the southeast (Figure 5.1). A closer examination of this development at each sanctuary will reveal more of the dynamics in the relationship between a country sanctuary and a composite polis. In this case, both sanctuaries ultimately served to foster internal social cohesion but also to establish a wider regional identity. Different from Mylasa, Stratonikeia was a new arrival in the Hellenistic era and both shrines appear to have been pivotal in consolidating the incorporated communities but also in the positioning of the polis on the regional and global map.

Nonetheless, there are two important points of comparison between the younger polis and Mylasa, besides their mutual border and the possession of two major sanctuaries in their respective territories: both poleis were made up of a number of ancient communities, and both were located near the home sanctuary of a Karian federation - for Stratonikeia this was the sanctuary of Zeus Chrysaoreus. Strabo in fact describes the city primarily through the lens of this sanctuary, which has not yet been identified, and that of Hekate at Lagina as follows:

Stratonikeia is a settlement of Macedonians. And this too was adorned with costly improvements by the kings. There are two temples in the country of the Stratonikeians, of which the most famous, that of Hekate, is at Lagina; and it draws great festal assemblies every year. And near the 


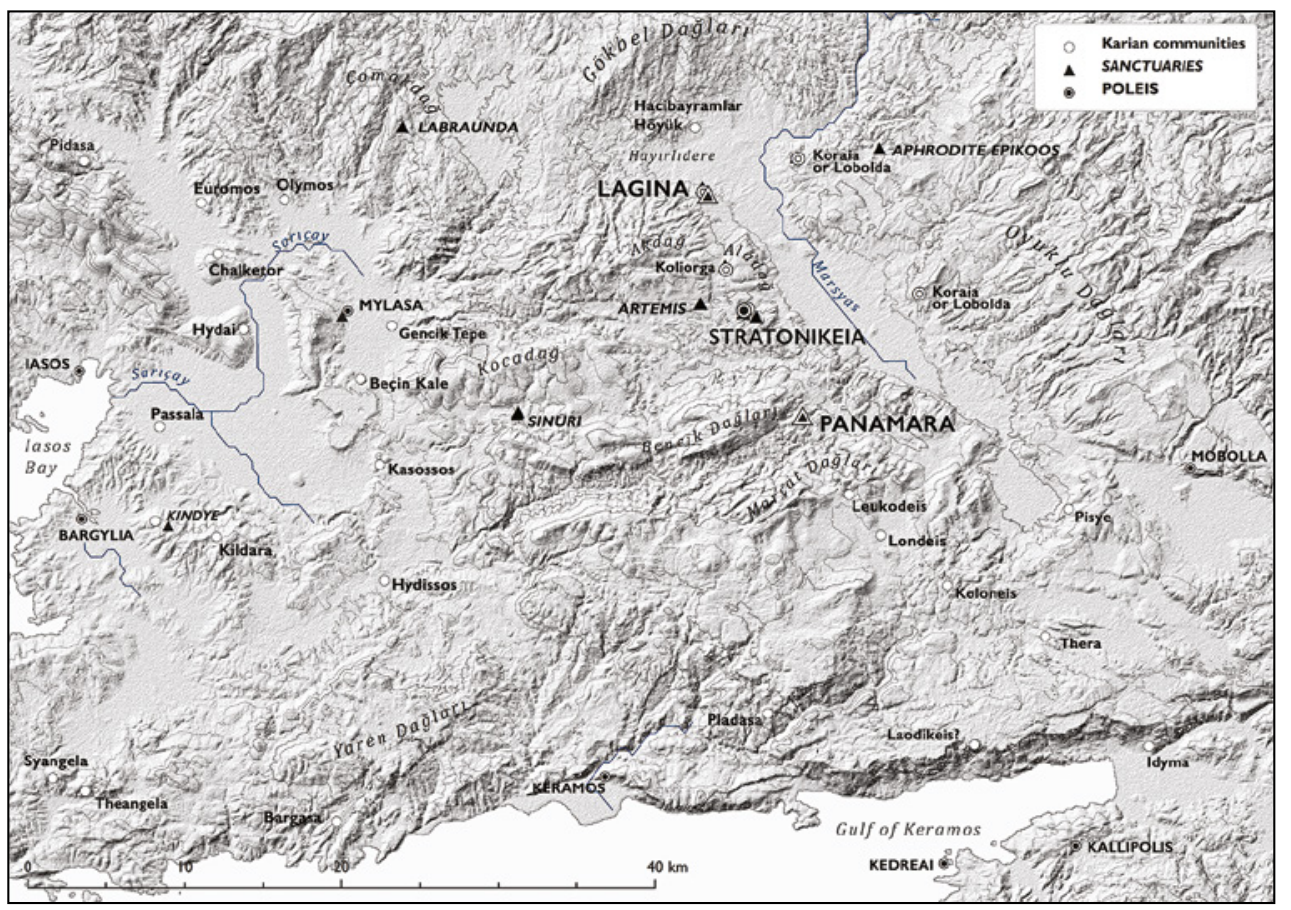

FIGURE 5.1 Map of Stratonikeia and the environment of Lagina and Panamara

city is the temple of Zeus Chrysaoreus, the common possession of all Karians, whither they gather both to offer sacrifice and to deliberate on their common interests. Their League, which consists of villages, is called 'Chrysaorian'. And those who present the most villages have a preference in the vote, like, for example, the people of Keramos. The Stratonikeians also have a share in the League, although they are not of the Karian stock, but because they have villages belonging to the Chrysaorian League. ${ }^{1}$

The sanctuary of Zeus Panamaros, or Zeus Karios as he was originally called, seems to have entirely escaped Strabo's notice, although in his day it surely would have been at least as important as Hekate's sanctuary in Lagina. But what Strabo does show is one of the most important differences between Mylasa and Stratonikeia for this research: while Mylasa was the ancient hometown of the Hekatomnid dynasty which had ruled Karia, Stratonikeia was a newly founded city. The accuracy of Strabo's assertion that the Stratonikeians were 'not of Karian stock' will be disputed below, but it reflects the general

1 Strabo 14.2.25 (transl. H.L. Jones (1929) The geography of Strabo, LCL 223). 
impression of the polis as very much a 'Greek' city, and in any event its origins as a colony. Stratonikeia was in fact founded in a social landscape that was already highly articulated, with archaeological traces of settlement activity that predate the polis. ${ }^{2}$ The sanctuaries at Lagina and Panamara were critical to the physical expansion and consolidation of the chora, or civic territory, but also to its social constitution. They were the primary instruments used in the development of urban identity at Stratonikeia, and for validating the polis in the wider region.

This chapter and the next examine in detail how Stratonikeia appropriated each of these two distant places of cult and utilized them to meet ends, but in different ways. ${ }^{3}$ Below I will first give a framework of the historical development of Stratonikeia before proceeding to examine the sanctuary of Hekate in Lagina. As in the previous chapters, this will begin with a site biography, and a depiction of the available sources, followed by a discussion of the physical environment, and the signs of urban integration, based on monumental space, ritual performances, legal administration, and urban mediatization. It will become apparent that several strategies were simultaneously deployed to create an interlocking pattern of association between cult, place, and polis. The territorial incorporation of these sanctuaries and the areas within their scope will thus have seemed natural and inevitable in the mindset of the wider community. The motives behind this transformation and its impact on the sacred and political landscape, but especially on the communities that lived and worked in them, will be examined after an assessment of the transformations in cult that took place.

\section{$1 \quad$ Stratonikeia - Historical Background}

The area in which Stratonikeia was founded was by no means a vacuum. Finds in the area of the city include two Sub-Mycenaean vases and ceramics from the Geometric period. ${ }^{4}$ Some of these derive from funerary contexts in the necropolis on the northern side of the city. ${ }^{5}$ Several communities in the area are known from the Late Classical and early Hellenistic eras, including Lagina and the nearby community of Koranza, as testified by an inscription under

2 Discussed below.

3 This section draws in part on Williamson (2012), (2013b); van Nijf and Williamson (2015) and (2016).

4 Hanfmann and Waldbaum (1968).

5 I.Stratonikeia III, p. 5. 
Philip II and the satrap Asandros that refers to an asylia originally conferred by Maussollos, stipulating that it was to be posted at the sanctuary in Lagina. ${ }^{6}$

Pausanias mentions of Stratonikeia that the town and its surroundings were once called Chrysaoris. ${ }^{7}$ Stephanus of Byzantium also believed that the first name was Chrysaoris, but was later changed to Idrias, and after this Hekatesia until the new Seleukid settlement. ${ }^{8}$ Shortly before this, however, the name Hiera Kome, or 'Sacred Village', appears in the area. ${ }^{9}$ Şahin argues this as reflecting the home of the sanctuary of Zeus Chrysaoreus, which may have been a strong factor in the Seleukid choice of site; in any case, this name later appears as one of the demes of Stratonikeia. ${ }^{10}$ There are a number of indications that the area of Stratonikeia was either just within, or near, the boundaries of Ptolemaic territory. The Chrysaoric League, for example, was clearly supportive of the Ptolemies and if they met at the sanctuary of Zeus Chrysaoreus at this time then this could have given reason the Seleukids to establish a colony here, as a counterpoint. ${ }^{11}$ Seleukid interest in the area at the time of the founding of the colony is certainly indicated by a heavily fragmented letter by Seleukos I written to an unnamed boule and demos on an architectural block which also carries a list of priests of Zeus Chrysaoreus, ${ }^{12}$ and an honorific decree for a man

$6 \quad$ I.Stratonikeia 5 o1.

7 Paus. 5.21.10, in his discussion of Olympic victor of the pankration and wrestling Aristeas, who was from Stratonikeia; I.Stratonikeia 1042, early first century AD.

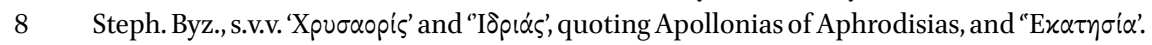
Idrias is also mentioned by Herodotos in 5.118, as a region near the Marsyas, with a place called 'White Pillars' where the Karians met to discuss their strategy. On the names, Sóğüt (2019), 288.

$9 \quad$ I.Stratonikeia 1503 , found at Stratonikeia and pertaining to some issues regarding land between Mylasa and Hiera Kome and arbited by the satrap Asandros; dated to the later fourth century BC.

10 Şahin (1976), 1-15, contra Robert, who suggested that Hiera Kome referred to Lagina as a sacred village, Robert (1937), 555-561; see also I.Stratonikeia III, p. 4-6; Şahin, however, showed that Lagina appears under its own name as a deme of Koranza; his arguments are generally accepted, e.g. Debord (1994) and van Bremen (2000).

11 This is the line of reasoning that Şahin follows in Şahin (1976), 32-33; see also Magie (1950), 995-996, n. 33. The sanctuary of Zeus Chrysaoreus has not yet been located. The Chrysaoric League also met at Labraunda, evidenced by I.Labraunda 43-44, dated to 267 BC, by the mention of Ptolemy II. Other Ptolemaic indications include the earliest text now known from Panamara, I.Stratonikeia 1400, which also mentions Ptolemy II; see Tscherikower (1927), 29 and esp. Debord (2001a), 157-158, and 158-161 mentions the continuing Ptolemaic influence in the urban landscape of Stratonikeia, e.g. attested by the temple to Serapis in Stratonikeia.

12 I.Stratonikeia 1001 is the Seleukid letter, early third century вС, written on the same block as I.Stratonikeia 1063, believed to be from the temple of Zeus Chrysaoreus. 
from Koliorga, a polis that was later absorbed by Stratonikeia, dated to the time of Antiochos II. ${ }^{13}$

Stratonikeia was founded probably in the 26 os BC, by either Antiochos I or II, and was named after Queen Stratonike. ${ }^{14}$ Exactly which shape this took or how this developed in the rest of this century is a rather ambiguous matter. Strabo notes how the city had been 'adorned with costly improvements by the kings,', ${ }^{15}$ but according to Polybius it was soon given to Rhodes after its foundation, by Antiochos II. ${ }^{16}$ If so, this may have been because Rhodes was the most important power in the region that was able to counter-balance the Ptolemies; some believe, however, that Polybius was referring to a gift in the early second century, by Antiochos III. ${ }^{17}$ At least one of the honorific decrees for Rhodians found at Panamara has now been dated to the third century BC, lending support to an early Rhodian influence, if not control, over the entire area. ${ }^{18}$

More certain are the events at the end of the third century and beginning of the second. This is when Philip v occupied the wider area, using Panamara as garrison..$^{19}$ His control lasted only a few years, however, as it was terminated by Antiochos III in 197 BC during his campaign to restore the extent of the ancient Seleukid empire. ${ }^{20}$ In the meantime, Rhodes had tried, unsuccessfully, to take

13 I.Stratonikeia 1030, for Nonnous Arrisios, dated to 'King Antioch, son of Antioch'. Since Koliorga later became a deme of Stratonikeia, Debord inteprets this letter as an indication that Antiochos II, rather than Antiochos I, was the founder of Stratonikeia, Debord (2001a), 157. It is, however, difficult to pinpoint the moment in which Stratonikeia absorbed the surrounding villages and Koliorga may well have retained its independence for some time after the initial foundation of the new polis.

14 Stratonike, daughter of Demetrios Poliorketes, was the wife of Seleukos I (c. 320-281 BC), who gave her in marriage to his son Antiochos I (281-261 BC); according to later accounts because he was violently lovesick for her (Plut. Vit. Demetr. 31, 38; App. Syr. 59). She was also the mother of Antiochos II (261-246 BC) and died at Sardis in 254 BC. On arguments for the foundation under Antiochos I or II, see Debord (2001a), 157.

15 Strabo 14.2.25, quoted at the beginning of this chapter. On the urban infrastructure of Stratonikeia, which was divided into zones marked by temples, see Debord (2001a), 158-162.

16 Polyb. 30.31.6, 'Antiochos son of Seleukos'.

17 Support for a third-century gift of the city to Rhodes is found among Rhodes and Lewis (1997), 272, 349-352; Ma (1999), 68, 277-278; Eckstein (2008), 166; and van Bremen (2008), 1411-1414. On the other hand, Reger (1999), 82-85, and Debord (2001a), 162-163 do not believe that Rhodes actually controlled the area until after it was given it by Antiochos III; Gabrielsen (2000), 171-177 leans towards this view as well.

18 I.Stratonikeia 6, and perhaps I.Stratonikeia 5, through parallels; van Bremen (2008), 1412-1413.

19 I.Stratonikeia 3 and 4 are honorific decrees for Philip and his commander Asklepiades. See also Holleaux (1952), 205-210 on Philip v at Panamara.

On this period see especially Ma (1999), 68-71, 277-278. 
Stratonikeia by force, and Livy mentions that they managed to gain control of Tendeba and Astragon, two fortified places in the territory of Stratonikeia. ${ }^{21} \mathrm{He}$ quickly handed Stratonikeia over, or back, to Rhodes, who maintained control over it and most of southern Karia for the next 30 years. ${ }^{22}$ In 167/6 вC, however, Stratonikeia and other communities voiced their objections to Rhodian rule to Rome, and the island power was forced to withdraw from the area. ${ }^{23}$ Rome granted Stratonikeia her freedom and from this time on the polis began to set out on a course of its own. ${ }^{24}$ The second century BC was then a critical era for the young polis, which seems to have had two basic concerns: negotiating the relationship with the overarching powers in the region, and its own internal territorial composition.

The process of territorial development had everything to do with the social identity of the Stratonikeians. The polis may have began as a 'settlement of Macedonians', as Strabo calls it, yet it became an agglomeration of the surrounding local communities, incorporating them into the new polis as demes. ${ }^{25}$ The evidence for this lies in the first place on the regular appearance of five communities in the demotics on the inscriptions from Stratonikeia: Hiera Kome, Koranza, Koliorga, Koraia, and Lobolda. ${ }^{26}$ As stated above, Hiera Kome is believed to be roughly at the site of Stratonikeia, probably named after the sacred village belonging to the sanctuary of Zeus Chrysaoreus. ${ }^{27}$ Koranza is located about eight kilometers to the north, whereas Koliorga, Koraia and

$21 \quad$ Livy 33.18.22. Tendeba and Astragon have not yet been identified.

22 A later alliance between Stratonikeia and Rhodes through the Chrysaoric League is inferred in I.Stratonikeia 1418 (= EA 35 (2003), 1-7).

23 Polyb. 30.21.2-3 mentions how Stratonikeia and Kaunos both complained to Rome about the harshness of Rhodian rule. Rhodes protested Roman ruling, by stating that Stratonikeia had been a gift to them by Antiochos III in 197 BC, and that they had purchased Kaunos for 200 talents, Polyb. 3.31.6-7.

24 The first issues of Stratonikeian coinage date to this time and may be related to municipal endeavours, see Meadows (2002).

25 Strabo 14.2.25. That the demotics referred to pre-existing communities was first observed by Cousin and Diehl (1887), 33 and later developed by Mehmet Çetin Şahin in Şahin (1976), 1-15 and in I.Stratonikeia III, p. 1-8. The demes are further discussed in Debord (1994) and van Bremen (2000).

26 The frequency of the appearance of the demotics in the inscriptions of Stratonikeia are listed by Şahin in I.Stratonikeia III, 2: Koliorga - 179 times; Hiera Kome - 15 o times; Koraia - 13 o times; Koranza - 106 times; and Lobolda -54 times.

27 Şahin (1976), 1-15 and above. The sanctuary for Zeus Chrysaoreus has not yet been identified. Şahin (1976), 14 locates it on a hilltop just $200 \mathrm{~m}$ east of Stratonikeia (Eskihisar), "at the places called Halkalı and Manastır;" Söğüt (2019), 289-29o considers the area east of the bouleuterion more likely. 
Lobolda have only tentatively been identified at the locations indicated in Figure 5.1. ${ }^{28}$

Three of these - Koranza, Hiera Kome, and Koliorga - already appeared in a fourth century inscription from Sekköy. ${ }^{29}$ Some kind of synoikism must have underpinned the process of incorporating these once independent towns, but when this developed and whether it was designated by a central Seleukid or Rhodian authority or was more of a local initiative is unclear. ${ }^{30}$ In any event, the use of the demotic increases in the later second century (although this coincides with the rise in the epigraphic habit here) and towards the end it becomes so common that the demotics are abbreviated. ${ }^{31}$ This reveals two important aspects that are relevant to this research: on the one hand, the demes, as ancient communities, continued to play a vital role in the identity of individuals throughout antiquity, while on the other, the increasing need to specify deme identity shows an intensive activity in the composite sphere that made up Stratonikeia. Debord already observed how Stratonikeian territory was defined by its religious communities - in the two case studies below I will examine this in more detail. ${ }^{32}$

At least two of these communities, Koranza and Koliorga, had once been independent poleis in their own right. ${ }^{33}$ Koranza covered an extensive area that includes Lagina and continues northwest to the southern rim of the

28 I.Stratonikeia III, p. 1-8 discusses possible locations. Two alternative sites have been proposed for Koliorga, both based on inscriptions: Aydaş (2006) places it at Börükçü, between Stratonikeia and Koranza, while Debord (1994) and Şahin (2008a), 79-81 (and more recently in I.Stratonikeia III, p. 7), both locate it on the hill of Maltepe at Gurbet Köy, roughly seven kilometers west-southwest of Stratonikeia; Şahin further locates Koraia at Çatlı, roughly 15 kilometers east of Stratonikeia (Şahin (2008b), 82 and 86; I.Stratonikeia III, p. 7).

29 Blümel (1990), no. 12. Hiera Kome and Koliorga also figure in the early third century inscriptions, I.Stratonikeia 1001 and 1030, mentioned above. Descat suggested an identification for Sekköy as Talagreia, in a new reading of I.Mylasa 11, Descat (2013).

30 Debord (1994), 117: “En fait, et pour l'essentiel, la nouvelle cité est la produit du synoecisme de communautés cariennes et il est bien probable que les cinq démotiques précités, ceux qui sont tirés des noms de Hiérakomé, Koraza, Koliorga, Koraia, Lobolda, donnent ses composantes initiales."

31 Debord (1994), 117-118; van Bremen (2004b), 214-215. The demotics are typically abbreviated as IE (Hiera Kome), KZ (Koraza), ко (Koliorga), K $\Omega$ (Koraia), $\Lambda \mathrm{O}$ (Lobolda); Laumonier (1958), 197-198.

32 Debord and Varinlioğlu (2001), 191.

33 Blümel (1990), no. 12 is a fourth century inscription from Sekköy listing Koranza and Koliorga as poleis. Şahin believes that by analogy the other communities may also have been referred to as poleis, I.Stratonikeia III, p. 2-3. The name Koranza generally appears as Koraza when it is a deme of Stratonikeia, Şahin (1976), 1 n. 6, and (1973), 188. For the sake of clarity, I will simply use the name Koranza in this study to refer to this community. 


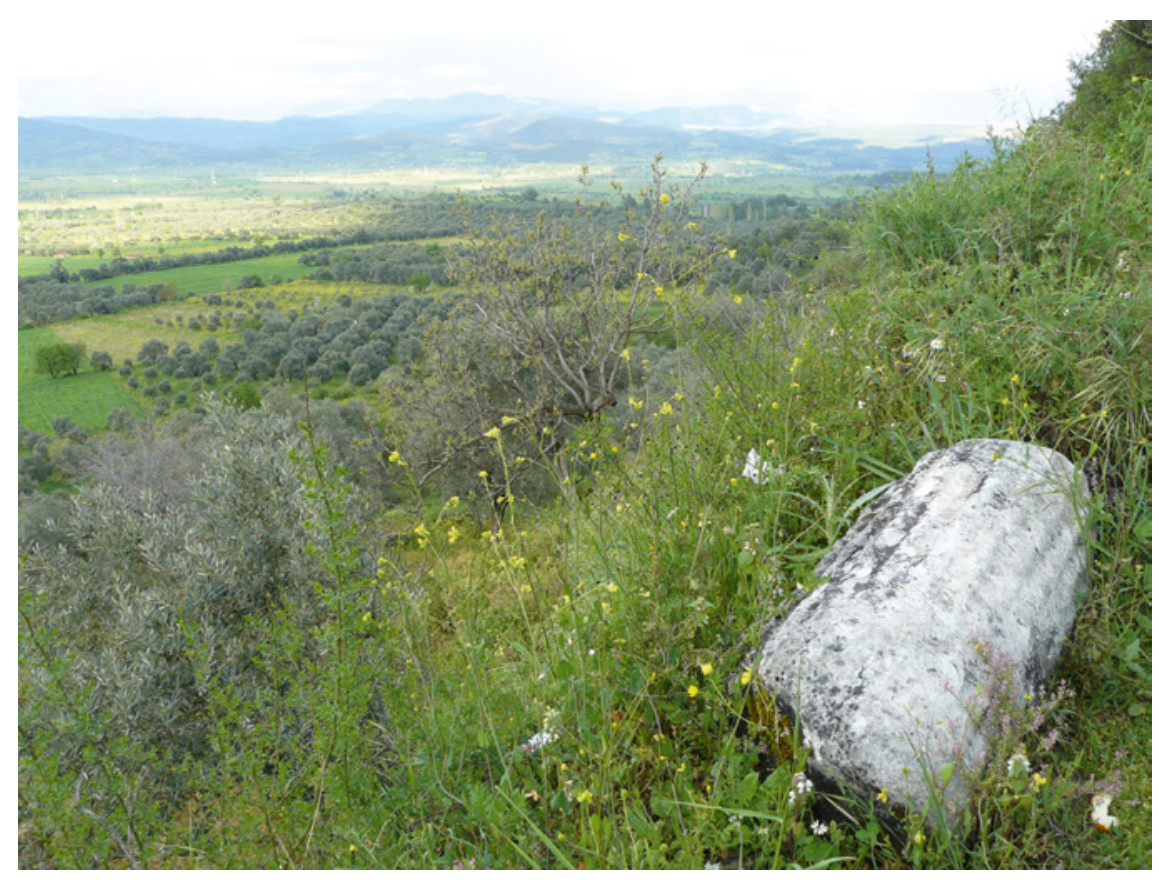

FIGURE 5.2 Koranza. Column from the area of the Apollo and Artemis temple, at the edge of the plateau looking NE, across the Hayrlıdere valley to the Gökbel mountains in the background

PHOTO AUTHOR 2009

Hayırlıdere valley (Figure 5.2). ${ }^{34}$ Although the character of this polis is unclear, whether there was an urban center or more of a distributed settlement, inscriptions show that Koranza had a political decision-making body, with two archons. ${ }^{35}$ Furthermore, it comprised a number of demes of its own, one of which was Lagina. ${ }^{36}$

34 Indicated by Ahmet Tirpan, pers. comm. in April 2009; sporadic finds support this view and Karian settlements are also typically on hillsides; Debord, however, drew a circle around the lower Hayırlıdere valley to indicate the area of Koranza on his map in Debord (1994).

35 I.Stratonikeia 501 , from 323 BC, refers to a grant of tax exemption (ateleia) made by Maussollos and Koranza; I.Stratonikeia 503 is an honorific decree from 318 вС issued by Koranza, together with the main assembly (ekklesias kyrias) and the sacred heralds (hierokerukes), during the archonship of Hyssollos and Obrokon; see also below.

${ }_{3} 6$ I.Stratonikeia $5^{\mathrm{O} 2}$ is a fourth century inscription from Koranza listing its demes as Hythybira, Patarousa, Angorra, Lagina, and Ondra. 
The sanctuary of Hekate was then part of this community, but was clearly under the control of Stratonikeia by the early second century BC, when they added the administration of the cults of Rhodes and Helios to the priesthood of Hekate. ${ }^{37}$ The young polis then had already set its focus on the sanctuary of Hekate as a political platform by this time; the relationship with Lagina was obviously very tight by the mid-second century when, after Stratonikeia was free to mint its own coinage, the goddess appeared on the very first issues. ${ }^{38}$ Zeus also appeared on these early coins, albeit in a very generic form. ${ }^{39}$ It is tempting to see him as Zeus Karios of Panamara, although this presumes an early date for Stratonikeian control of the cult. At some point between its liberation from Rhodes and the mid-second century, Stratonikeia appointed one of its citizens, a certain Leon, as priest of Zeus at Panamara while the sanctuary was still under the administration of the koinon, or community, of the Panamareis. ${ }^{40}$ This appointment, while praised by the Panamareis, marked the beginning of Stratonikeian control at Panamara. ${ }^{41}$ The priests appearing after Leon were from Stratonikeia and the cult seems to have been wholly administered by the polis from that time on. Only a handful of inscriptions show Panamara in the demotic. ${ }^{42}$ Rather than retaining its identity as a subcommunity, it seems more likely that the koinon of the Panamareis was disbanded or absorbed by the polis and redivided among the other demes.

The sanctuaries of Hekate at Lagina and Zeus at Panamara already demonstrate two different kinds of involvement in the second century ВС - Lagina, along with the town of Koranza some eight kilometers to the north, must have already been absorbed by the polis, whereas Panamara, some ten kilometers to the south, appears to have been part of a more gradual process of territorial expansion in this direction.

Territorial expansion must have been high on the agenda of Stratonikeia in the momentum of its new political identity as a free city in the mid-second century BC, especially in the wake of Rhodes' withdrawal. The island power continued to hold much of the area north of the Bay of Keramos, in the subject

$37 \quad$ I.Stratonikeia 504.

38 A chronology for the Hellenistic coinage of Stratonikeia is the topic of Meadows (2002), discussed in more below under Cult Iconography in Civic Contexts.

39 See also Meadows (2002), Group 1; Meadows believes this is Zeus Panamaros, but gives no arguments, whereas in BMC Caria, Head believed it may also represent Zeus Chrysaoreus.

40 I.Stratonikeia 7 ; van Bremen (2004b) and below in Chapter 6. In Karia, the word koinon can represent a number of degrees of community or federated communities; see Debord (2003).

41 See van Bremen (2004b), discussed below.

42 Şahin counts five or six demotic indications of Panamara, I.Stratonikeia III, p. 2; van Bremen (2004b), 215 . 
peraia of Rhodes. ${ }^{43}$ Pierre Debord believes that Stratonikeia was looking to gain critical mass in order to be able to stand up to its powerful and aggressive neighbor to the south. ${ }^{44}$ Even in the later part of the second century вС, Rhodes still expressed its 'hatred' (apechtheia) of Stratonikeia. ${ }^{45}$ The situation of the polis on the brink of territory controlled by hostile Rhodes also figures in Riet van Bremen's analysis of Stratonikeia's selection of Leon as priest at Panamara. She interprets his appointment as a way for the polis to create goodwill in the regions south towards the Gulf of Keramos, allowing for a corridor of safe passage to the coast through territory still held by Rhodes. ${ }^{46}$ Stratonikeia's later possession of Keramos and its holdings, granted by Sulla after the Mithridatic wars of the 80 B $\mathrm{BC}$, was surely anticipated by a longtime influence of the polis in this area. ${ }^{47}$

Boundary disputes with Mylasa prove that Stratonikeian expansion was not just aimed towards the south, however. ${ }^{48}$ Vincent Gabrielsen found an alternative explanation for Stratonikeia's encroaching policies in the second century $\mathrm{BC}$, a time when it was already considerable in size. ${ }^{49}$ He takes into account Strabo's description of the Chrysaoric League, in which every city had a vote-count which corresponded to the number of Karian villages in its territory; Keramos was an example of a polis with a large share in the vote due to its many villages. ${ }^{50}$ Since Stratonikeia was admitted to the league only by virtue of its Karian villages, Gabrielsen considers that the accrual of territory, with villages, by the polis was primarily to gain greater weight within the League. ${ }^{51}$ In any event, the direct economic benefits was surely at least as attractive as an increased vote in the League.

In the first century $\mathrm{BC}$, Stratonikeia acquired a significant land grant from Sulla after the Mithridatic wars but only because of the suffering which the

43 See e.g. Gabrielsen (2000); Wiemer (2010).

44 Debord (2001a), 164.

45 I.Iasos 612, discussed in Ager 1996, no. 161; this concerns a (territorial?) dispute between Rhodes and Stratonikeia, arbited by a Bargylian, dated to the later second century BC, during the Aristonikos wars.

46 Van Bremen (2004b), 237.

47 Van Bremen (2004b), 216-218.

48 I.Mylasa 134 discussed in Ager (1996), no. 101. Mylasa had expansionist tendencies of its own, and much land was invested in the sanctuaries, probably as some kind of security, e.g. as at the sanctuary at Sinuri, with an increase in land leases etc., I.Sinuri $45^{-72 .}$

49 Gabrielsen (2000).

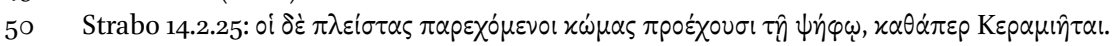

51 Gabrielsen (2000), 156-161; Strabo 14.2.25. See also above Gabrielsen (2011), 341-345, who lists the known members as Mylasa, Stratonikeia, Amyzon, Alabanda, Alinda, Thera, and Keramos, and possibly Panamara. 
polis had endured during its occupation by the Pontic king. Appian relates how Mithridates took the city, imposed a fine, married one of the virgins, and installed a garrison in town. ${ }^{52}$ The violence of the events is reflected through one of the inscriptions, apparently a memorial for the men who died in the war. ${ }^{53}$ Stratonikeia sent an embassy to Rome, to whom it had remained loyal since its freedom, and obtained Sulla's positive reply, the Senatus consultum de Stratonicensibus of 81 вс. ${ }^{54}$ In this document Sulla acknowledges their losses and calls for compensation and the return of the men taken prisoner; he granted Stratonikeia control over the areas of Themessos and Keramos, as well as the lands, harbors, villages, and revenues from the towns, and finally he declared Lagina as inviolate. Sulla's letter was inscribed in full on the walls of Hekate's temple in Lagina, with immediately next to it the list of 57 cities across the Greek world that recognized the asylia and participated in the new festival of the Hekatesia-Romaia celebrating Hekate Soteira Epiphaneia and Thea Rome ${ }^{55}$ The close proximity of these two inscriptions on the wall masks the tremendous effort that Stratonikeia must have invested in organizing the resulting festival and the embassies to all of these cities (Figure 5.25).

A little over 40 years later, Stratonikeia was again under attack, this time by Quintus Labienus. ${ }^{56}$ Labienus had just secured a Parthian contingent to support Brutus in Rome when he learned of his downfall in 42 BC; he changed his plans and took the Parthian troops on a rampage, hoping to conquer Asia Minor, while the Parthians aimed to restore the extent of the old Achaemenid empire. Several cities succumbed or suffered heavy losses, such as Mylasa, but Stratonikeia was one of the few who were able to withstand his attacks. Labienus turned his attention instead towards Lagina, desecrating the sanctuary, and then went to do the same to the sanctuary of Zeus at Panamara. His

$52 \quad$ App. Mith. 21.

53 I.Stratonikeia 1333; van Bremen (2010), 497-499.

54 I.Stratonikeia 505; Sherk and Viereck (1969), 105-111 no. 18; also Sherk (1984), no. 63. The Stratonikeians are also permitted to dedicate a golden crown worth 200 talents to the Roman Senate and to make a sacrifice to Zeus Capitolinus in honor of the victory of Rome, lines $30-33$ and $127-128$. Stratonikeia along with much of Karia seems to have been incorporated in the province of Asia following the Mithridatic wars, rather than after the Aristonikos revolt in the later second century вС; Errington (1987) and Marek (1988).

55 I.Stratonikeia 507-508, discussed among others in Rigsby (1996), 418-423 and Knäpper (2018), 254-256. On incorporating the cult of Thea Romē with a principal deity, see Steuernagel (2010); Buraselis (2012); van Nijf and van Dijk (2020).

56 Cass. Dio 48.26.3-4 shows that of all 'the mainland' cities, Labienus was unable to take Stratonikeia, although he 'besieged it for a long time'. Mylasa and Alabanda were the only other cities to resist him, albeit unsuccessfully. Tac. Ann. 3.62 mentions the 'Parthian' invasion, which Stratonikeia resisted. 
actions verify the intimate bond between the city and these two sanctuaries, as they both came to stand for Stratonikeia: hurting them was an effective way to hurt the polis. ${ }^{57}$ Panamara, however, was also a ready target because of the presence of the Stratonikeian population, whether they took refuge there or were celebrating a festival. In any event, Zeus miraculously intervened in the onslaught that took three days and nights, with lightning, fire, hail, fog, and hallucinations, while the people shouted 'Great is Zeus Panamaros!' Eventually Labienus's troops turned tail and ran off into the wilderness. ${ }^{58}$ This event led to another Stratonikeian embassy to Rome which brought about the Senatus consultum de Panamara, bearing a grant of asylia. ${ }^{59}$ The evidence for the way in which this was celebrated is more poorly preserved than at Lagina, but a fragmented list of cities, mostly Karian, may well be a similar kind of response to the asylia. ${ }^{60}$

By the second and especially first centuries $\mathrm{BC}$, both Hekate of Lagina and Zeus of Panamara had become in every sense the chief urban gods of Stratonikeia, and the polis came to rely on them more than any other deity that resided within the urban limits. The hard-won privilege of asylia which Stratonikeia managed to obtain for both sanctuaries from Rome was precious to the polis and they held on to this as they came to Rome again in $23 \mathrm{AD}$, presenting their case before the reforms tribune under Tiberius, as Tacitus records:

Then the people of Aphrodisias produced a decree of the dictator Cæsar for their old services to his party, and those of Stratonikeia, one lately passed by the Divine Augustus, in which they were commended for having endured the Parthian invasion without wavering in their loyalty to the Roman people. Aphrodisias maintained the worship of Venus; Stratonikeia, that of Jupiter and of Diana of the Cross Ways. ${ }^{61}$

$57 \quad$ Philip v also used this strategy at Pergamon; unable to take the citadel, he instead razed the sanctuary of Athena Nikephoros in the lower plains; Polyb. 16.1.1-9, 18.2.2, 18.6.4; Diod. Sic. 28.5 .

58 Recorded in I.Stratonikeia 10; see also Roussel (1931); Picard (1952); Merkelbach (1968). Discussed further below, in Chapter 6.

59 I.Stratonikeia 11-12; Cousin and Deschamps (1887); Sherk and Viereck (1969), 158-162 no. 27.

$60 \quad$ I.Stratonikeia 21.

61 Tac. Ann. 3.62: Aphrodisienses posthac et Stratonicenses dictatoris Caesaris ob vetusta in partis merita et recens divi Augusti decretum adtulere, laudati quod Parthorum inruptionem nihil mutate in populum Romanum Constantia pertulissent. Sed Aphrodisiensium civitas Veneris, Stratoninicensium Iovis et Trivieae religionem tuebantur (transl. by A.J. Church and W.J. Brodribb eds. (1942) Complete works of Tacitus, New York: Random House). Further discussed in Belloni (1984b) and Berns (2006), among others. 
Stratonikeia thus relied on the historicity of their loyalty to Rome and the resulting claims for their cults of Zeus ('Jove', or Jupiter) and Hekate ('Trivia', associated here with Diana of the Cross Ways). Drawing these two deities, each with their own particular histories and local networks, into such a tight relationship with the polis significantly realigned the fabric of the social, political, and sacred landscapes throughout the area. The hinterland of Stratonikeia was now vast, even for a large polis. George Bean had also already commented that:

As a Hellenistic foundation, Stratonikeia was not divided like Mylasa into tribes and clans, but on the Greek model into tribes and demes. This was, however, a distinction without a difference, for the demes were in fact the old Karian villages, just like the Mylasan clans. ${ }^{62}$

This is Karia, after all. Clusters and networks of communities with nested identities and multiple cross-ties were typical, as Debord observes. ${ }^{63}$ Inscriptions speak of vibrant village life in the countryside of Stratonikeia. ${ }^{64}$ Yet besides the koina and the demes, there was nonetheless a regular Greek-style boule that made decisions with the demos and took action in the interests of the polis of Stratonikeia. ${ }^{65}$ This raises the question of how Stratonikeia, as a new polis, was able to legitimate its identity among all of these multifarious social webs, simultaneously interacting as they had been for ages. The answer appears to lie in the realm of cult - by incorporating those already embedded in these older communities, and by reinventing their rituals and ritual spaces into a newyet-ancient common focus for the polis. The different ways in which the polis pulled this off is the subject of the next two case studies.

$62 \quad \operatorname{Bean}(1971[1989]), 68$.

63 Debord (2003), examining the various kinds of communities labelled with the word koinon.

64 Besides the demes and villages known to exist, several inscriptions show an active rural

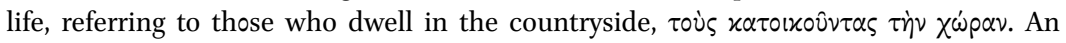
interesting example is I.Stratonikeia 186 from Panamara in the second century AD that specifically mentions Romans as such rural residents; I.Stratonikeia 1325 , lines 11-12 also

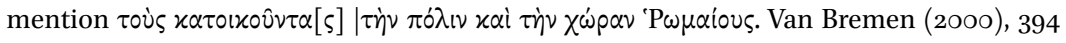
further asserts the demes as the base unit of Stratonikeia, rather than the phylai.

65 For the political system at Stratonikeia, see especially Rhodes and Lewis (1997), 349-352, and Caldesi Valeri (1999). 
The transformation of the modest shrine of Hekate at Lagina into a major urban sanctuary addressed Stratonikeia's needs concerning territorial integrity, social cohesion, and global recognition. Although the origin of this relationship is unclear, it is remarkable given Hekate's traditional role, according to the Oxford Classical Dictionary, as a goddess who is:

possibly of Karian origin ... and certainly outlandish in her infernal aspects, she is more at home on the fringes than in the center of Greek polytheism. Intrinsically ambivalent and polymorphous, she straddles conventional boundaries and eludes definition. ${ }^{67}$

The Karian origins of the goddess are inferred due to the wide popularity of her cult in this region. ${ }^{68}$ Yet even so, Stratonikeia is the only city where the goddess became the poliad deity; unhindered by categorical views of their pantheon, the Stratonikeians seem perfectly at ease as the goddess of the crossroads entered into their mainstream polis religion. They gave a clear definition to her cult at Lagina, and even made sure that it became a focal point on the 'global' map of Greek festivals. The way in which this relationship developed is highly informative of how a sanctuary could serve to consolidate a polis, connect it to a ruling power, in this case Rome, and broadcast its identity to the wider world.

\subsection{Historical Overview of the Sanctuary of Hekate at Lagina}

Although the earliest settlement activity in the area of Lagina dates from the Early Bronze Age, the area was continuously inhabited from the eighth century $\mathrm{BC}$ and onwards, testified by the finds from within the precinct area

66 My thanks again to Professor Ahmet Tirpan for hosting my stay at Turgut with the archaeological team from the Selçuk University of Konya from 14-16 April, 2009, and allowing me to review internal reports and unpublished documents. See also Williamson (2012); Williamson (2013b); Williamson (2013 c).

67 Hornblower and Spawforth (2003) in The Oxford Classical Dictionary, 671. Rutherford (2006), 140 briefly mentions the possibility that Hekate was a Greek or Ahhiyawan import to Karia.

68 Heckenbach in $R E, 2780$, s.v. 'Hekate'; Kraus (1960), 11 and 2o, further discusses the many theophoric names of Hekate in Karia (e.g. Hekatomnos), also Ray (199o), 129; Burkert (1977), 266; Johnston (1999), 205-206. Besides in the area of Stratonikeia, inscriptions indicate that Hekate's cult was known at: Mylasa, I.Mylasa 3o9; Hydai (with Ge), I.Mylasa 905; Herakleia under Latmos, CIG 2897; Hyllarima, Laumonier (1934), 378 no. 41; Tralles, I.Tralleis 11 and 12; on the outskirts of Aphrodisias, Reynolds and Erim (1982), 29; before the gates of Miletos, Milet I.3 133 (lines 25-26 and 28-29). 
of the sanctuary. ${ }^{69}$ This corresponds to a period of general growth throughout this area, with several small settlements developing into sizable communities in the later Archaic and Classical periods (e.g. Koranza, the settlement at Börükçü, the area of Stratonikeia).

The antiquity of the sanctuary of Hekate at Lagina, situated in the community of Koranza some eight kilometers north of Stratonikeia (near modern Turgut), is unknown..$^{70}$ Some of the earliest finds that may be related to the cult include part of a sacrificial decree from the fourth century вс. ${ }^{71}$ Terracotta fragments (votives?) and small golden discs that once adorned clothing, loomweights from the third or early second century, and 387 coins ranging from the fourth to second or perhaps early first century BC. Roughly a third of these are identifiable and show a strong Rhodian presence in the fourth and third centuries, but several are also Macedonian and Seleukid. ${ }^{72} \mathrm{~A}$ few tombs, just north of the sanctuary, coincide with this period. ${ }^{73}$ Towards the end of this century, under the Macedonian satrap Asandros, a decree was posted at the shrine in Lagina acknowledging a grant of asylia originally conferred by Maussollos. ${ }^{74}$

Hekate's place of cult appears to have been architecturally defined prior to the foundation of Stratonikeia, similar to the sanctuary of Artemis and Apollo at Koranza. Roughly 500 meters northwest of Lagina, this sanctuary was situated along the northern perimeter of the plateau of Koranza and looks out across the Hayırlıdere valley to the Gökbel mountains in the north (Figure 5.2). ${ }^{75}$ The several architectural fragments indicate the monumentality. Two fourth-century inscriptions were discovered here: an honorific decree and

69 Tirpan and Söğüt (2005a), 3-4; most of this paragraph draws on this publication.

70 See note 10 above on Lagina or Stratonikeia as Hiera Kome; Robert (1937), 555-561; Şahin (1976), 1-15.

71 I.Stratonikeia 1417 (=EA 34 (2002), no. 1) is a sacrificial decree by a certain Leros and probably his spouse. Şahin dates this inscription to the second half of the fourth century BC, based on analogous letter types with especially I.Stratonikeia 502 . The inscription fragments were discovered during the excavations of the temple cella between 1998 and 20o1, and although Hekate is not explicitly mentioned in the text it seems plausible that her cult is inferred, rather than that of Artemis and Apollo further to the north.

72 These objects were found in the fill of the late second century temple cella, Tirpan and Söğüt (2005a), 3; Trrpan et al. (2012); Büyüközer (2018), with a breakdown of the coins; interestingly 24 coins, second century, were from Alabanda. My thanks to Zeliha Gider for bringing this article to my attention.

73 At Yayalar, between Lagina and Koranza, burials were found dating from the Classical period to the first century AD, Tirpan (1996), 313-320.

74 I.Stratonikeia $5^{\mathrm{O} 1}$, mentioned above.

75 I.Stratonikeia $5^{\circ 2}$ and 503; see further Şahin (1973). Several marble architectural fragments are still visible today. Also Archaic painted terracotta architrave fragments were found in this area (now in Turgut), Trrpan (1996), 54-55. 
a dedication of land to the gods, listing representatives from each of Koranza's five demes. ${ }^{76}$ Both inscriptions thus concern the composition of the polis of Koranza in a sacred context. Combined with the monumental architecture, this indicates the sanctuary of Apollo and Artemis as the religious and political center of Koranza. Hekate, in the meantime, appears to have been more of a peripheral goddess with an open-air cult place along the eastern perimeter of the plateau. It is unknown whether her sacred grove, mentioned in a much later inscription, goes back to this period; in fact very little is known of the features of Hekate's shrine at Lagina prior to Stratonikeia's involvement. ${ }^{77}$

One can only speculate as to why exactly Hekate became Stratonikeia's poliad deity, but it is clear that her cult at Lagina began to blossom with the rise of the polis, rapidly overshadowing the nearby sanctuary of Apollo and Artemis at Koranza. Even while Stratonikeia was under Rhodian rule, the sanctuary at Lagina was used to exhibit political goodwill through the addition of a cult to Helios/Rhodes at Lagina. ${ }^{78}$ Just as significant is an honorific decree by the local Chrysaoric League, whose headquarters were at the sanctuary of Zeus Chrysaoreus just outside Stratonikeia. ${ }^{79}$ But it was at Lagina that they honored a Stratonikeian who had shown benevolence towards the polis Alabanda, referring to an alliance between Stratonikeia and Rhodes during the occupation of the area by Philip v in the Second Macedonian War. ${ }^{80}$ Obviously by the

76 I.Stratonikeia 503 is an honorific decree for Konon, son of Poseidippos, who had shown goodwill towards the polis of Koranza; he is rewarded with citizenship and the right to own land. The heading of this inscription mentions that the decision was taken in the sixth year of the reign of Philip, during the satrapy of Asandros, 318 BC. I.Stratonikeia 502 is a dedication of land by Skoarenos and his wife, listing the ten delegates who were responsible for the inscription; it also shows the land as bordering on land already belonging to Artemis - whether Hekate also owned any land is unknown.

77 Mentioned in I.Stratonikeia 513, which dates from the third century AD.

78 I.Stratonikeia 504 shows the inclusion of the cult of Helios/Rhodes at Lagina. Helios was the principal deity of Rhodes; see also below under Priesthoods.

79 This is not long after they were 'expelled' from Labraunda by Philip v (I.Labraunda 5), see above in Chapter 3; their base at Stratonikeia was the sanctuary of Zeus Chrysaoreus, which has not yet been discovered.

8o I.Stratonikeia 1418 (= EA 35 (2003), 1-7). This inscription was painstakingly pieced together from over eighty fragments, found in the cella fill. It is the second earliest known decree issued by the Chrysaoric League, after I.Labraunda 43, from 267 BC. It goes beyond the scope of this work examine all the ramifications of this document but it implies an alliance between Rhodes and Stratonikeia that is later dispelled during Stratonikeia's 'liberation' from Rhodes by Rome in 167 BC, when Rhodes was expelled from Karia after the Battle of Pydna (Polyb. 30.21.3f). It also implies that Rhodes controlled the area of Stratonikeia both before and after Philip v's invasion at the end of the third century BC, e.g. Ma (1999), 277-278 and Reger (1999), 82-85. Most interesting is that the decree was 


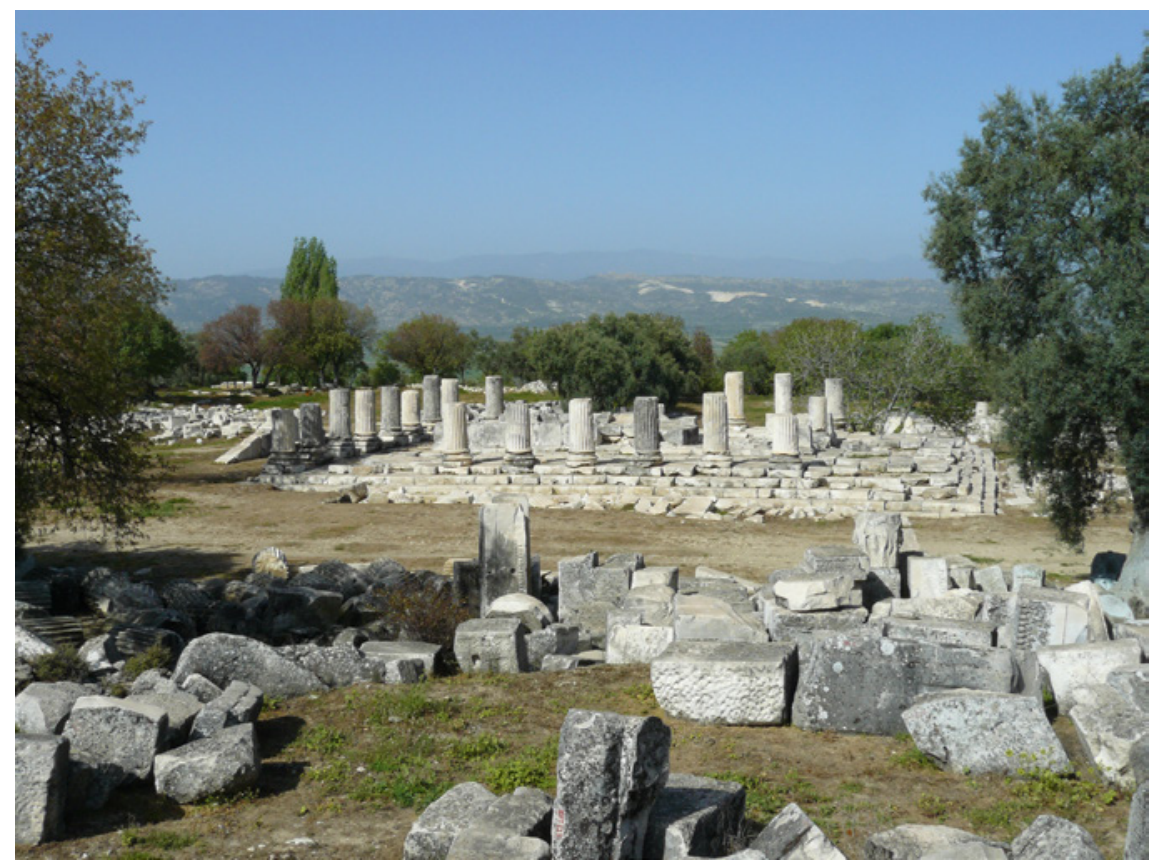

FIGURE 5.3 Lagina. View of the temple from the southwest stoa PHOTO AUTHOR 2008

early second century вС, Lagina was already considered the appropriate place to display ruler support and to honor citizens of Stratonikeia (Figure 5.3).

After Stratonikeia's liberation from Rhodes by Rome in $167 / 6$ вс, Hekate began to appear on the first issues of coins minted by Stratonikeia. By the end of the century her sanctuary was fitted with a monumental stoa complex, altar, and a state-of-the-art temple bearing the well-known frieze with its many allegories to war, peace and the natural order of things. ${ }^{81}$ The sanctuary became an overt symbol of solidarity with Rome after the Mithridatic Wars. The Senatus

inscribed in Lagina while the inscription states that it is to be erected in the sanctuary of Zeus Chrysaoreus, indicating an early political function of the shrine.

81 The frieze has been studied among others by Schober (1933);Junghölter (1989); Baumeister (2007) and van Bremen (2010); interpretations on the date of the frieze, and hence the temple, generally vary from $150-13$ O BC (van Bremen) to after the Mithridatic wars in the 8os BC (Junghölter). While acknowledging the various arguments for these standpoints, for the purposes of this study I will accept Baumeister's proposal of a date for the temple towards the end of the second century BC, i.e. after the Aristonikos revolt of 133-129 BC. This also best corresponds with the coinage as dated in Meadows (2002) (Group 2). On the interpretation of the frieze, see further below. 
consultum de Stratonicensibus of $81 \mathrm{BC},{ }^{82}$ with all its privileges and grants, was inscribed on the temple walls at Lagina for all to see, and the goddess Romē Thea Euergetes was worshiped together with Hekate, now known as Hekate Soteira Epiphaneia. A panhellenic festival, the Hekatesia-Romaia, was held every four years in honor of both goddesses, and cities throughout the Greek world were invited to participate and thus recognize the asylia of this sanctuary near Stratonikeia. This was probably the occasion of the kleidos pompe, the procession in which Hekate's sacred key was carried into the center of town.

The identity of Hekate became thoroughly interwoven with Stratonikeia. This is surely why her sanctuary at Lagina was attacked by Quintus Labienus and his Parthian troops during their invasion in 40 BC. Unable to take the town, they desecrated the sanctuary instead. The substitution of the sanctuary as target instead of the polis already indicates the tight relationship between the city and the goddess. Although the degree to which the sanctuary suffered is unclear, its state of despair did not last long. In fact, this destruction only served to provide yet another opportunity to strengthen ties with Rome when Augustus restored the sanctuary, and Stratonikeia responded by adding the imperial cult to the pantheon in the city and to the games at Lagina, solidifying once more the relationship between city, sanctuary, and ruler, and now empire. ${ }^{83}$

Writing at the time of Augustus, Strabo describes Hekate's sanctuary at Lagina and her festivals as the 'most famous' of Stratonikeia. ${ }^{84}$ Lagina seems to have blossomed in the imperial period; inscriptions testify to the pride taken by the priests of Lagina in their office, as they relate their accomplishments at the end of their term. They furthermore show how the festivals were thoroughly embedded in urban life, along with the cult of Zeus at Panamara. The two cults became more and more intertwined with the city and with each other, as testified by a later inscription on the bouleuterion, prescribing the hymnodes for the festivals at both sanctuaries.

$82 \quad$ I.Stratonikeia 505 with Sulla's reward to Stratonikeia for her loyalty and compensation for her losses incurred during the war.

83 The games of the 'Hekatesia and Kaisareia and Romaia' are referenced in an agonistic inscription, I.Stratonikeia 547. Also, a temple to the Divine Augustus was erected on a platform overlooking the theater in Stratonikeia, Trrpan (1998b). At Lagina a naiskos to the imperial cult was found between the temple and the altar, probably dating from the same period, Tirpan and Söğüt (1999), 156; Söğüt discusses this and a later (second century AD) naiskos for Serapis as likely deriving from the eastern or southern side of the temenos, Söğüt (2008).

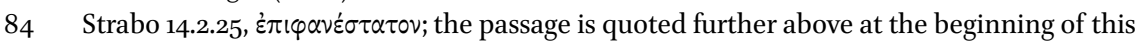
case study. 
It may have been an earthquake that brought the cult to an abrupt end in the fourth century $\mathrm{AD}$, or perhaps a collective conversion of the community to Christianity. A modest church was subsequently built next to the altar, partly incorporating its walls. Towards the end of the century, part of the south wall of the propylon was used for another apsidal structure. Both of these buildings mark the end of one era and the beginning of the next for Lagina, as well as for Stratonikeia.

The cult of Hekate at Lagina lasted for at least five centuries, probably longer. For most of this time it was a place that continuously accumulated meaning and power as an urban platform for Stratonikeia up until the very end. The groundwork for this successful integration lay in the decisions taken in the early period by the polis regarding the cult of Hekate and her sanctuary at Lagina; this will be the focus of the investigations presented below.

\subsection{Data and Sources}

Lagina was first reported by Richard Pococke in 1745 at a place which he refers to as 'Lakena' but was otherwise known as Leïna or Leyne (modern Turgut). ${ }^{85}$ Several expeditions followed in the nineteenth century. ${ }^{86}$ The temple was described among others by C.T. Newton, who discovered sections of the frieze in $1856 .{ }^{87}$ In 1881 an Austrian research team directed by Otto Benndorf traveled through Asia Minor and, after studying the Heroon at Trysa (Göbaşı) in Lykia, they spent some time at Lagina where they produced the first architectural plan of the temple. ${ }^{88}$ They also discovered a number of inscriptions, including the famous Senatus consultum de Stratonicensibus, the letter by Sulla to the Stratonikeians, discussed above; these inscriptions were published in $1884 .{ }^{89}$

In 1891 the illustrious Osman Hamdi Bey, leading figure in Turkish archaeology who excavated at Nemrud Dağ and Sidon and was founding director of the Istanbul Archaeological Museum, visited Lagina together with the French archaeologists J. Chamonard and M. Legrand. ${ }^{90}$ The following year Osman Hamdi Bey began excavations of the site with their assistance, making Lagina

85 Published in Pococke (1745), 65f; William M. Leake observed that the modern name of the site, Leyne (now Turgut) reflected the name of the sanctuary of Hekate, Leake (1824), 23 o.

86 The history of the early investigations and excavations of the site are mentioned in Laumonier (1958), 345-346; Trrpan and Söğüt (2005a), 4-6; Baumeister (2007), 3-5. This section largely draws on their work.

$87 \quad$ Newton and Pullan (1862), 554, including a first sketch of the sanctuary in Table 77.

88 Benndorf (1881).

89 Benndorf and Niemann (1884), 154 f.

90 As an artist, archaeologist, and director, Osman Hamdi Bey (1842-1910) was a true Renaissance man: Radt (2003); Shankland (2004) (Ch. 4); contributions by Ahmet Ersoy (Ch. 9) and Edhem Eldem (Ch. 12) in Inankur et al. (2011); Holod and Ousterhout (2011). 
one of the first fieldwork projects organized and funded by the Ottoman state rather than by foreign institutes. Several sections of the frieze were recovered and transported to the museum in Istanbul, in compliance with the new governmental mandate to prevent more antiquities from going abroad. The Lagina frieze is among the founding pieces in the museum, along with the 'Alexander Sarcophagus' from Sidon. ${ }^{91}$ Subsequent expeditions at Lagina were exclusively focused on the recovery of more inscriptions or sections of the frieze. The frieze, as mentioned above, has been the subject of several studies, the most comprehensive of which was Peter Baumeister's thesis on the style of the frieze which was published in $2007 .^{92}$

Systematic archaeological investigations at the sanctuary were undertaken again nearly a century later, first by Yusuf Boysal in 1966, in connection with investigations of the wider area of Stratonikeia. Long-term fieldwork began in 1993, under the direction of Ahmet Tirpan, of Selçuk University in Konya, with Milas Museum and later Muğla Museum. In 2008, the University of Pammukale, began new excavations of Stratonikeia, under the direction of Bilal Sögüt, who since 2016 is also director of the fieldwork at Lagina. ${ }^{93}$ The surrounding landscape is part of a rescue archaeological project, working ahead of the Yatağan Power Plant that has strip-mined much of the area between Stratonikeia and Lagina, and Panamara, for lignite (brown coal). On a positive note, this has led to a greater archaeological knowledge of this area between the sanctuary and the urban center, more so than at any of the other case studies presented in this volume. As a result, the sanctuary of Hekate is the only one of the case studies that can be demonstrated thus far to have been embedded

91 Radt (2003), 504 mentions Osman Hamdi Bey's unfulfilled plans to rebuild Hekate's entire temple in the gardens of the museum in Istanbul.

92 Baumeister (2007), whose aim is to detect the origins of the different artists at work on the frieze based on stylistic comparison. Previous scholars of the frieze, as mentioned above, include Schober (1933), who first published the frieze in full; Junghölter (1989), who concentrated on the curious 'Nordfries'; Simon (1993), who interprets the frieze from a cosmological point of view, and now van Bremen (2010), who uses comparative epigraphy to re-examine the date and thus the meaning of the frieze, see below under Monumental and Ritual Space.

93 Excavations at Stratonikeia began in 1966 under the direction of Yusuf Boysal. In 1980 the Yatağan Power Plant evacuated the village of Eskihisar, on the site of ancient Stratonikeia, and began open strip-mining - some of the dynamite blasts destroyed the ancient city walls, and Çetin Şahin did what he could to protect the site. In 2008 the University of Pammukale reopened excavations, with the financial help of the Ministry of Culture and Tourism of the Republic of Turkey. A good overview, in English, of the history of fieldwork at Stratonikeia and Lagina is provided in Söğüt (2019), 285, 313-314. 
in an extremely rich cultural landscape, dotted with settlements that date back to at least the Early Bronze Age (indicated in Figure 5.20).

A full publication of the sanctuary is pending, yet several studies of specific features, mostly architectural, have meanwhile appeared by members of the fieldwork team in the new series since 2015 on Stratonikeian research, Stratonikeia Çalıșmaları, edited by director Bilal Söğüt. In 2012, he produced the festschrift From Stratonikeia to Lagina in honour of the previous director, Ahmet Tirpan. New journals, such as Arkhaia Anatolika, regularly feature contributions from the area of Stratonikeia, which also appear in other specialist volumes. ${ }^{94}$ As with all fieldwork in Turkey, general results are summarized annually in the proceedings from the Kazı Sonuçları Toplantısı. The inscriptions have been published by Mehmet Çetin Şahin in the series Inschriften griechischer Städte aus Kleinasien and are being re-examined by Murat Aydaş. ${ }^{95}$ As with every case study discussed in this present volume, a caveat concerning the Hellenistic ceramics must be made as they are underrepresented in the publications. ${ }^{96}$ On the other hand, the coinage of Stratonikeia is a rich source for the relationship between the city and the goddess as Hekate appears on the first issues from the mid-second century BC and onwards. Andrew Meadows' revised chronology for the early issues in his analysis of the Muğla hoard sheds new light in particular on the development of this link as well as the relation between the polis and Panamara, discussed in the next chapter. ${ }^{97}$

\section{Environment of Lagina}

\subsection{Physical Environment}

Located about eight kilometers from Stratonikeia, Lagina is situated near modern Turgut on the northeast perimeter of the lower foothills of the Akdağ, at roughly $470 \mathrm{~m}$ ASL. The sanctuary rests on a gentle slope that descends towards the Hayrrlovasi area, the wide plain between Turgut and the Çine (Marsyas)

94 E.g. Trrpan et al. (2012); Büyüközer (2015). Trrpan's team produced digital reconstructions of the stoa and altar; my thanks here to Aysun Topaloglu and Funda Yürü, for showing me (with permission) their work in the lab at Turgut in April 2009.

95 Die Inschriften von Stratonikeia, 3 vols. (1981-2010), Bonn. Several inscriptions related to Lagina and Koranza have been translated into Turkish by Murat Aydaş (2015).

96 Boysal (1993) mentions the large quantity of Hellenistic material at Lagina.

97 Meadows (2002); the hoard was initially published by Hans von Aulock in von Aulock (1967). Traditional chronologies for Stratonikeian coinage are based on Head's discussions in BMC Caria, esp. Plates 23-24. 


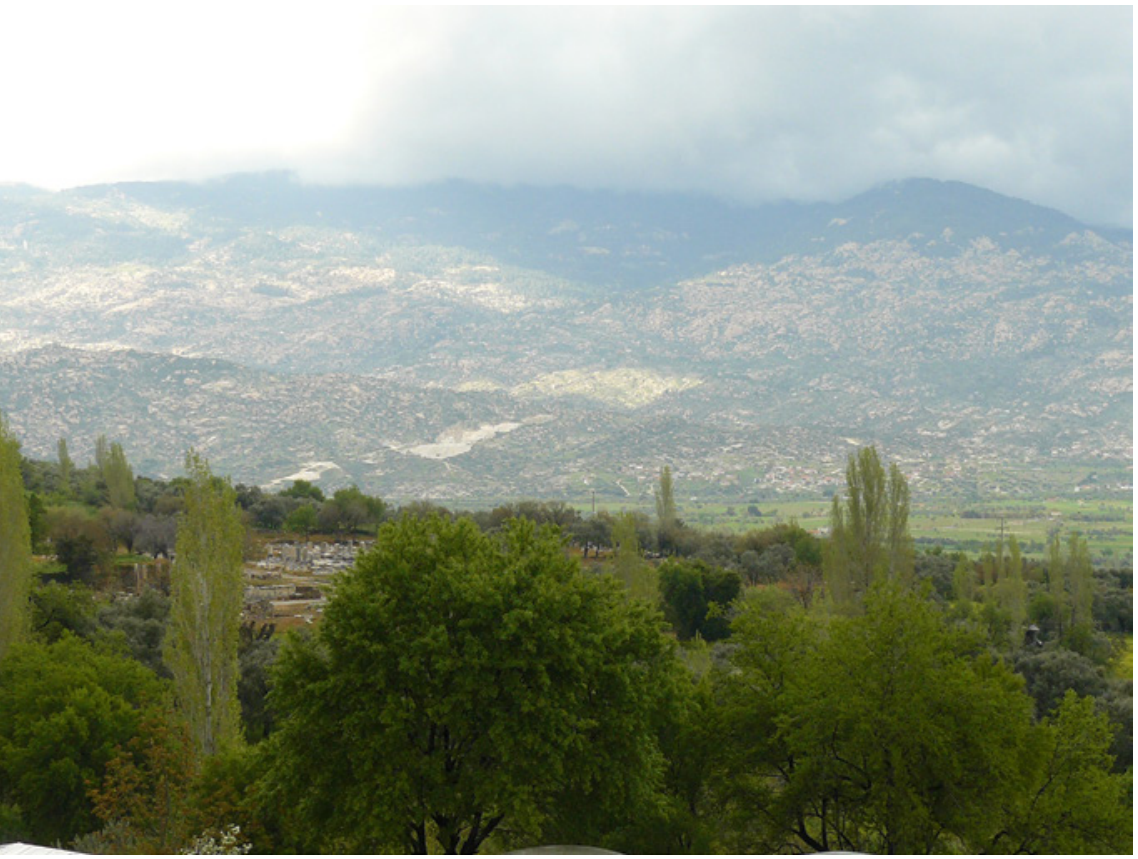

FIGURE 5.4 Lagina. View from the south with the Hayırlıdere valley to the northeast, and the rising Gökbel mountains further north - the Archaic site of Hacibayramlar Höyük was located in the foothills across the valley. The sanctuary of Hekate is visible in the clearing to the left PHOTO AUTHOR 2009

river to the east (Figure 5.4), marking a natural boundary with the Gökbel mountains looming to the north.

The slope circumscribes the eastern end of a plateau which was probably the general area of the ancient community of Koranza. North of this plateau is the green valley of the Hayırlidere river, which empties into the Çine (Figure 5.4). Groves of olive trees surround the sanctuary today, with cultivated fields in the Hayırlovasi plain below. The general area is verdant, with several springs and a stream just south of the sanctuary with another further north, near the Apollo and Artemis sanctuary of Koranza. The area is well-watered and prior to excavation the sanctuary was covered by thick layers of sediment from the runoff carried downhill (Figure 5.18 shows the high trench wall left from the excavations, behind the main propylon). In antiquity, drains were laid that would have helped carry away excess water; ${ }^{98}$ today the sanctuary can

98 Terracotta pipes, probably Roman, crisscross the site (personal observation 2008, 2009); Marcus Sempronius Clemens, a Stratonikeian notable from the later second or early third 


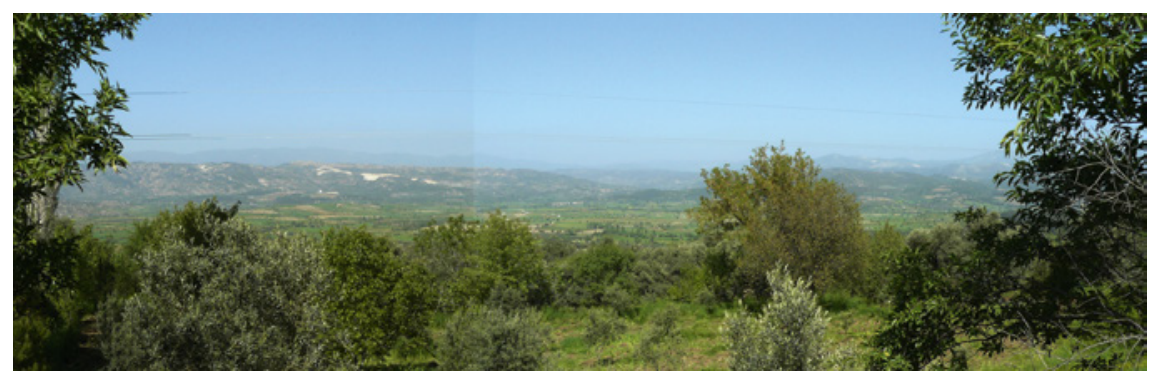

FIGURE 5.5 View from Lagina towards the east-northeast across the Hayırlıvasi area and the Marsyas valley PHOTO AUTHOR 2009

become marshy after rainfall. The impact of earthquakes on the area can still be seen today in the undulating foundation of the temple and altar area. ${ }^{99}$

\subsection{Social-Geographical Location}

Lagina lies on a slope near the eastern rim of the plateau of Koranza. The sanctuary may have marked the extent of the settlement, although the community would likely have kept fields in the fertile plain below. Five-hundred meters to the north lies the sanctuary of Apollo and Artemis, on a steeper part of the plateau and probably marking the northern perimeter of the settled area. With its monumentality, this shrine would surely have been visible from the plain and the mountains to the north, including the Archaic settlement at Hacibayramlar Höyük, located directly opposite the plateau in the foothills of the Gökbel mountains (Figures 5.2, 5.4).

Lagina is located along the western edge of the Marsyas valley (Figure 5.5), the main north-south route that connected Tralles in the Maeander valley with the towns of Alabanda, Stratonikeia, Pisye, and Idyma in the Bay of Keramos. In describing Karia and the distances when crossing it, Strabo notably includes Lagina:

Artemidoros says that, as one goes from Physkos, in the Peraea of the Rhodians, to Ephesos, the distance to Lagina is eight hundred and fifty stadia; and thence to Alabanda, two hundred and fifty more; and to Tralles one hundred and sixty. But one comes to the road that leads into

century AD, claims among his municipal deeds to have commissioned a system to con-

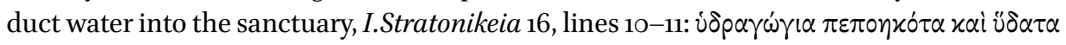

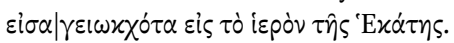

99 Söğüt (2019), 313, 316 mentions earthquakes in 139 AD and 365 AD. 
Tralles after crossing the Maeander River, at about the middle of the journey, where are the boundaries of Karia. ${ }^{100}$

Lagina surely owes its landmark status to the fame of its sanctuary and festivals, as will be shown below, but Strabo probably also mentions it because of its location roughly midway in the Marsyas valley. Physkos is on the southern coast of the Datça peninsula and traveling to Ephesos from there by land would have taken one up the Marsyas valley towards Lagina. Also, Lagina lies just opposite the place where the valley narrows as it makes a sharp bend to the east near Yava, which may have been another one of the demes of Stratonikeia (Koraia or Lobolda?).

Hekate is traditionally the goddess of the wayside, or crossroads, and although this is hardly pronounced in her cult at Lagina - the goddess is never represented as trimorphic - ${ }^{101}$ the very location of her cult place, at the intersection of the two valleys, is nonetheless characteristic. It is likely that the Hayırlıdere river or the Gökbel range to the north marked the northern borders of Stratonikeian territory. The sanctuary of Hekate may well have served as a point of orientation as one traveled north towards Alabanda in the Marsyas valley, from where one would continue on to Tralles in the Maeander valley, and from there to Ephesos (Figures 5.4 and 5.5; see also Figure 2.1). Lagina was clearly well known, perhaps even more than Stratonikeia, which lay in a valley to the west of the Marsyas; envoys could also easily have reached Lagina for the festivals without having to go through Stratonikeia.

Stratonikeia and Lagina were, however, connected by a road that passed between the Akdağ and the Aladağ mountains; the route of the road is discussed in more detail below, including the settlement at Börükçü. The road would have existed long before the foundation of the polis since it would have provided the main means of access between the many settlements already in the area, as Figures 5.1 and 5.20 indicate. In fact, the road continued to be the primary route from the town of Eskihisar (on the site of Stratonikeia) to Yeşilbağçllar and Turgut until the area was evacuated in the 1970s (Figure 5.21). ${ }^{102}$ The modern

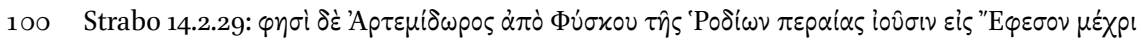

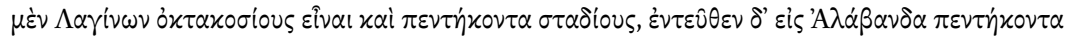

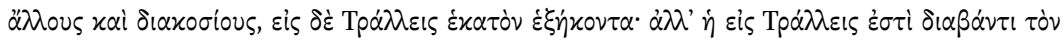

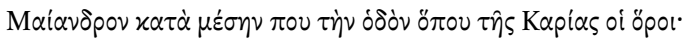

101 Images of Hekate typically show her with three bodies, back-to-back, facing in three different directions (such as the Hekate Chiaramonti in the Vatican museum, a Roman copy of a Hellenistic original); according to Pausanias the trimorphic representation of Hekate was invented by Alkamenes (2.30.2). The goddess' Latin name is Trivia.

102 Hild (2014), 45-46. 
road to Turgut and Lagina now runs through the ancient Marsyas valley, skirting the eastern flank of the Aladağ.

\subsection{Visibility}

A striking aspect of the relationship between Stratonikeia and its urban sanctuaries at Lagina and at Panamara was the lack of intervisibility. As tightly as these sanctuaries were connected to the urban center of Stratonikeia, and as much as they were monumentalized and became landmarks for the environment, neither sanctuary could actually be seen from the town itself. The Aladağ peak and its western foothills blocked the view towards Lagina. Yet several other places in the region did have a view of these sanctuaries. A simple viewshed analysis shows that both of Stratonikeia's major country sanctuaries enjoyed a wide perspective of views, some of which were overlapping but most of which supplemented each other (Figure 5.6).

As described above, Lagina is situated on a hillside in a curve where the Hayırlıdere valley to the north opens onto the Çine (Marsyas) valley to the

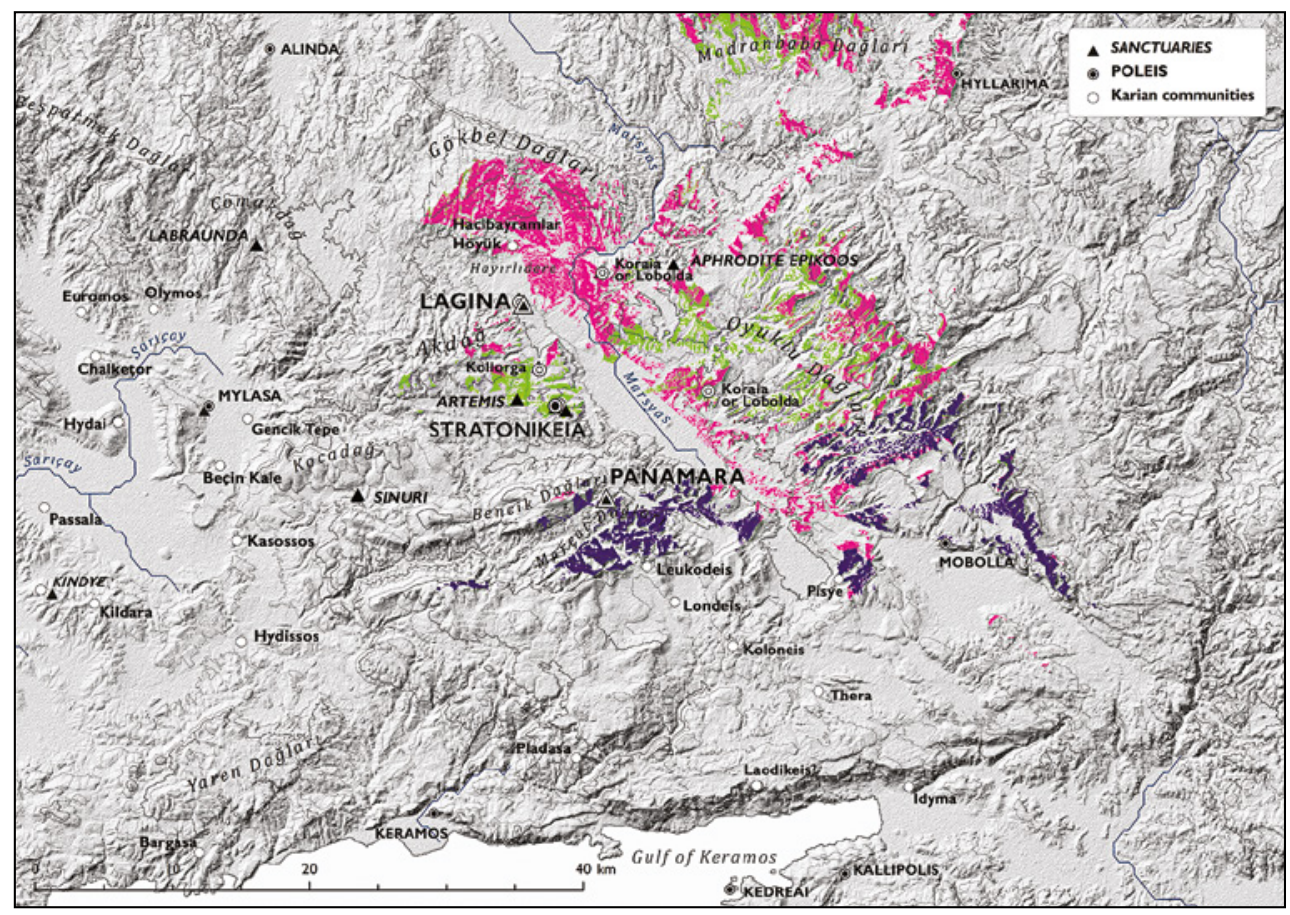

FIGURE 5.6 The combined viewsheds of Stratonikeia (green), Lagina (fuchsia) and Panamara (violet); together these encompassed the known incorporated communities, except Kurbet Köy (possibly Koliorga) to the west 
east. Although the hillside itself obscures the view to the nearby sanctuary of Apollo and Artemis, it does afford a wide panorama to the north, the east in particular, and the southeast. Directly north across the Hayrlıdere was the Archaic site of Hacibayramlar Höyük; the view continues to the Gökbel mountains farther to the north and west along the valley, to the western hills beyond that separate Lagina from the sanctuary of Zeus at Labraunda, some 20 kilometers away. In the opposite direction, just across the Marsyas, the sanctuary of Aphrodite Epekoos at Yava (ancient Koraia or Lobolda?) to the east would have been clearly visible. Far beyond this, to the northeast, are the peaks of Heşimler and Madranbaba, west of the valley of the Akçay (Dandalos); this is the area of the highland Karian towns of Bargasa and Hyllarima. To the east the view from Lagina extends across the Marsyas valley towards the Oyuklu range dominating the other side of the valley (Figure 5.6), near ancient Kys, and continues south beyond Muğla and Pisye; several hills along the western side of the Marsyas valley are also visible, including the range that separates the valley from Panamara. The northern flank of Bencik Dağı, that obscures the view from Stratonikeia to Panamara, is also visible from Lagina. North of Stratonikeia, both the Aladağ peak and the Akdağ mountain, which leads down to the foothills at Turgut and Lagina, are well within view and may even have determined the southwest and southeast axes of the sanctuary, as discussed in more detail below.

Including Lagina within the urban sphere of Stratonikeia was a way of foregrounding this area in the minds of all the Stratonikeians, not just those from Koranza, bringing it mentally closer to the administrative center by association. Moreover, Lagina acted as a visual hinge as it added all of the areas in its own visual region, i.e. the places connected within the same viewshed from the sanctuary, to the visual region of Stratonikeia, thereby also drawing this fertile area of the Marsyas valley into the cognitive collages of the inhabitants. ${ }^{103}$

Signs of Urban Integration at Lagina

While Hekate is characteristically seen as a goddess of the wayside, Stratonikeia turned the cult into the center of public focus, as the goddess become the protective deity of the polis. Although the majority of epigraphic evidence dates from the imperial period, it will be demonstrated that the cult of the goddess and the goals of the polis coalesced in the Hellenistic period, at least by the

103 The terms 'foregrounding', 'visual region', and 'cognitive collages' refer to the cognitive ways of perceiving and remembering space, see Chapter 2. 


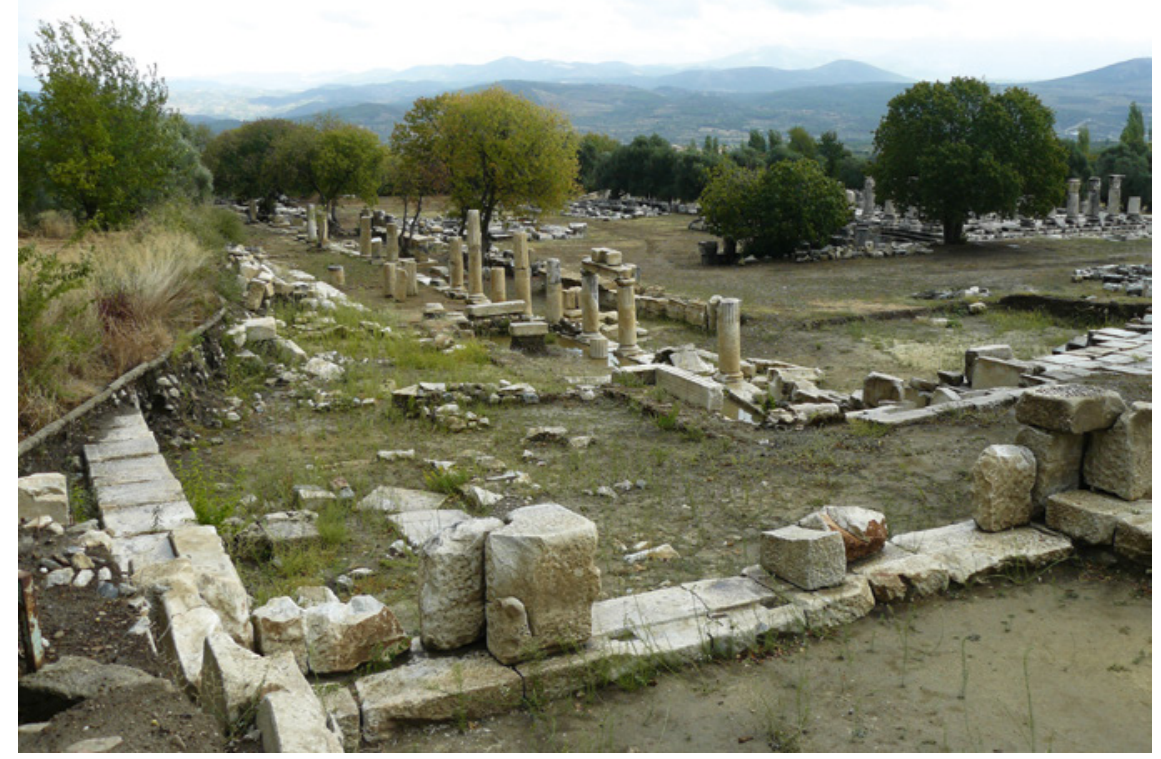

FIGURE 5.7 Lagina. View across the sanctuary from the northwest corner to the east with the Oyuklu mountains in the distance Pното AUTHOR 2011

second century вС if not before. It will also become apparent how the polis used the sanctuary to generate internal social cohesion, develop its civic institutions, and gain external recognition in the wider Greek world.

\subsection{Monumental and Ritual Space at Lagina}

Hekate is seldom associated with monumental temple architecture and her cult place at Lagina was typical in this respect until the construction of the grand complex in the latter part of the second century вС (Figures 5.3, 5.7). ${ }^{104}$ Perhaps part of a wider Stratonikeian building program that commenced some time after its liberation from Rhodes, the design of the complex is certainly worthy of an urban goddess. ${ }^{105}$ Ritual space was radically redefined, as the

104 Hekate also had minor temples at the city gates of Miletos (Milet I.3 172, p. 392), and on Aegina according to Pausanias, with a wooden image made by Myron (2.30.2). Dates for the temple vary between the mid-second century and the early part of the first century $\mathrm{BC}$, see the discussion below on the frieze.

105 The gymnasium was probably one of the first buildings erected at Stratonikeia; Mert (2008), 16-20 and 156-166, dates it to shortly before the mid-second century BC based 
complex created both an inward-facing enclosed area and an external landmark, greatly expanding thereby the spatial and visual impact of the cult in its landscape. Similarly, the frieze, for which the temple is famous, added a new layer of meaning and representation, echoed by the inscriptions that later followed. All of these elements together formed a tremendous vortex, drawing visitors in from the sacred road through the monumental space and towards the temple and altar.

\subsubsection{Architecture}

Architectural evidence suggests a monumental phase of the sacred complex at Lagina in the fourth century BC that includes the temple, propylon, and stoas. ${ }^{106}$ Sondages in the bothros below the temple floor revealed prominent signs of cult activity from the fourth to at least the second and perhaps first century ВС. ${ }^{107}$ The community at Koranza appears to have heavily invested in the temple prior to the advent of Stratonikeia. By the second century BC, the shrine had become a podium for external relations. An early indication is the small Ionic entablature, bearing the inscription of its dedicator, and thought to be from a naiskos, or small shrine, that was possibly erected during Rhodian control of the area in the first part of the second century вс. ${ }^{108}$ Stratonikeia's involvement at the shrine surely predates its liberation from Rhodian control, but visible indications of this only appear in the later second century вС, as it refurbished the temple of Hekate. By this time the precinct comprised roughly a hectare of leveled land, $113 \times 150 \mathrm{~m}$, enclosed by stoas that encompassed the

on inscriptions as well as the style of the Corinthian capital. Rumscheid (1994), 139-140, however, dates it to the same period as the temple of Hekate, based on the similarity of the Corinthian capitals; he dates both structures to the early first century вс. Baumeister observes how fragile the evidence is for a true building program in second-century Stratonikeia, Baumeister (2007), 15, 162, although the gymnasium, theater, bouleuterion, and the temple of Hekate are clearly key projects.

106 Rumscheid (1994), 23; Tirpan et al. (2012), 196-197; Pedersen (2012); Büyüközer (2018).

107 Tirpan et al. (2012), 196-197, discusses the excavations, from 1999-2002, at a depth of $1.75 \mathrm{~m}$ below the floor of the cella, tantalizingly mentions that "... ashes, partially burned pieces of figurines, a great number of glass amulets in various colors, dress ornaments in rosette form, ivory objects, an inscribed stele [I.Stratonikeia 1417, from the second half of the fourth century вС, and I.Stratonikeia 1418, a decree by the Chrysaoric League from the first part of the second century $\mathrm{BC}]$, and coins dated between the beginning of the 4th с вС and the end of the 2nd с вС were found." Büyüközer (2018), 22, mentions finds from the fourth to early first century $\mathrm{BC}$, indicating this as a terminus post quem for the Corinthian temple.

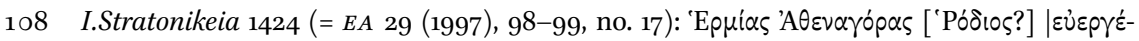
$\tau \eta[\varsigma]$. Şahin believes the benefactor to be Rhodian, based on his Dorian name, and so dates the inscription and entablature to the first part of the second century вС. 


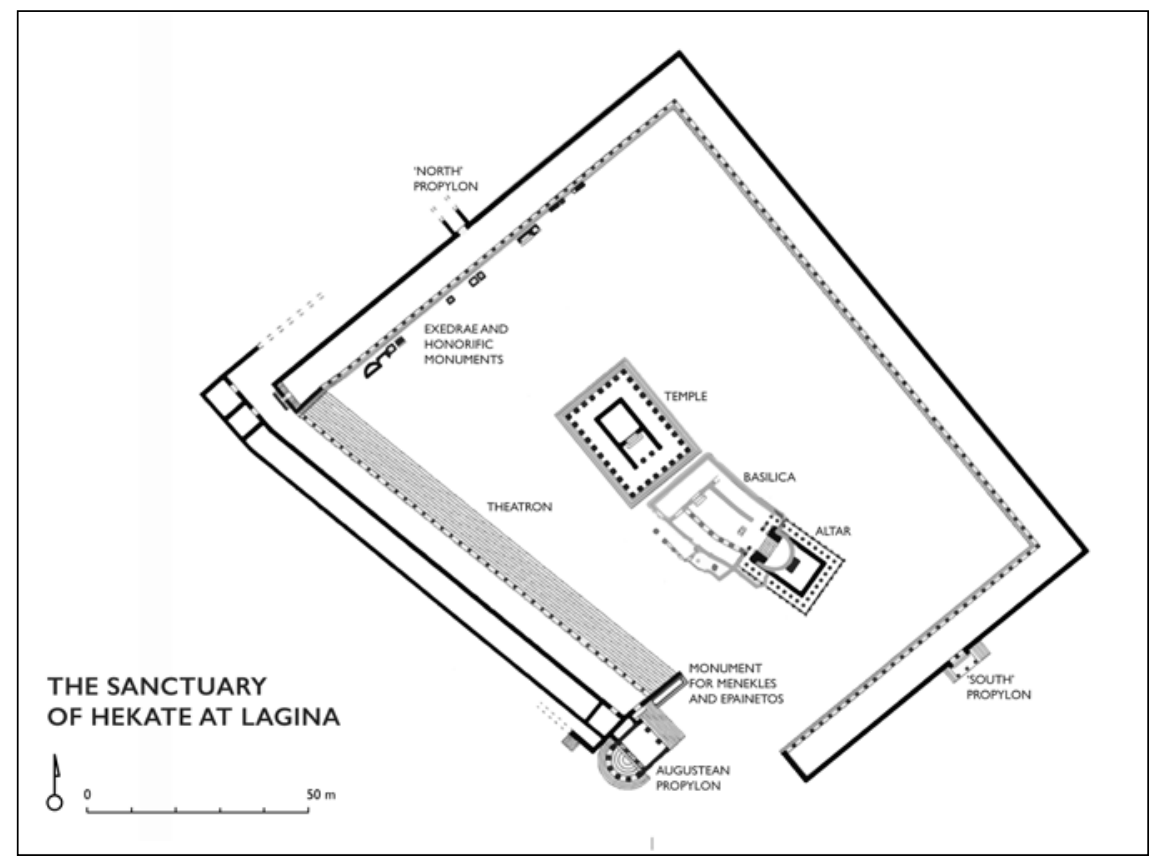

FIGURE 5.8 Plan of the sanctuary complex of Hekate at Lagina by the first century вС PLAN AFTER Z. GIDER, IN GIDER (2012), WITH PERMISSION

temple and altar inside. Inscriptions from the imperial period refer to the complex and environs as the peripolion, indicating a kind of suburb in its own right (Figure 5.8). ${ }^{109}$

Access to Hekate's sanctuary was formally marked by a propylon, or gateway, now one of the most notable features due to the doorway still standing on site (Figure 5.9). The innovative structure, with a semi-circular prostylos

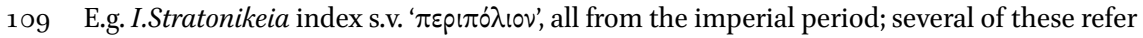
to those living in the peripolion, see below under Local Community. On the peripolion at Lagina, see: Laumonier (1958), 346-347, 363-365, who believes it to refer to the sacred complex, enclosed by the stoai; Schuler (2010), 401 and 411 no. 8, who discusses this in context with other uses of the term peripolion (e.g. in Lykia, Termessos, Rhodes, Kos) - in Lykia the term typically refers to a politically structured community or village dependent on a polis, perhaps in sympoliteia; İplikçioğlu (2004), $116 \mathrm{n}$. 87 who assesses the uses of the term peripolion in imperial inscriptions form Stratonikeia, concluding that the term specifically refers to the temple complex of Hekate in Lagina, rather than a structured settlement; Aydaş (2015) believes this to refer to Hekate's city. 


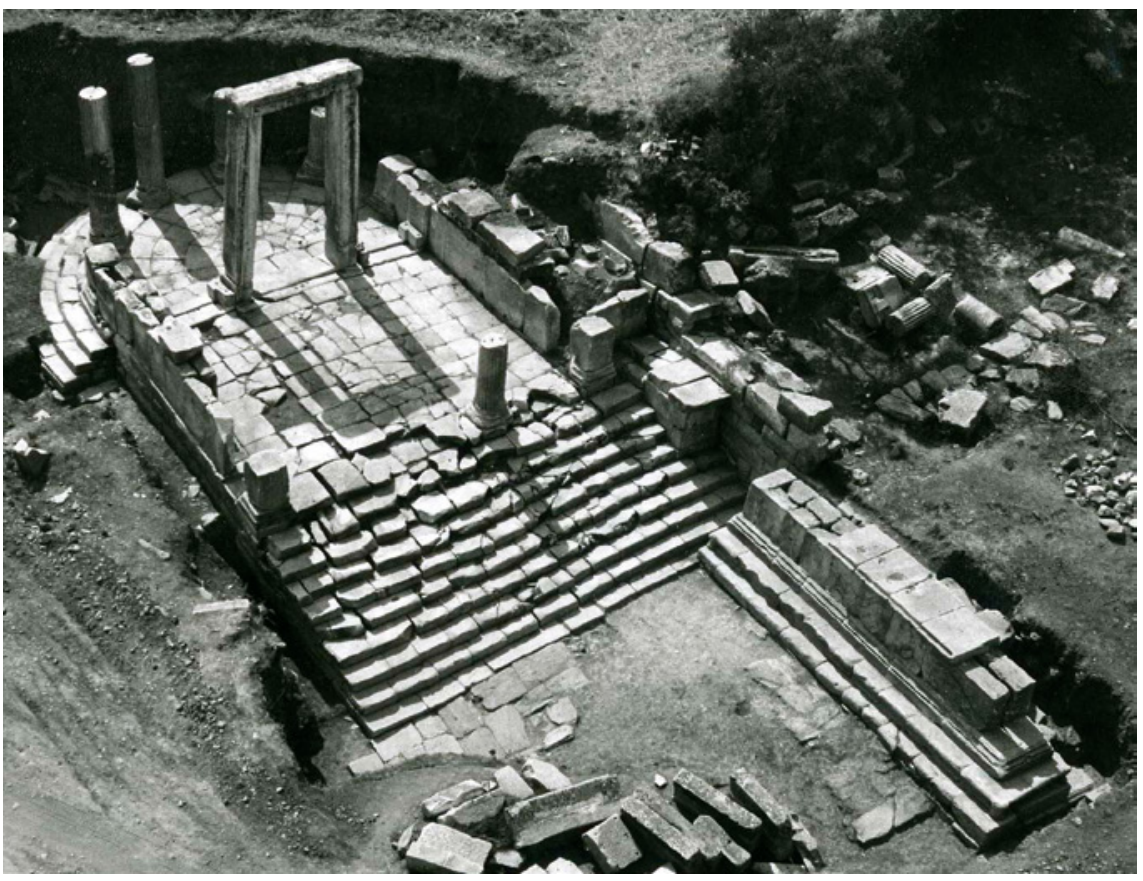

FIGURE 5.9 Aerial photo of the propylon, seen from the east PHOTO COURTESY OF PROF. AHMET TIRPAN

porch on the exterior, was rebuilt by Augustus, but possibly on a Hellenistic foundation. 110

Four steps led the visitor up from the sacred road to the threshold with three gateways. From there he or she would then descend ten steps down into an enclosed temenos defined by the surrounding stoa (Figures $5 \cdot 7$ and 5.10-5.11). The southwest wing, with the theatron, connects to this propylon and was (re)constructed at the same time. ${ }^{111}$ This wing deviates from the orientation of the rest, which follows the alignment of the temple.

110 Based on the consistency of the visible dovetail clamps with third-century architecture, Pedersen (2012), 515-516. The propylon was restored by Augustus, as is recorded in the

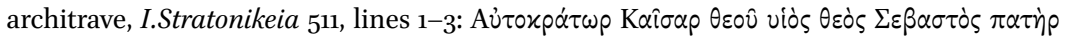

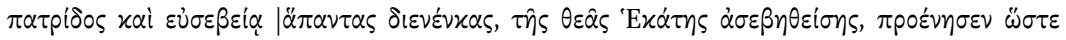

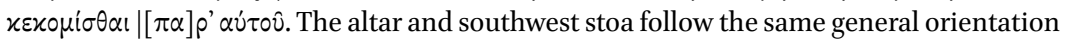
as the propylon and may have been rebuilt at the same time, Tirpan and Söğü (2007b), 592-593. Tırpan and Söğüt (2007b), 592-593; also Tırpan (20o8), 449-451, and Carboni (2013), 64-66.

111 As suggested in Tirpan and Söğüt (2007b), 592-593; also Tirpan (2008), 449-451, and Carboni (2013), 64-66. This was surely the dysmike stoa dedicated by the priest Aristeas, son of Aetion, of Koranza, in I.Stratonikeia 653. 


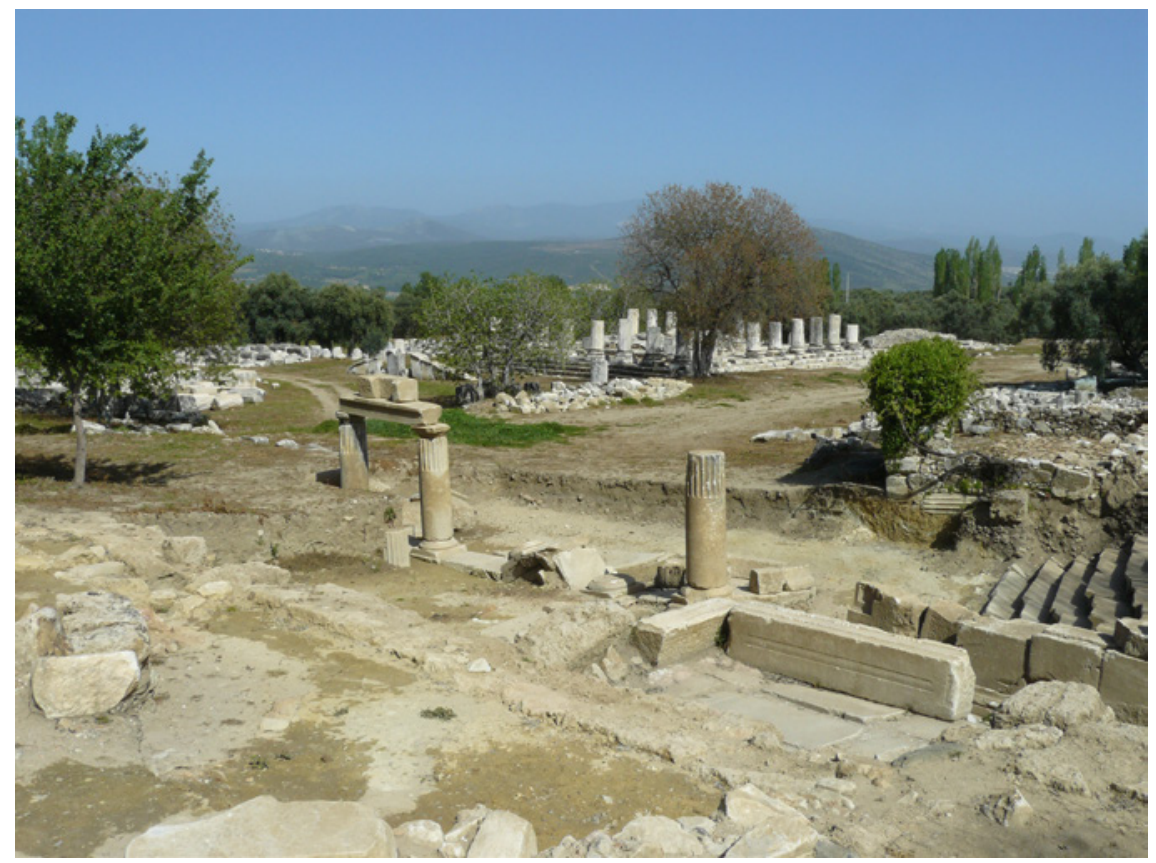

FIGURE 5.10 Lagina. From the northwest corner of the stoa complex. The theatron is visible in the lower right, the temple in the center

PHOTO AUTHOR 2008

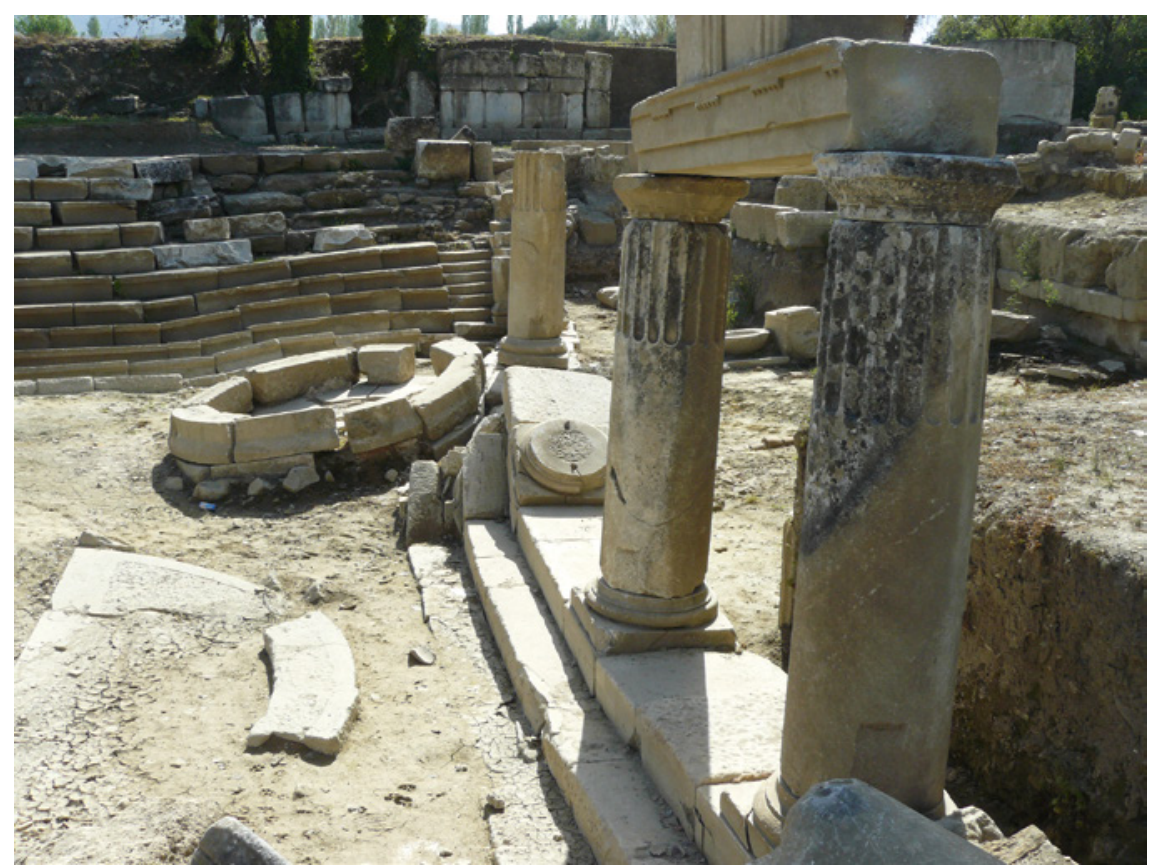

FIGURE 5.11 Lagina. Doric columns with smoothed lower surfaces; the theatron is visible in the background 


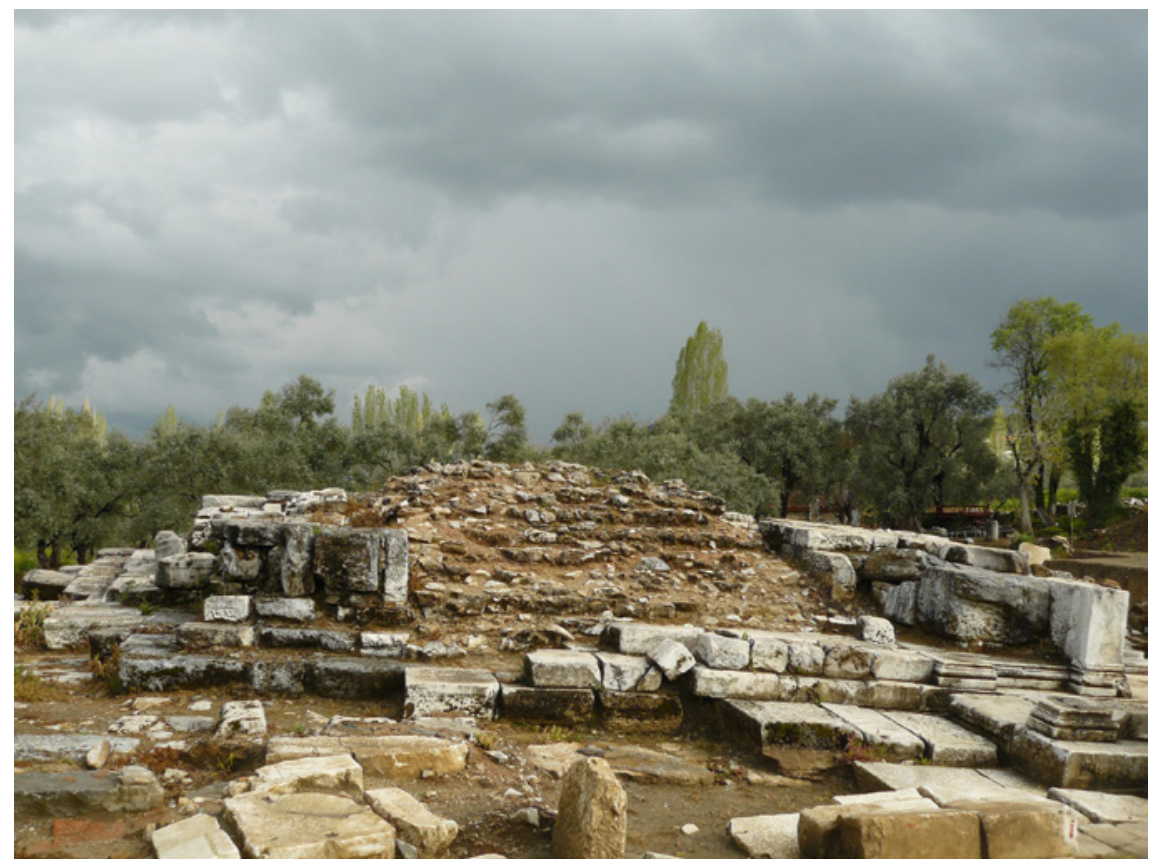

FIGURE 5.12 Lagina. Altar seen from the temple, with marble paving ending in the rubble core supporting the steps

PHOTO AUTHOR 2009

Although the stoa complex now visible is dated to the Augustan era, following the destruction by Labienus (Figures 5.7-5.8, 5.10-5.12), excavations in 2009 revealed a similar configuration from the fourth century BC. ${ }^{112} \mathrm{~A}$ second propylon was discovered in 2011, breaking through the otherwise blank wall of the southeast stoa. ${ }^{113}$ Like the primary propylon, this gateway appears to date from the Augustan era; its unusual design combines Doric capitals with Ionic fluting, and a prostyle porch of three Doric columns that accentuated the double gateway into the temenos. ${ }^{114}$ The porch was entered laterally by steps. Situated across from the open area east of the temple-altar axis, this secondary access may have been connected either with the festival or possibly with other structures or a road outside the temenos to the south. On the opposite side, a third point of access may have been built into the northwest stoa, although

112 Rumscheid (1994), 23; Tirpan et al. (2012), 196-197. Gider (2012), with a plan of the sanctuary on p. 274, Fig. 1 and a reconstruction of the North Stoa on p. 28o, Fig. 19.

113 Büyüközer (2015), with a plan on 68-69 and reconstructions on 72-73.

114 On the Doric architecture at Lagina, Gider (2005). 
this awaits further investigation and publication. ${ }^{115}$ The open space southeast of the propylon must have been filled or blocked since the propylon would otherwise have been pointless - perhaps this was partly occupied by Hekate's sacred grove? ${ }^{116}$

Once inside the sacred space, the visitor arriving through the grand propylon would immediately have noticed the monument for the brothers Menekles and Epainetos, erected in the later first century вс (Figures 5.9, 5.18 and 5.26). ${ }^{117}$ From here one faces the southwest side of the altar, slightly at an angle from the temple, and connected to it by a paved marble path (Figure 5.12). Kinetic linear space was also made tangible inside the sanctuary connecting two distinct places through physical movement. ${ }^{118}$ The altar was also rebuilt under Augustus, and was constructed as a П-shaped colonnaded type; presumably it occupies the place of the older altar, which may explain the unusual orientation, although it may well have shifted during earthquakes. ${ }^{119}$ Cassettes from the ceiling of the altar colonnade, some found in the fill of the later altar, display a wonderfully rich variety of fish, birds, fruit, poppies and other flowers, pine cones, amphoras, human forms and faces, and testify to the importance of fertility and abundance at the shrine. A few even display doubleaxes (Figure 5.13), alluding either to Zeus Labraundos or Karia in general, as at Sinuri. ${ }^{120}$

The complex clearly provided shelter and would have proved useful for several cult activities, including feasting although no formal banqueting rooms were identified. ${ }^{121}$ But most important was the intense sense of enclosure and internal focus that the peripolion provided to the shrine - a regulated and

\footnotetext{
115 Gider (2012).

116 Mentioned in I.Stratonikeia 513, discussed below under Legal Administration; see also Laumonier (1958), 364-365; Tirpan (2008), 451; Carboni (2013), 65-66.

117 I.Stratonikeia 1426 and 1427 (= EA 29 (1997), 85-86, nos. 3-4). Discussed below.

118 Similar to the paved path (in gneiss) between the temple and altar at Mamurt Kale, see Williamson (2014a).

119 The П-shape of the altar echoes earlier sculpted monumental altars as at the Asklepieion on Kos, third century вс, or the altar of Artemis Leukophryene at Magnesia on the Maeander or the monumental altar of Zeus at Pergamon, both from the second century ВC; see also Linfert (1995). Earthquakes are known to have affected the area and two faults appear in the foundation of the altar, Söğü (2019), 262, Fig. 65 and p. 316.

120 At Lagina at least two small cubic stone blocks were found carrying a double-axe. One is a votive altar dedicated to the god Kanebos (I.Stratonikeia $1419=E A 29$ (1997), 103, no. 25, not dated); Kanebos is also known from a Late Classical-Hellenistic inscription from Hyllarima on the sale of priesthoods, $S E G 55$ 1113. The other stone bears no inscription. On the double-axe as a votive, see also above in Chapter 3 , but also Chapter 4 , under $\mathrm{Cult}$ Iconography on the double axe relief at the sanctuary of Sinuri; see also Figures 3.14a-b.

Indicated in I.Stratonikeia 668, see further below on banqueting activities.
} 


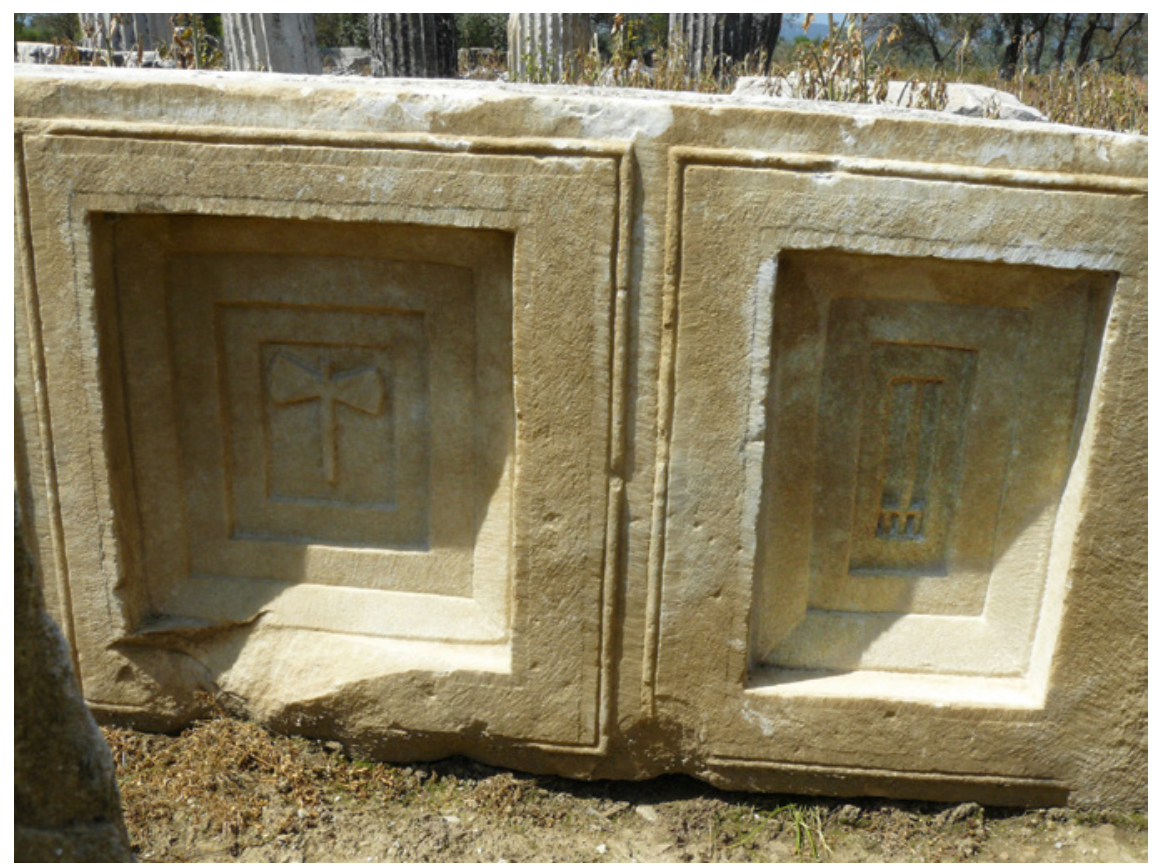

FIGURE 5.13 Lagina. Coffered ceiling fragments, with reliefs of a double-axe and a trident PHOTO AUTHOR 2009

coherent concentric space, more so than at any of the sanctuaries discussed in this study. There would have been a marked contrast between the exterior and the interior of the sanctuary. ${ }^{122}$ Surrounding the interior, the columns of the stoa, with the smooth surfaces of their lower unfluted sections (Figures 5.105.11), created an urban, agora-like setting, with the rhythm of the columns creating a punctuated surface, while the back walls closed off the sanctuary from the external world. ${ }^{123}$ In this sense the sanctuary complex would have resembled a public and especially cosmopolitan space. The only difference

122 A parallel may be found in the sanctuary of Meter Theon at Mamurt Kale, or Pisidian Antioch, see Williamson (2014a) and (in press-a).

123 Columns with non-fluted surfaces on their lower parts were often found in agoras and areas of heavy traffic, perhaps the most well-known example is the Stoa of Attalos in the Athenian agora. Laumonier notes how they also appear in a number of urban Hellenistic sanctuaries, e.g. in Pergamon (Demeter), Magnesia on the Maeander (Artemis Leukophryene), Notion (Athena sanctuary on the acropolis), Teos (Dionysos), Alabanda (Apollo), and Mylasa (Zeus Osogollis); Laumonier (1958), 346-347 n. 1. On form and function in Hellenistic agoras, see Dickenson (2016); Sielhorst (2015). For the compartmentalization of urban space into units articulated by architecture: von Hesberg (199o); Zimmermann (2009), 25-26; and Emme (2013), esp. 225-230 on 'porous' interiors. 
was its location; it seems to have been designed as a suburban annex. ${ }^{24}$ The architecture at the sanctuary would have made it noticeable from a distance, but the bland exterior, relieved only by the entryway on the south and possibly north flank, indicates that its role as landmark was less important than what went on inside.

The unusual southwest wing of the stoa accentuated the internal focus of the complex with its theatron of 11 tiers of seats that lined the entire length, over $100 \mathrm{~m}$, of the inner southwest stoa wing, accessed by steps at either end (visible in Figures 5.10-5.11).125 Allowing for 0.50 m per seat, some 2200 people could have comfortably sat down at the same time, with probably more standing at the top and in the other wings of the stoa. The provision for an audience automatically turned the opposite space before the cella wall of the temple into a podium. Clearly ritual performance at Lagina knew a rich variety, including perhaps reenactments, hymns, crowning victors or bestowing other public honors, besides the sacrifice on the monumental (and theatrical?) altar.

Hekate's temple, near the center of the complex, shows a mixture of traditional and innovative styles and techniques, several of which still puzzle scholars today. The temple faces southeast, and is situated on a shortened stylobate that supported a pseudo-dipteral peripteros of $8 \times 11$ columns $(21.3 \times 28 \mathrm{~m}$ stylobate) in the Corinthian order, an early example of its use on the exterior (Figure 5.14a-c). ${ }^{126}$ This peristyle surrounded an almost square cella, covering an earlier bothros and niche at the back, exactly under the area of the cult statue. ${ }^{127}$ The pronaos is nearly as deep as the cella. The temple lacks an opisthodomos, which by that time was not uncommon on Ionic temples (e.g. the fourth-century Ionic temple of Zeus Labraundos, also the temple of Athena Polias in Priene).

124 Williamson (2013e) on sanctuaries as public and urban space. In the later third century AD, a biotike agora, or 'live market', was part of the sanctuary, adjacent to the southwest wing of the complex, I.Stratonikeia 668, lines 8-10, discussed below under Local Community and Economic Resources. Whether form followed function or function followed form at Lagina, i.e. whether the agora function was already a factor in the Hellenistic design, or came later, is unknown. On sanctuaries as inscribed, and hence cosmopolitan spaces, see Kamphorst (forthcoming).

125 Apparently dedicated by the priest Aristeas, son of Aition of Koranza, in the first century AD, I.Stratonikeia 653 .

126 Tirpan et al. (2012), 184, Fig. 3 shows the plan of the temple. The round temple of Portuna in Rome is dated to the second century BC. On the development of the Corinthian column, initially used exclusively in interiors, see Pollitt (1986), 248-249. Tirpan believes the choice for the Corinthian order as informed by the Seleukid heritage, rather than Roman identity, of the Stratonikeians, Tirpan et al. (2012), 199.

127 Büyüközer (2018) discusses the earlier phases of the temple. 

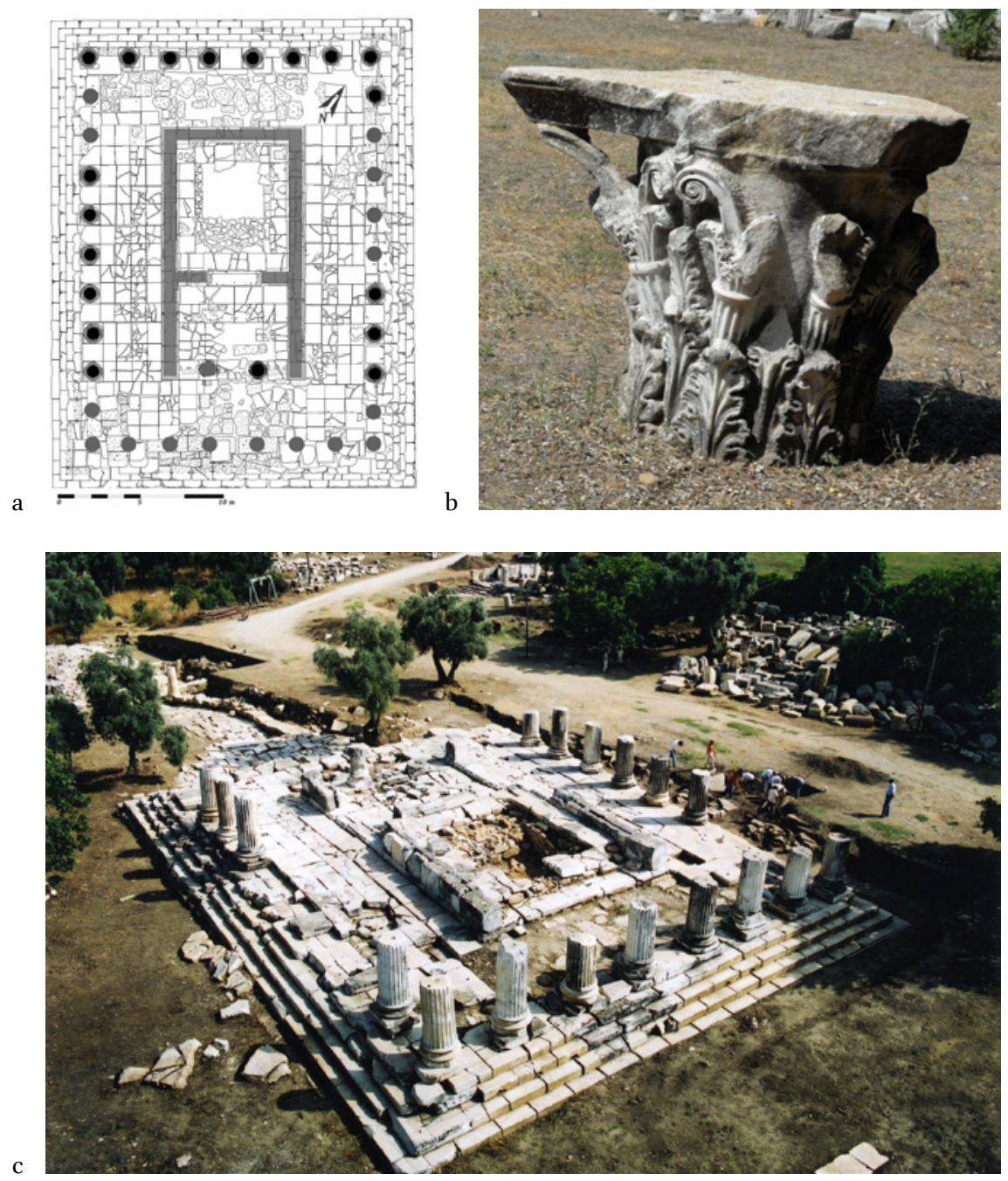

FIGURE 5.14 A-C Lagina. Temple of Hekate. a) Plan, showing $8 \times 13$ Corinthian columns and 2 Ionic columns in antis in the pronaos. (after Tirpan and Sögüt 2007, 401 Resim 1); b) One of the Corinthian capitals from the temple. (photo author 2019) c) Aerial overview from the north

PHOTOS A AND C COURTESY OF PROF. AHMET TIRPAN; PHOTO B AUTHOR 2019

Different scholars have argued for two separate building phases for the temple: the first would be in the early Hellenistic period, close to 300 BC, when the temple simply had two Ionic columns in antis, and a later phase, some time after $200 \mathrm{BC}$, when the order was changed to Corinthian, with the addition of a Corinthian peristyle on the exterior and corresponding Corinthian pilasters 
on the interior. ${ }^{128}$ This suggests an initial construction phase in the context of Koranza, with the later expansions under the aegis of Stratonikeia.

The tympanon was pierced with apertures, similar to other temples in Asia Minor and scholars debate whether this was simply to relieve the weight, as Dinsmoor believed, or to stage an epiphany, as Bammer suggested for Ephesos. ${ }^{129}$ Hekate is 'epiphanic' in at least one of the later inscriptions, and she is depicted in hieratic stance, frontal and detached, in the gigantomachy frieze on the temple, but there are no firm indications of ritual epiphanies. ${ }^{130}$ Concerning the frieze, this is Lagina's central claim to fame in the modern era and has received the most scholarly attention. ${ }^{131}$ This continuous frieze, embellishing the entablature of the peripteros, is divided into four zones that include a gigantomachy on the 'west side' with the epiphanic appearance of Hekate (Figure 5.15), and on the 'east side' the birth of Zeus with Hekate assisting his delivery, allegorical representations on the 'south side', and on the 'north side' a remarkable relief with Amazons and soldiers, with Hekate presiding (Figure 5.16).

The polis of Stratonikeia would in any event have been responsible for the design of the unusual frieze on the entablature of the temple. One of the earliest studies of this frieze was by Schober, ${ }^{132}$ who drew attention to the 'north'

128 Rumscheid (1994), 132-139, argues on stylistic grounds for the two phases, with the second following 13 О ВC; Pedersen (2012), esp. 517, assigns an initial construction phase near 3 оо вс for temple and/or propylon based on the presence of the Karian-Ionian lewis, otherwise known only in the Late Classical and early Hellenistic periods. Pedersen is cautious not to link the date of temple and frieze to political events, instead he more broadly identifies the second phase to the second century $\mathrm{BC}$, as the Corinthian columns show use of the simple lewis that became conventional in this era. See also Trrpan et al. (2012) and now Büyüközer (2018).

129 Reconstruction in Tirpan et al. (2012), 192, Fig. 6. Such apertures are also found in the temples of Artemis in Ephesos and Magnesia on the Maeander, and the temple of Zeus in Aizanoi, discussed in Williamson (2018), 324-325, with references in n. 89; Dinsmoor (1973[1950]), 225, followed for Lagina by Tirpan et al. (2012), on the weight-reduction interpretation; on the epiphany interpretation, Bammer (1972), 10 fig. 6 and 41, fig. 43.

130 I.Stratonikeia 507, discussed further below. On Hekate's epiphany, also Robert (1937), 461-462.

131 Scholars include: Schober (1933); Laumonier (1958); Junghölter (1989); Simon (1993); and especially by Baumeister (2007). See also Herring (2011), who considers the frieze and temple complex in the context of a hybrid Greek-indigenous community, and Carboni (2013), 59-89, in the wider context of cults of Hekate across the Greek world. Karian heroes are further indicated in the roughly contemporary Salmakis inscription from Halikarnassos, Isager (2004).

132 Schober (1933). Perhaps it is because the frieze was studied before the entire temple was excavated that the section above the entrance, showing the birth of Zeus, is called the 'east' frieze, when in reality the entrance faces more to the south-southeast, while the long sides are dubbed 'north' and 'south', but are really more northeast and southwest, 


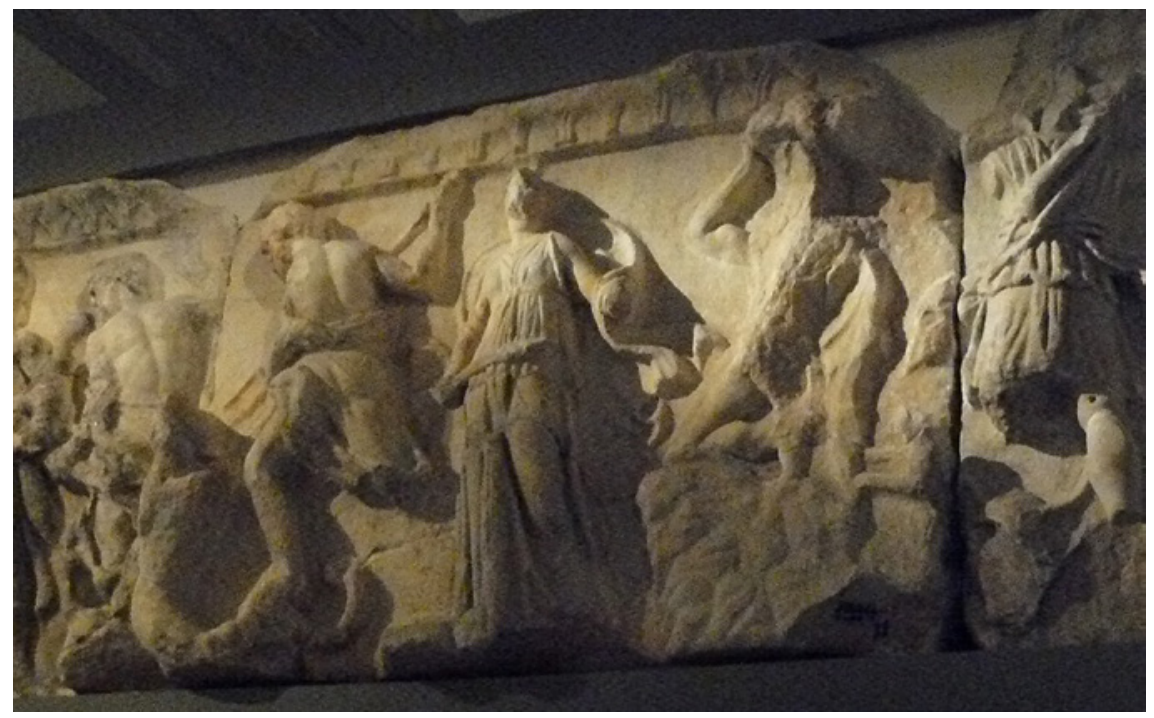

FIGURE 5.15 Lagina. The central part of the 'west' temple frieze, showing Hekate in the midst of a Gigantomachy ISTANBUL ARCHAEOLOGICAL MUSEUM, PHOTO AUTHOR 2009

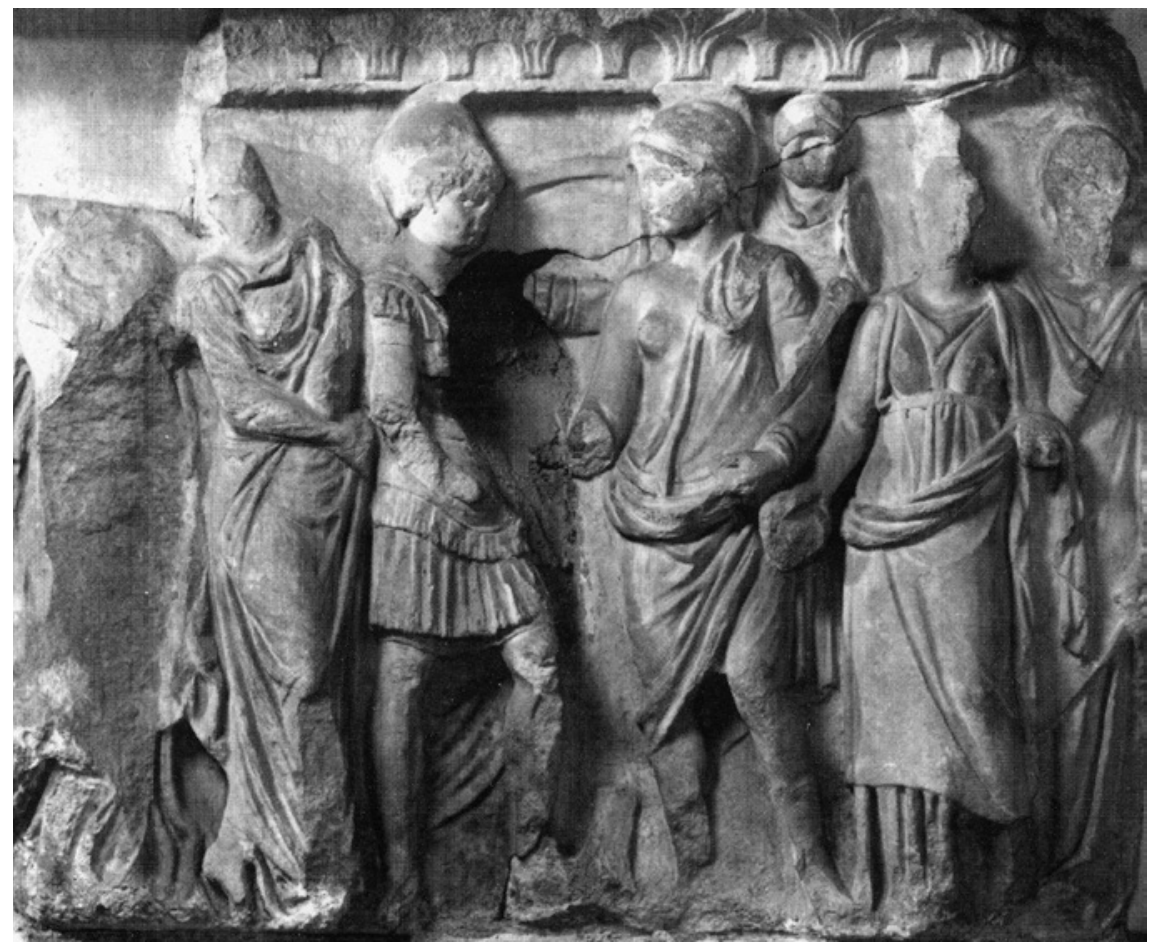

FIGURE 5.16 Lagina. Section of the 'north frieze', showing Amazons and Greek soldiers in amicable relations, with Hekate to the right, holding a phiale PHOTO COURTESY OF PROF. AHMET TIRPAN 
section and its depiction of soldiers and Amazons: these are not engaged in battle as they would be in a regular Amazonomachy, but instead are enjoying cordial relations, shaking hands and clasping shoulders (Figure 5.16).

This anomalous representation has led to much discussion on the interpretations of the frieze and its temporal context, and hence the date of the temple itself. Most of the interpretations view the 'north' frieze as symbolic of a pact with Rome, ${ }^{133}$ with the Amazons representing the Karian cities, and the soldiers representing Rome - the date of the building has thus commonly been linked to one of the events of Roman involvement in Karia, usually either the Aristonikos revolt of $133^{-129}$ вС or the Mithridatic wars of the 8оs вС..$^{134}$ With respect for the various arguments, I will for the purposes of this present study adhere to the findings of Peter Baumeister, who meticulously studied the style, content, and context of the frieze, and proposed a date in the late second century $\mathrm{BC}$, based primarily on stylistic comparisons. ${ }^{135} \mathrm{He}$ observed among others that the uniforms of the soldiers are Greek, not Roman, while the Amazons are more linked to the founding myths of a number of cities in west and northwest Asia Minor. Baumeister thus believes the evocative 'north' frieze is either an historical reference to an alliance between Karia (the soldiers) and some of the cities of west and northwest Asia Minor (the Amazons);

and the opposite end is more northwest than 'west' - see Figure 5.8. However, I will follow the conventional naming for the sake of reference.

133 Laumonier even considers the surrounding figures on the frieze as the 'oath gods' Poseidon, Ares, Aphrodite, and Artemis - who guaranteed the treaty, Laumonier (1958), 351 .

134 Schober (1933) believed the frieze to date after the Aristonikos uprising; Junghölter 1989 connected the temple and frieze to the Mithridatic wars, based on the senatus consultum (I.Stratonikeia 505) inscription carved on the walls of the temple, followed by Rumscheid (1994), 139-140. It goes beyond the scope of this study to discuss all of these views and their ramifications, but for a good review, see Baumeister (2007), 35-40. In the meantime, van Bremen's suggested date between 150 and 13 O ВC (van Bremen (2010)) would roughly coincide with the first coin issues of Stratonikeia, Meadows (2002) Group 1 (see below under Cult Iconography in Urban Contexts). These may have reflected the cult image of Hekate, based on epigraphic comparisons of the orthography of the inscriptions on the temple walls. Van Bremen's caution in linking such a building project with a specific historical event is understandable, "Date and interpretation ... unfortunately have an uncomfortable way of shoring each other up, to no good effect," van Bremen (2010), 502. Nonetheless, festivals and accompanying sacred architecture are often prompted by the celebration of difficult victories.

135 Baumeister (2007), 11-33 and 219-220 on the date of the temple and frieze, with supportive parallels in the similarly 'retrospective' architecture at the pseudo-dipteral temples of Apollo Smintheios in Chryse and Apollo Isotimos in nearby Alabanda, both mid to later second century BC, Baumeister (2007), 154-155. 
alternatively he suggests that it could also be an allegorical depiction of the new paradisiacal age of peace that was made possible by the intervention of Rome during the Aristonikos uprising, and the beginning of the Roman province of Asia. ${ }^{136}$ In either case it seems clear that the military force represented on the frieze is meant to be Karian, rather than Roman.

Baumeister's second interpretation, of a general age of peace, could explain the cosmic presence in the rest of the frieze, with the assembly of Karian gods, heroes, and nature personifications shown on the 'south' side, the rather anemic gigantomachy on the 'west' side with Hekate at the center, and the birth of Zeus, assisted by Hekate, on the 'east' side. ${ }^{137}$ If the iconography of this frieze is a pro-Roman statement, it would be in keeping with Stratonikeia's general disposition towards the superpower. ${ }^{138}$ Stratonikeia had shown nothing but loyalty to Rome since her liberation from Rhodes in $167 / 6$ BC and seemed quite eager to underscore these good relations, as the later installation of the cult for the goddess Thea Romē in Hekate's sanctuary proves. ${ }^{139}$ Yet if the focus were shifted to the 'south' section of the frieze, then one might also view the temple as a very Karian-centered proclamation, perhaps even focused on Stratonikeia with Zeus Karios of Panamara and Hera Teleia taking their enthroned positions in the 'Karian pantheon.' ${ }^{140}$ The allegorical references to natural phenomenon may well have been a way of using the landscape as a symbol for the

${ }_{13} 6$ Baumeister (2007), 'These I' and 'These II', 53-61. The main problem with dating the frieze within the context of the Aristonikos uprising is that the impact which this war actually had on Stratonikeia, or Karia for that matter, is very unclear; Marek (1988), 297-298, sees no reason for Karia to have been involved in the wars at all, nor was it included in the province of Asia until after the Mithridatic wars. Errington observes, however, that Karia was generally pro-Roman after the eviction of Rhodes in $167 \mathrm{BC}$, perhaps lending a great deal of support to Rome during this entire period, Errington (1987).

137 Baumeister (2007), 61-65.

${ }_{13} 8$ The representation of historical events in sacred sculptural programs is complex, e.g. Kuttner (2005), 187. Offering an alternative view, van Bremen (2010), 503, suggests that the frieze has nothing to do with Rome but instead represents the role of Hekate in Karian mythology, and that the 'north' frieze probably indicates a local foundation myth. Both interpretations could be the case, e.g. as with the Pergamon altar, or the Parthenon friezes for that matter, where political realities are framed through mythological narratives. In the absence of further evidence, several hypotheses are plausible.

139 On the cult of Thea Romē see Mellor (1975) and Errington (1987).

140 Baumeister (2007), 36-37 discusses the interpretation of the 'south' frieze. Among the nature allegories and city personifications on the 'south' frieze, the 'Karian pantheon' identified by Baumeister includes an enthroned Hera Teleia (once believed to be Hekate, see Baumeister (2007), 37) and Zeus of Panamara on Block 201 (depicted in Baumeister (2007), Tafel 6-7, figures 3 and 7), and a bare-breasted Aphrodite, armed Athena, Ares, and a young Apollo on Block 202 (Tafel 8, figures 1, 3-5). The sanctuary of Zeus at Panamara, some $10 \mathrm{~km}$ southeast of Stratonikeia, was the other major urban cult of Stratonikeia, 
region of the polis, as discussed in Chapter $2 .{ }^{141}$ In fact, this is the section that faced the audience seated in the theatron of the southwest stoa wing, serving as a backdrop for the ritual performances that took place below. ${ }^{142}$ The 'east' frieze is then interpreted as a Karian 'annexation' of Greek myth, ${ }^{143}$ in a general vision of the natural and cosmic forces as seen through Karian, or more specifically, Stratonikeian eyes.

The frieze represents the official iconographic program of the sanctuary, which Laumonier observes marks the transition between Hellenistic and Roman art. ${ }^{144}$ A second level may literally be found below the frieze, on the krepis and stylobate of the temple, where several outlines of feet are incised (Figure 5.17; with similar 'graffiti' in the propylon). Of course, it is impossible to know for certain how old these less formal markings are, but it indicates the presence of people at the sanctuary, and the desire of people to make their presence known. ${ }^{145}$

In any event, the temple should be seen as a monumental marker of Stratonikeian urban presence in this area of her territory, with the frieze surely

see Chapter 6 below. This frieze would in any event argue for the inclusion of Hera at Panamara by this period, if the Zeus represented here is in fact Zeus of Panamara.

141 'Symbolic shaping' is one of the stages in Paasi's model of building regional identity, Paasi (2009). In this he recognizes the use of landscape as symbol, also referring to Meinig (1979); see Chapter 2.

142 On the use of temples as 'backdrop' for ritual drama, Nielsen (2002), 16. The southwest wing was on the upper side of the slope, making this the natural choice for the location of a theatron; the exact date of this wing is unknown - if the assumed date is Augustan, then it clearly post-dates the temple, and it is unknown whether there was a theatron here in Hellenistic times as well. In any event, at least by the Roman period if not before, the 'south' frieze is the section that people were able to consider the longest, while seated during the ceremonies, whether this was intentional or a coincidence. In this light, it is interesting that this is the only section where Hekate does not appear, but Zeus of Panamara instead, intertwining the two main cults of Stratonikeia even further (see below under Festivals). Also, this is where Riet van Bremen locates the Senatus consultum de Stratonicensibus inscription (I.Stratonikeia 505-507), van Bremen (2010), 493-495, discussed further below.

143 Laumonier (1958), 349; Picard (1933), 401.

144 Laumonier (1958), 353; he also refers to it as an "effort théologico-artistique," p. 349, n. 6.

145 There are other graffiti images as well, including a dog and maybe a cow, but most were pairs of feet. Ahmet Tirpan believes they may be from the later Byzantine period (pers. comm. 16.04.20o9). Feet and footprints on monuments are not uncommon at sanctuaries, possible interpretations are discussed in Dunbabin (1990). See also the four golden

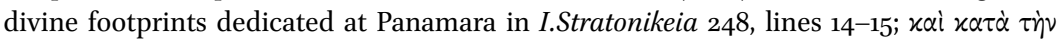

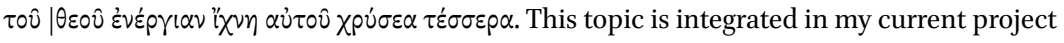
on sanctuaries as multi-scalar hubs of meaning, part of the larger Connecting the Greeks project at the University of Groningen, sponsored by the Netherlands Organisation for Scientific Research (Nwo). 


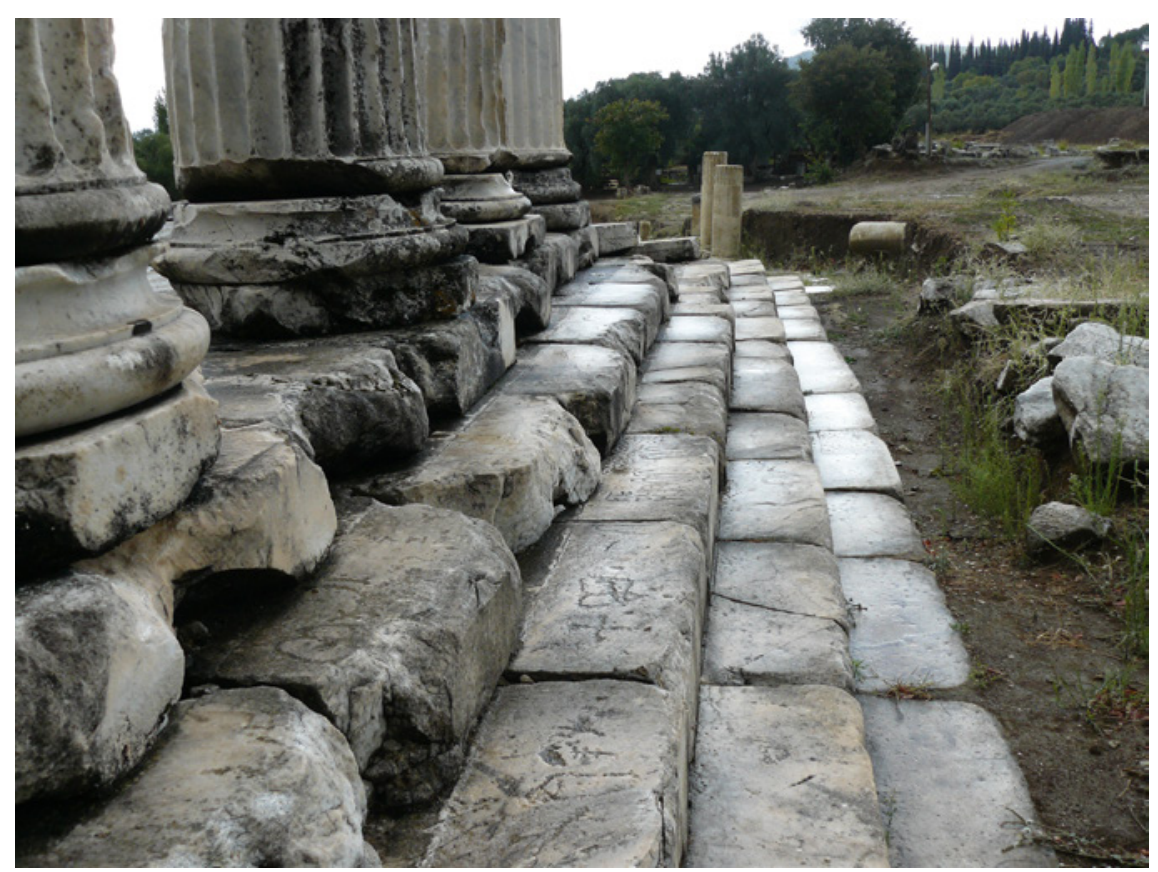

FIGURE 5.17 Lagina. The southwest krepis of the temple. Note the 'graffiti', including several outlines of feet

PHOTO AUTHOR 2011

as an ideological representation of this transformation of physical, political, and ritual space by its depiction of the natural order of the cosmos within a carefully controlled, and thus peaceful, context.

\subsubsection{Public Space - Concentric and Linear}

The temple is situated near the center of the stoa complex and the frieze would have helped to draw the visitor in from the propylon, probably along the altar, in a spiraling motion around the temple. Although the altar was ritually the center of the sanctuary, it actually seems somewhat marginally positioned in the space within the complex. As mentioned above, the architecture of the sanctuary was one of enclosure, ensuring a focus on the interior as a unit, mostly closed off from the outer world. In more ways than one it resembled a Hellenistic agora, marked by the smoothed Doric columns (Figures 5.10, 5.11), with an internal dynamic of its own, in this case accentuated by theatron along the southwest wing.

Within the concentric space at the sanctuary, the altar would have been the prime ritual focus, but the temple itself would have attracted attention, 
drawing visitors around the sides of the temple to 'read' the frieze on the architrave, but also the inscriptions on the temple walls. The Senatus consultum de Stratonicensibus is suggested to have been inscribed on the side opposite the theatron. ${ }^{146}$ This tribune, along the length of the stoa, would have been less suited to mutual interaction a theater 'in the round', but it was surely designed around a common focal point, where everyone could equally observe in the ritual event. In this sense, it created a centripetal concentric space, where a sizable gathering could convene and simultaneously share in the ritual performances, while monitoring each other's reactions at least to a degree. ${ }^{147}$

Except for the sacred road, the concentric space of the sanctuary was largely cut off from the outer world, becoming a separate and distinct zone where time and space took on a very different meaning. Unlike Labraunda, where visual linear space was put to use by emphasizing or even framing sightlines, the views to the outside world at Lagina would mostly have been obscured by the stoa complex, with two important exceptions - the peaks of the Akdağ, rising above modern Turgut and probably ancient Koranza, and the Aladağ, which separated Lagina from Stratonikeia. These mountains may be the key to the unusual orientation of the sanctuary. The temple and complex both follow an unusual southeast orientation (Figure 5.8). Since the conditions of the gentle slope make almost no demands on the layout of the architecture, an explanation must be sought elsewhere. Parallels with other temples of Hekate are lacking, but it is interesting to observe that the propylon, at a near 9o-degree angle from the temple axis, frames the Akdağ (Figure 5.18), while the temple axis aligns with the Aladağ peak (Figure 5.19); I suggest that these two mountains, watching over the sacred way between Lagina and Stratonikeia (Figure 5.20), were instrumental in determining the orientation of the complex (Figure 5.8 and 5.20). ${ }^{148}$ If so, this not only underscored the connection of the sanctuary with the two features visible above the walls of the stoa, but also referenced their role as guardians over the passage between the polis and the shrine. While uncommon, this would befit a goddess of the roads. It would also show how visual linear space was employed to connect the sanctuary to the same visual region as Stratonikeia, which shared the view of these mountains, albeit from the other side.

\footnotetext{
146 Van Bremen (2010), 493-495.

147 On 'inward-facing' circles as the prime means of generating common knowledge, see Chwe (2001), 30-33, further discussed in Chapter 2.

148 The orientation may, however, also be related to astronomical phenomena, such as a lunar cycle; Hekate is typically crowned by a lunar crescent. Ahmet Tirpan discusses the internal visuality from the Augustan propylon, which is higher than the rest of the shrine and offers a good overview, Tirpan (2008), 449-451.
} 


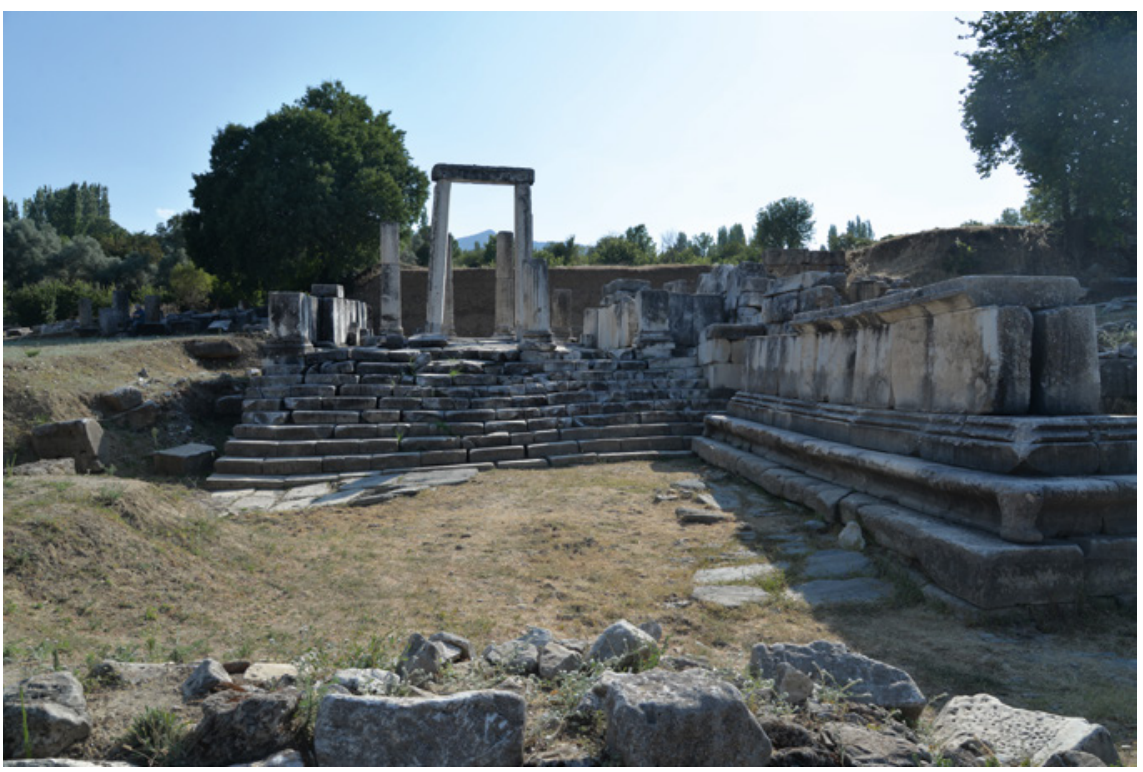

FIGURE 5.18 Lagina. View of the propylon seen from the altar; the Akdağ peak is visible through the doorframe; to the right the monument base for Menekles and Epainetos

PHOTO AUTHOR 2019

Hekate was also the goddess of the gateways, and this may have been one of the reasons why her propylon had such an unusual shape. It vividly marked the entrance to the sanctuary from the sacred road, underscoring the crucial function of the gateway as hinge between sacred and natural or profane areas. It also may have echoed the role of the goddess as mistress of the key, since it would have been the starting point for the festival of the kleidos agoge, where the sacred key was brought from Lagina to Stratonikeia, discussed below. At Stratonikeia it seems that in the imperial period a statue of Hekate was erected by the demos and boule of Stratonikeia next to the bronze doors of the city gates, no doubt on the heavily monumentalized north side of town, where the key would have been received. ${ }^{149}$ The gateways of the sanctuary and the polis thus mirrored each other in a sense, connected by the sacred road, discussed in the next section.

149 Robert (1940), 237-238, in her commentary on I.Stratonikeia 515 in context with I.Stratonikeia 523 and 658 which mention the bronze doors. The Northern City Gate at Stratonikeia, with its monumental fountain, is dated to the second century AD, Mert (2008). 


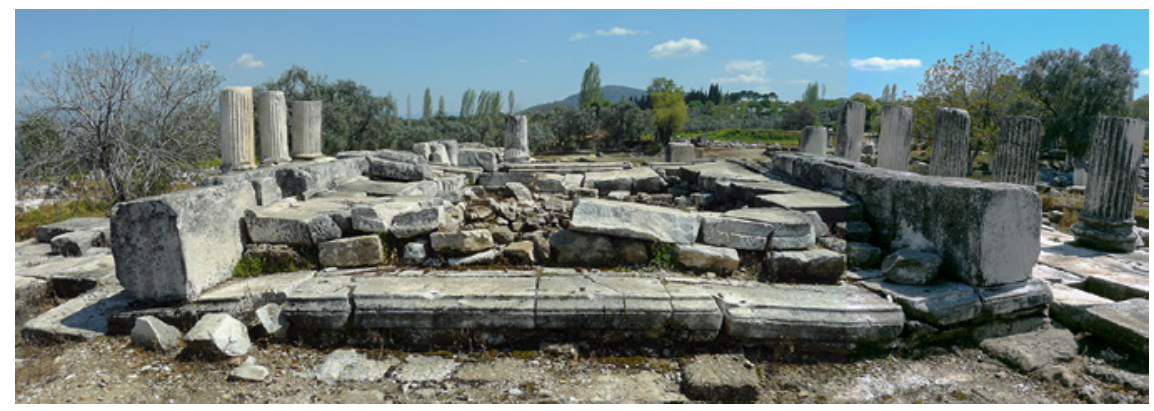

FIGURE 5.19 Lagina. Temple of Hekate looking southeast, with Aladağ peak in the distance PHOTO AUTHOR 2009

\subsubsection{Sacred Road}

Processions became more and more an integral component of festivals in the Hellenistic period, serving to articulate the community while creating a shared focus, emphasized by the sacred target at the end of this kinetic linear space. ${ }^{150}$ The sacred road and the processions that it carried therefore became a critical part of Hekate's festivals from the beginning of the relationship with Stratonikeia. Processions involving country sanctuaries normally move outward from the urban center to the rural sanctuary, where the festivities took place. Yet the festival of Hekate that is known the best is that of the kleidos pompe or kleidos agoge, in which Hekate's sacred key was brought to Stratonikeia in a formal procession, carried by the kleidophoros, a girl or maiden of urban standing. ${ }^{151}$ This was part of the festival of the Hekatesia-Romaia, and its social aspects are discussed in more detail below. The direction of Hekate's processions were thus inverted, and became centripetal rather than centrifugal, as they drew the community out from the countryside and into the town center. ${ }^{152}$ The description of the sacred road will follow the same direction as this route from Lagina to Stratonikeia.

Although strip-mining has eradicated much of the ancient road, enough is left or was already known to reconstruct its path (Figure 5.20); in some places the paved surface may still be seen as the large colorful smooth stones, lined with smaller stones at the edges (Figure 5.21). Several sections of it have been

\footnotetext{
$15^{\circ}$ Discussed in Chapter 2; see also Chaniotis (1995), 158-16o and (2013); Graf (1996); Chankowski (2005).

$15^{1}$ These festivals are discussed below in connection with the Hekatesia; see also Nilsson (1995 [1906]), 400-401. For a reconstruction of the processional experience within the sanctuary in the imperial period, Herring (2020).

$15^{2}$ Graf (1996), 57-59. It is likely that the processions went both ways, yet the emphasis of the kleidos agoge was certainly on the town center.
} 


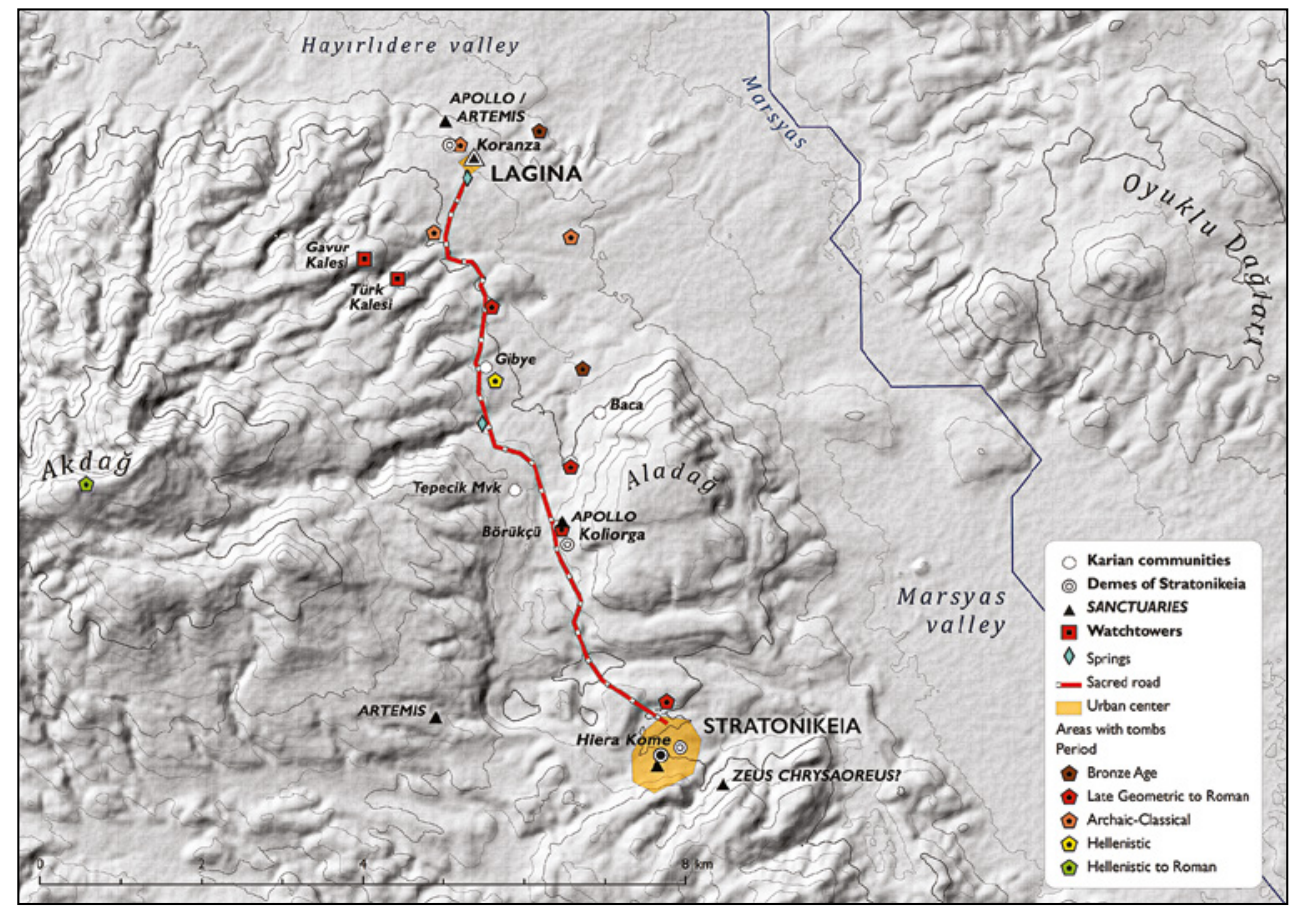

FIGURE 5.20 Map of the sacred road between Stratonikeia and Lagina. Trajectory after Söğüt (2012), Map 1

found between Stratonikeia and Lagina, showing that it largely corresponds with the road used until recently to connect Turgut and Eskihisar. ${ }^{153}$ Thick sediment has covered much of the road near the propylon of the sanctuary of Hekate at Lagina, but the processional route may still generally be traced. The kleidos pompe would certainly have first passed the large round water reservoir, roughly 200 meters to the south (Figure 5.22). This spring-fed reservoir, roughly 10 meters across, stems from the Late Hellenistic or early imperial period, and is interpreted as a sacred pool. ${ }^{154}$ Purification rituals may well have taken place here and the several inscriptions and monumental size certainly point to its public function. ${ }^{155}$

153 On the sacred road, its pavement and its course, see Tirpan and Söğüt (2005a), 52-54 and 71; Söğüt (2012), 555 and Figs. 1 and 9, and Harita 1 for a map of the course of the sacred road; Hild (2014), 45-46, also on the signs of graffiti left by pilgrims at the church later built at Lagina.

154 The pool was discovered during cleaning activities in 1994, Tirpan (1995), 214-215.

155 The inscriptions are published in I.Stratonikeia 1401 and 1402 (= EA 25 (1995), 83-86 nos. 1 and 2). I.Stratonikeia 1401 is restored as a dedication to Zeus Panamaros, based on the 


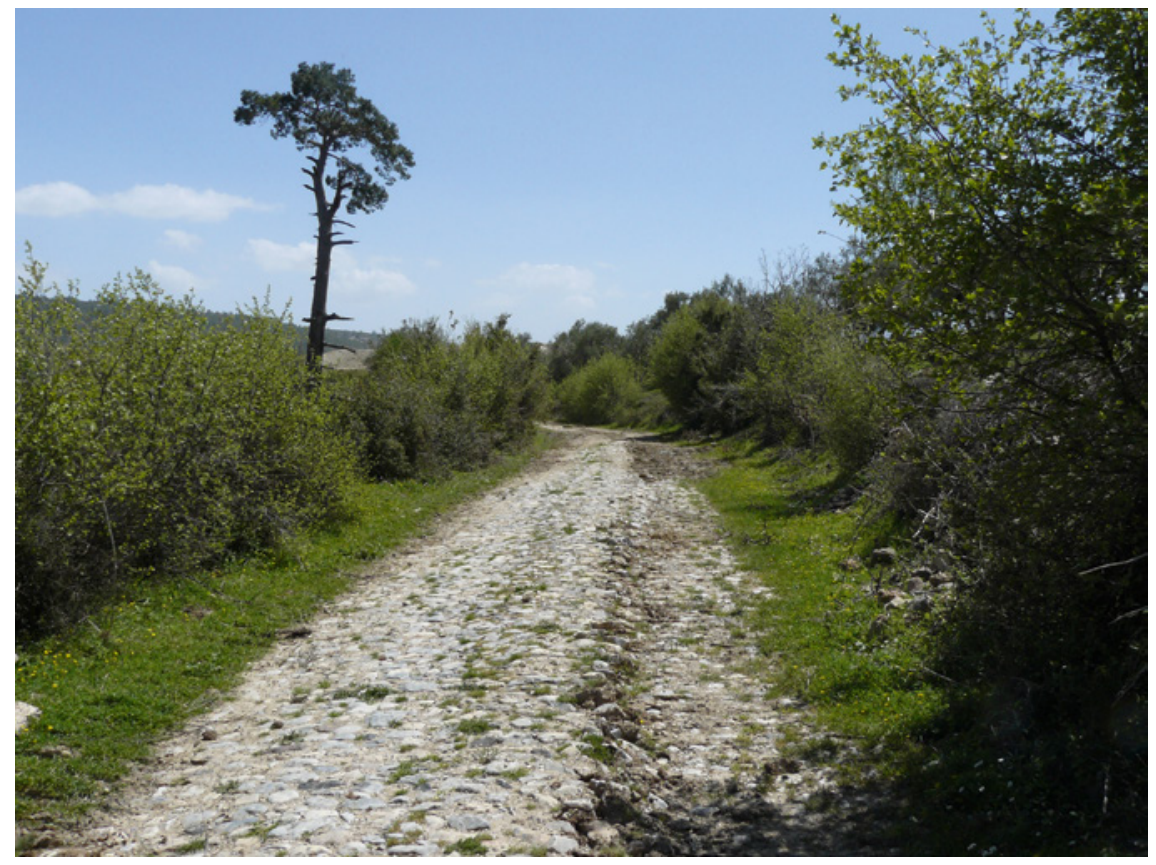

FIGURE 5.21 Sacred road to Lagina, south of Yeşilbağilar Pното AUTHOR 2009

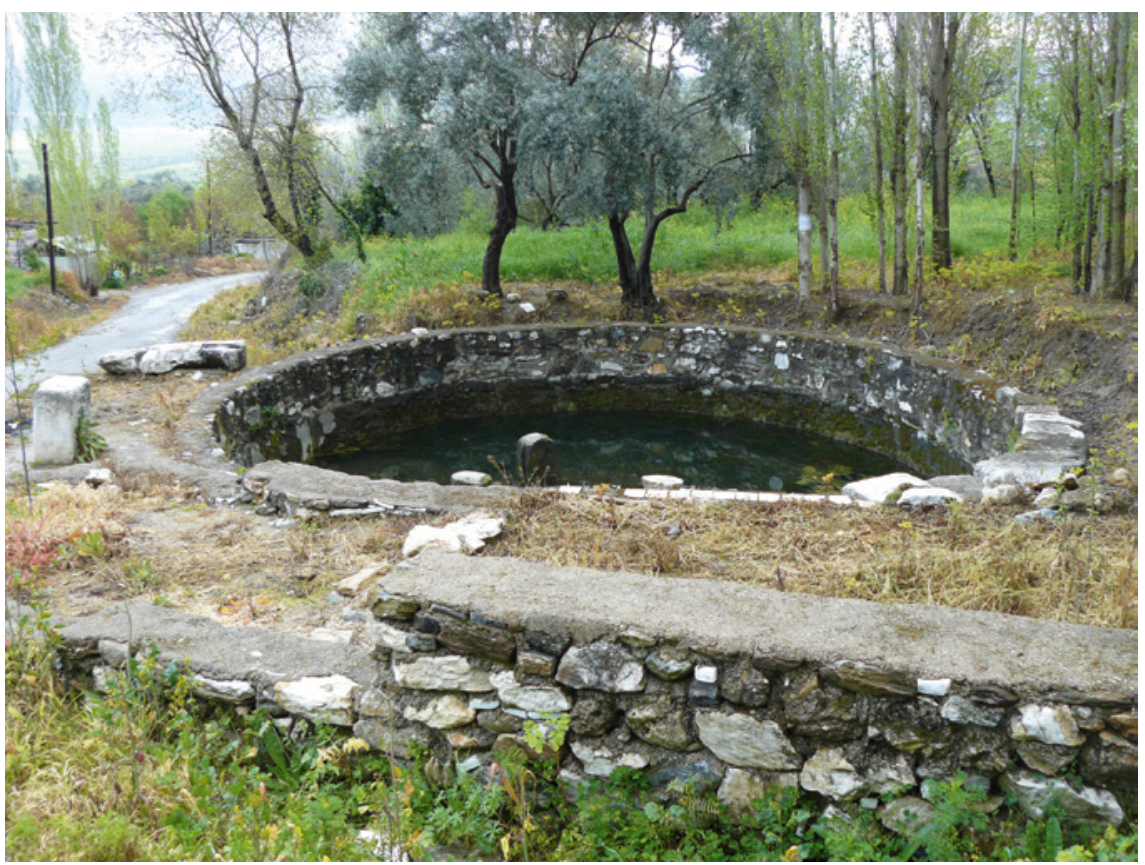

FIGURE 5.22 Lagina. 'Sacred pool' or spring-fed reservoir near the sacred road PHOTO AUTHOR 2009 
The procession would then continue southwest, roughly along the ArchaicClassical tombs of Emirler; to the southwest were two watchtowers, from the Hellenistic and later Roman period, controlling both the northern part of the territory as well as this road and the traffic it carried. ${ }^{156}$ Further to the south, are some Late Geometric graves at Bozukbağ, with more graves, this time Hellenistic, near Yeşilbağcllar (Gibye). South of Yeşilbağcllar is an edified natural spring with material dating from the Archaic period, indicating the use of this road long before the foundation of Stratonikeia. ${ }^{157}$ This spring marks a gentle bend in the road to the southeast, passing Beybağı, occupied from the Late Geometric to Roman times with a peak in the Classical period; in the early Roman period the road appears to have been diverted around a field. ${ }^{158}$ Roughly a half kilometer to the south, along a wadi at Börükçü, is another major settlement which has been identified as Koliorga, a deme which was once a polis in its own right; workshops and tombs line the road with a shrine ('megaron') to Apollo nearby. ${ }^{159}$ This settlement seems to have diminished some after the second century $\mathrm{BC}$, although there are a few tombs from the later Hellenistic and Roman periods. ${ }^{160}$ From here the road passed further south through the valley between the Akdağ and the Aladağ peaks north of Stratonikeia and continued, tomb-lined, to the north gate of town (Figure 5.23). This would surely have been a momentous leg of the journey since Hekate is the goddess who watches not only over the roads and the city gates, but also the transition to the underworld. ${ }^{161}$ There were many reasons for the polis to erect a statue of the goddess at the north gate with its adjacent necropolis; her key may have opened other doors besides the city gates, such as those to life and death.

masculine superlatives typically associated with him. Van Bremen 2003 however, argues that the office of priesthood at Panamara was not for life, which this inscription mentions.

${ }_{15} 6$ Türk Kalesi is from the Hellenistic period, Gavur Kalesi is late Roman, see Tirpan and Söğüt (2005a), 6o.

157 Tirpan and Söğüt (2006), 606.

$15^{8}$ Tirpan and Söğüt (2007b), 398.

159 Aydaş (2006), on the identification of Börükçü as Koliorga. The settlement at Börükçü, between Stratonikeia and Lagina, may have undergone a decline in the Hellenistic period, where over 100 graves were excavated, only a few of which were from the Hellenistic and Roman periods - most were Archaic-Classical: see Tirpan and Söğüt (2004), (2005b), (2006), (2007b), and Söğüt (2012).

16o On the period of activity at Börükçü: Trrpan and Söğüt (2004), 38o and (2006), 6o5-6o6.

161 Nilsson (1995 [1906]), 400-401; Johnston (1999), 206, although she does not address the role of Stratonikeia in Hekate's cult at Lagina. 


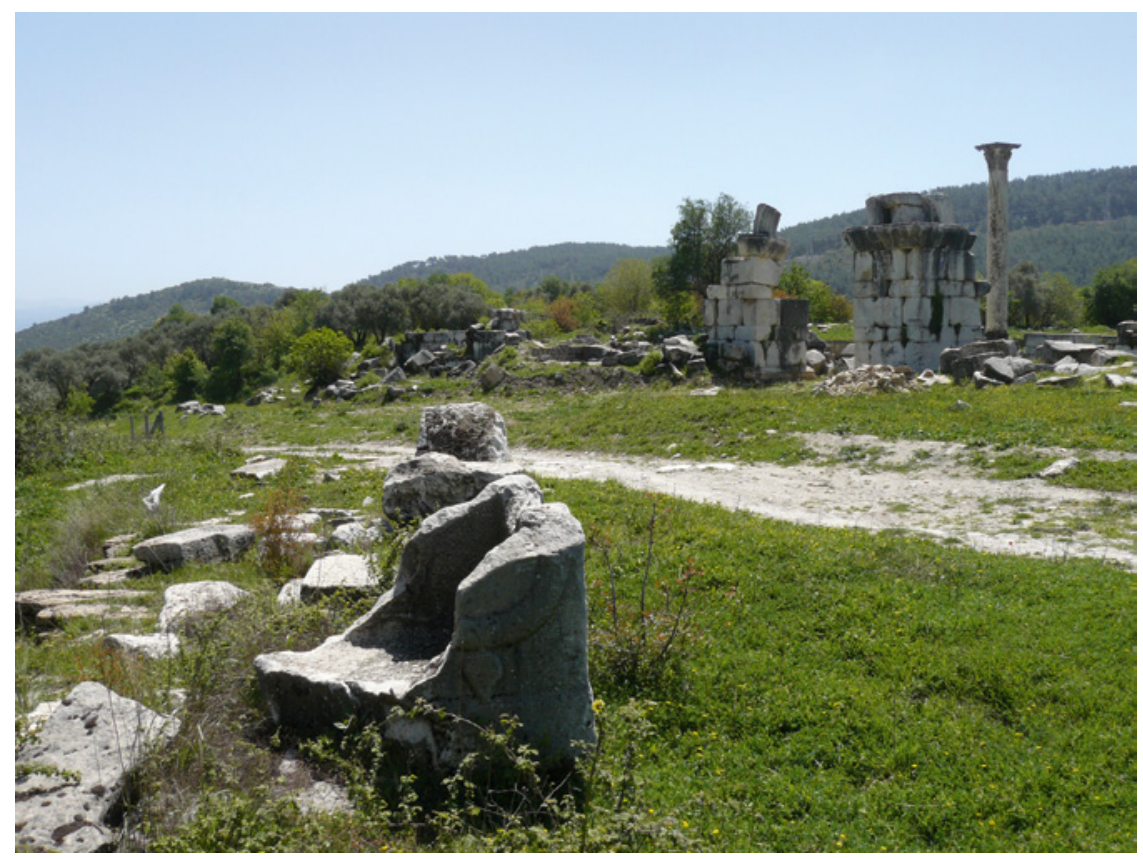

FIGURE 5.23 The North Gate of Stratonikeia, seen from the northwest; the archway is from the later second century AD. Part of the sacred road is visible to the left, next to the sarcophagus PHOTO AUTHOR 2008

Keeping the goddess of Lagina here, close to town, via her statue surely guaranteed her continued vigilance over the living and the dead. ${ }^{162}$

The sacred way was already an important access route between Koranza and the other communities in the area long before its role as a processional route to Lagina. It seems that with the rise of Stratonikeia, settlement activity along the road dwindled. ${ }^{163}$ Although this is a tentative conclusion, it may well correlate with the absorption of the once independent communities into the new polis, discussed above, and the general lure of the urban center with its attractions and enterprises. The processional route however, continued to draw the citizen population across this road, and the passage along the various settlements, local workshops and especially the tombs, must still have formed a kinetic axis for the community, connecting its past with its present. Besides

162 Stratonikeia apparently erected a statue for Hekate at the gates of town in the Roman period - the actual statue is unknown; see Robert (1940), discussed above.

163 Based on the quantities and chronologies of the material from Börükçü, Trrpan and Söğüt (2004) and (2006). 
the pure necessity of transporting Hekate's key to town, the procession was possibly a kind of re-enactment of the formation of the polis, beginning in the 'ancient' town of Koranza and ending in 'modern' Stratonikeia, with some of the older communities, especially the settlement at Börükçü, but also the individual tombs of ancestors, in between. ${ }^{164}$ Rescue archaeology has in any event clearly shown that between the two poles was a vibrant 'spatial continuum' that extended across the different communities, their sanctuaries, tombs, but also their farms and fields (Figure 5.19). ${ }^{165}$

In sum, Lagina was obviously a well-known landmark, as Strabo's guide of Karian distances indicates. ${ }^{166}$ Location was important, but the key to the sanctuary was on the inside. The blank walls of the stoas largely closed off the shrine from the outer world, while the unusual propylon served as a transitional hinge, guiding the visitor from the profane world down into the sacred world of Hekate, but also the urban world of Stratonikeia. Within, nearly a hectare of land was circumscribed by stoas in the Doric order, providing an urban space with the monumental altar and innovative Corinthian temple at its center. The series of friezes on the architrave would have invited circular movement around the temple in order to appreciate the goddess' role in helping at the birth of Zeus, suddenly appearing in the gigantomachy, and presiding over an encounter between Amazons and Greeks. Although Hekate is absent from the paradisiacal relief of Karian gods, city personifications, and nature allegories, this was the section opposite the theatron and was probably seen the most. This seating arrangement along the southwest stoa indicates the theatrical setting of the complex, a concentric space with the temple and altar as focus. ${ }^{167}$ The inner world of Hekate was further connected to the outer landscape through sightlines from the temple to the Aladağ, and the propylon to the Akdağ, the two mountains that framed the sacred road to Stratonikeia. The environment was thus woven into ritual through visual and kinetic linear space, as worshipers traversed the distance from the city to the sanctuary and back again. The

164 Similar to Laumonier (1958), 234-235: "Les cultes de Lagina et de Panamara durent être dès ce moment rattachés à ville par des fêtes annuelles, comportant avant tout une procession qui perpétuait le souvenir de la première entrée des dieux dans la nouvelle ville et leur retour dans les sanctuaires de la campagne et la montagne." Laumonier, however, believes that Lagina and Panamara were both connected to Stratonikeia from the start in a centralized act of Hellenization, ingesting, as it were, the local cults; the idea of a gradual incorporation of the surrounding communities was developed only later by Şahin (1976), Debord (1994), and van Bremen (200o), discussed above at the beginning of this section. See also below, Chapters 5 and 6.

165 On the 'spatial continuum' see Polinskaya (2006), discussed in Chapter 2.

166 Strabo 14.2.29, quoted above.

167 On cultic theaters and ritual drama, Nielsen (2002). 
processions from Lagina, near the northern border of Stratonikeian territory, down the ancient road and into town must have felt like a re-enactment of the development of Stratonikeia, as the older surrounding communities through which they passed had been drawn into the orbit of the polis. In any event it would have expanded the visual region of polis to include that of the sanctuary. The urban setting at the country shrine and the communal processions both fixed the public focus on Stratonikeia itself; Hekate's ritual space was certainly a factor in the 'territorial shaping' of the rising polis. ${ }^{168}$

\subsection{Ritual Performance at Lagina}

Ritual performances inherently provide a shared communal focus and festivals were thus a ready means of creating a bond between sanctuary and polis. Processions were literally the vehicle of festivals, connecting the urban center and the distant sanctuary with the intervening landscape while socially articulating the community en route. As mentioned above, the procession of the key, or kleidos pompe, took place within the context of the annual festival, the kleidos agoge. This festival was one of the ones which served to bind the sanctuary to the city. This section discusses how Hekate's festivals served to set the focus of the community, both local but also international, on Stratonikeia, and how the ritual actions of banqueting and competition reinforced this.

\subsubsection{Festivals}

The investment in the sanctuary in the second century вС proves that Lagina was a monumental cult place for Stratonikeia; large quantities of Hellenistic ceramics were recovered at the site, including loomweights but also unguentaria as at Labraunda. Interpretations of the ritual use of the shrine will no doubt require revision once the ceramics are published. ${ }^{169}$

As it now stands, inscriptions from the first century and later, especially in the Roman period, are our most vocal source of information on the details of Hekate's rituals and festivals. By this period there were several different festivals for the goddess, occurring both in the sanctuary but also in town. Laumonier identifies, for example, the Triakades as a festival held on the 3 oth

\footnotetext{
168 See Paasi (2009) on 'territorial shaping' as the initial phase in defining the identity of a region, discussed above in Chapter 2.

169 Boysal (1993) mentions the large quantity of Hellenistic material found at Lagina, probably from the temple area. On the loomweights, Tırpan and Söğüt (2007a) and (2008). The unguentaria are mentioned in Tirpan (1997) (found between the propylon and the stoa); Tirpan and Söğüt (2000) (several found below the temple floor); also Tirpan and Söğüt (2007a). There was also a settlement at Lagina, discussed below, so these could have had a domestic rather than ritual origin.
} 
of each month, coinciding with the lunar cycle, and the Genethlia, connected with the day of birth of the goddess; during this festival priests would distribute gifts of money and oil among the population, very similar to the practices at Panamara during the festivals for Zeus and Hera. ${ }^{170}$ In this way the cult of Hekate must have played an important role in the personal economic lives of the Stratonikeians, at least by the Roman period. The intrinsic relationship between the goddess and the urban population, however, was established in the Hellenistic period, as discussed above. While major urban festivals were obviously the reason behind the grand architectural program of the second century BC, two important festivals are known to have been developed in the Hellenistic period: the kleidos agoge and the Hekatesia. Each of these bound the remote sanctuary to the city, but in very different ways.

The kleidos agoge was the main festival at Lagina, often referred to as the 'general gathering' (panegyris), the 'sacred month' (hieromenia), or more commonly just the 'festival' (heorte) or 'festival days of the goddess.'.171 It lasted for several days and included feasting and perhaps games, but the climactic event was the kleidos pompe, the procession of Hekate's key as it was brought from Lagina to Stratonikeia. ${ }^{172}$ As mentioned above, the exact nature of this key and what it unlocked is uncertain, possibly to the key to the temple, the gates of the city, the key to life and death, a symbol of priestly authority or probably a combination of overlapping meanings. ${ }^{173}$ The earliest mention of the key is in an elegiac text set up in the second or first century BC by a

170 Laumonier (1958), 393-397 the gifts are listed in the accomplishments of priests of the sanctuary as their term came to an end (over 100 of such inscriptions were found, roughly I.Stratonikeia $623-706,714-739,1438$ ); the gifts of money, but also oil, were also typical of the cult of Zeus Panamaros; this aspect is discussed in more detail below, under Administration and Priesthoods, and in Chapter 6 on Panamara.

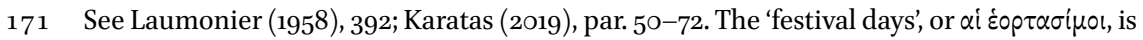
the most frequent, appearing in I.Stratonikeia 530 (lines 7-8), 668 (line 4), 682 (lines 7-8), 685 (line 8), 705 (lines 8-9), and 735 (line 5). I.Stratonikeia 663, lines 9-10 speak of 'the

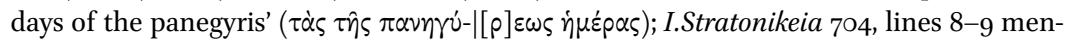
tions the 'the days of the sacred month (and) the the key-bringing of the goddess' ( $\tau \dot{\alpha} \varsigma$

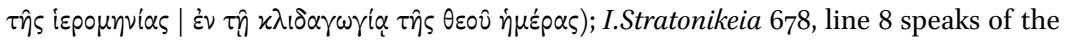

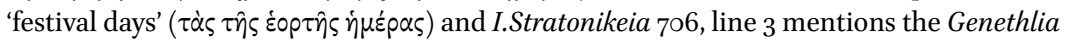

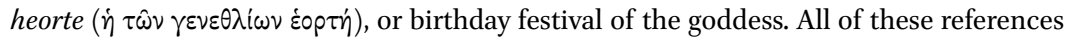
are from the imperial period.

172 The kleidos pompe is mentioned for example in I.Stratonikeia 1048 II.2, p. 34 (fragment), and takes place 'in town' ( $\dot{\varepsilon} \nu \tau \hat{\eta} \pi \dot{\lambda} \lambda \varepsilon \iota)$ as in I.Stratonikeia 701 , line 8; it is sometimes called

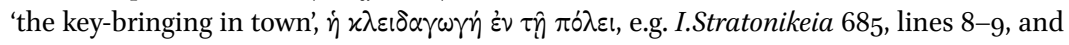
as $\dot{\eta} \tau \hat{\eta} \varsigma x \lambda \varepsilon เ \delta o ́ \varsigma ~ \alpha \gamma \gamma \omega \gamma$ in I.Stratonikeia 735, lines 3-4.

173 See above, also Nilsson (1995 [1906]), 400-401; Laumonier (1958), 398; Kraus (1960), 48-50; Johnston (1990), 41-42; Karatas (2019). 
priestly couple who made their daughter 'Klodiane, a keybearer, dear child, carrying the key in her tender hands' ${ }^{174}$ Klodiane may have been one of the first in a long line of kleidophoroi, girls or maidens who carried Hekate's sacred key during the procession, presumably along the entire eight kilometers from Lagina to Stratonikeia. ${ }^{175}$ The position of kleidophoros was usually fulfilled by the daughter of the priest or priestly couple who served Hekate in that year; she could be accompanied by her brother, the parapompos or kosmophoros. ${ }^{176}$ Being the kleidophoros brought not only honors but also prestige, and it seems that one retained the title for life. This is the case with Triphaina, who later in life, as priestess at Panamara, was referred to as 'daughter of the city and Hekate's kleidophoros.' ${ }^{177}$ In bringing the populace out to the sanctuary and back again, these processions were thus an affirmation of Stratonikeian society, while in their celebration of the elite, they were also an affirmation of its social stratification. ${ }^{178}$

Although there presumably was a corresponding procession out towards the sanctuary, it is especially the movement into town that is interesting; the community was not only assembled at the sanctuary, but was also collectively drawn in across the countryside along the sacred road towards the urban center. ${ }^{179}$ As mentioned above, this may have been a re-enactment of the unification of the religious and administrative centers with the surrounding countryside (also the economic base), creating at the same time a tight

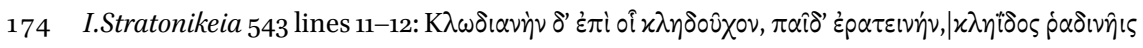

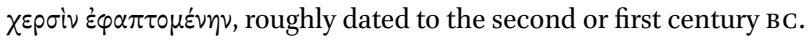

175 I.Stratonikeia $538-543,676,683,690,701,707-713$ either mention the role of kleidophoros, or honor the girl or woman who had assumed that role; these inscriptions continue into the second or third centuries AD.

176 At least on two occasions, I.Stratonikeia 683 and 69o, both from the imperial period.

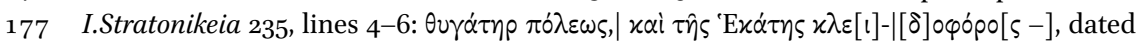
to the first half of the second century AD. Other references to adult women, often priestesses, who had been Hekate's kleidophoros include I.Stratonikeia 17, 256, 326, 327, 1028, and 1048.

178 E.g. Chaniotis (1995), 16o "die Prozession ist das Spiegelbild der polis;" also with political overtones, Chaniotis (2013). Also Chankowski (2005) on the emphasis on harmony and order, and Viviers (2010) on processions, elite display and social hierarchy.

179 Laumonier (1958), 398. On the importance of the direction of the procession, see esp. Graf (1996), 57-59, who discusses 'centripetal' processions, but mostly within the perimeters of the urban center; he juxtaposes this with 'centrifugal' processions, which bring the urban population to out to the rural and peripheral cults. While his discussion is underpinned with structuralist ideas on oppositions such as urban-rural and civilized-wild which simply do not apply in the context of Stratonikeia, given its history and territorial make-up, yet the observation of the need to draw the remote cult of a major deity into town is very useful in this context; see Chapter 2. 
and harmonious relationship in the polis with its territory. ${ }^{180}$ The centripetal direction in this case is crucial, since bringing the cult into town was a way of validating Stratonikeia's role in the territory, while physically ensuring the young polis as the main focus of the entire community.

The kleidos agoge may have been part of the Hekatesia that Strabo apparently refers to as drawing 'great festal assemblies every year.' ${ }^{181}$ Yet an even greater festival would be the Hekatesia-Romaia. This was celebrated after the Mithridatic wars of the $8 \mathrm{os} \mathrm{BC}$, when Stratonikeia received the recognition of asylia (inviolability) by Sulla and the Senate of Rome, as publicly declared in the Senatus consultum of 81 BC posted on the temple walls at Lagina. ${ }^{182}$ Stratonikeia responded by establishing a joint festival for Romē Thea Euergetes (Beneficent Goddess) and Hekate Soteira Epiphaneia (Manifest Savior). ${ }^{183}$ Combining the worship of Hekate, who gave the people of Stratonikeia hope during the hardships they endured under Mithridates VI, with the personification of Rome who brought them deliverance, must have seemed like a logical and natural following step to the Stratonikeians in their relationship with the superpower. ${ }^{184}$ At the same time it was the religious expression of a political reality.

The celebration of the union of these goddesses was not just for the people of Stratonikeia; a penteteria, or quadrennial festival, was to be held that included games. The first reference to this is in an inscription immediately following the Senatus consultum that calls for a list of the names of all the 'cities, kings and rulers', who acknowledge the asylia of the sanctuary and participate in the contests, to be inscribed at the sanctuary. ${ }^{185}$ At least 57 cities responded, voicing their recognition of the asylia, the festivals, and the games (Figure 5.25,

180 Laumonier (1958), 234-235 goes farther in seeing the centripetal procession of Hekate and Zeus Panamaros as "perpétuait le souvenir de la première entrée des dieux dans la nouvelle ville."

181 Strabo 14.2.25, quoted at the beginning of this chapter. Laumonier (1958), 36o, n. 1 believes the Hekatesia was distinguished from the Hekatesia-Romaia through an inscription from Kos (second part of the first century BC) in which it is simply called the 'Hekatesia in Stratonikeia', Iscr.Cos EV 203 (= Syll. ${ }^{3}$ 1066). However, this may have been a shortened reference to the festival.

182 I.Stratonikeia 5 5, dated to $81 \mathrm{BC}$.

183 I.Stratonikeia 507 , see above. A later imperial dedication to Hekate at Lagina refers to athletic victories in the 'Hekatesia and Kaisereia and Romaia', I.Stratonikeia 547, lines 4-5, van Nijf and van Dijk (2020). On the cult of Rome in Asia Minor, see esp. Mellor (1975), Errington (1987), and Chaniotis (2005).

184 Turner (1984) on the relationship between crisis, liminality, and ritual performance.

185 I.Stratonikeia 507, discussed further below under Games and Scope and Network. 


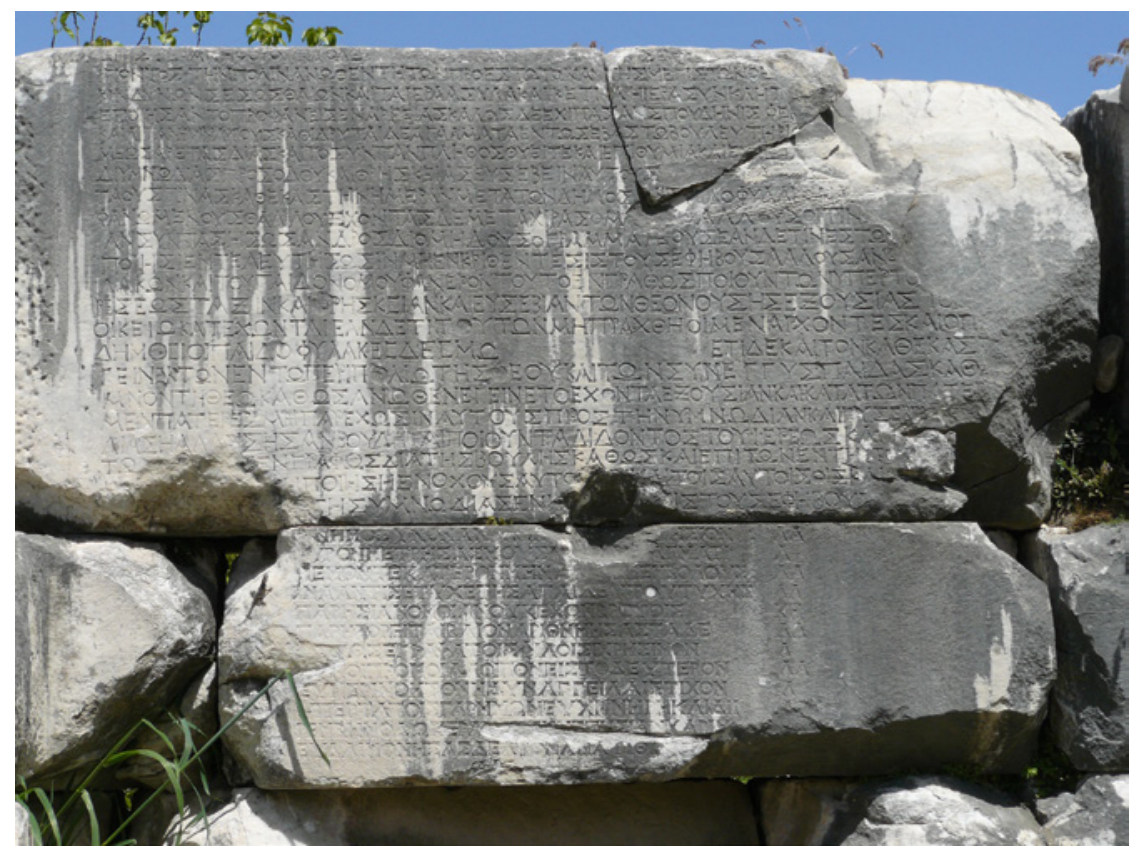

FIGURE 5.24 Section of the Hymnode inscription on the wall of the bouleuterion, I.Stratonikeia 1101. Instructions for the hymnodes during the festivals of Zeus Panamaros and Hekate, third century AD PHOTO AUTHOR 2008

below). ${ }^{186}$ These festivals thus directed the focus of the local and wider community towards Stratonikeia - the Hekatesia-Romaia was an indirect celebration of the position of the relatively young polis as a global player in the wider Greek world, while the kleidos agoge literally brought the key of the cult into the heart of the town, probably to the bouleuterion. ${ }^{187}$ A decree from the later imperial period was inscribed in this building which regulates the hymnodes at the festivals of both Hekate and Zeus (Figure 5.24). ${ }^{188}$ This inscription calls for a choir of 30 ephebes to sing hymns, which were to be written by the secretary of the boule (who happens to be the same person proposing the decree),

186 The significance of this is discussed below in the section on Urban Mediatization.

187 Laumonier (1958), 388 mentions an altar dedicated in the third century AD at the bouleuterion by M. Sempronius Clemens, with statues to Zeus Panamaros, Hekate, Artemis, Asklepios and Hygieia.

188 I.Stratonikeia 1101, proposed by Sosandros, secretary of the boule, widely dated to the later second century AD. The wider ramifications of this inscription are discussed in Chaniotis (2003), 186-189. On hymns and 'singing for the gods' in Archaic and Classical Greece, see Kowalzig (2007b). 
to both Hekate and Zeus Panamaros out of gratitude to both gods for their continuous vigilance over the city. ${ }^{189}$ Chaniotis observes the importance given to the aesthetics, both visually and audibly, of this ritual performance which was to be carried out in the center of town all day long during the festivals. ${ }^{190}$ Although this inscription is much later than the period under examination here, it is significant that it aims to follow, or even revive (or reinvent?) an old tradition, ${ }^{191}$ not only out of piety for the gods, but also to educate the young on proper ritual behavior. ${ }^{192}$ By involving the youth this inscription shows how ritual behavior was a normative process, but especially how it served to create a unifying focus for the public, including the gods.

Although it is otherwise seldom explicitly mentioned, music would have been a major component of the festivals and there are even a few indications for musical competitions during the Hekatesia-Romaia in the Hellenistic

189 Hekate's epiklesis 'Soteira' first appears in the first century BC, I.Stratonikeia 507 and 510, and is probably related to the Mithridatic wars. Some 40 years later Zeus Panamaros protected the city during the attacks of Labienus, see below in Chapter 6 .

190 Chaniotis (2003), 188, who observes the staging directions given in lines 7-10, which he summarizes as follows: "The performance was to take place every morning; thirty young boys, dressed in white, with wreaths and branches in their hands, were to come in a procession led by the paidonos and paidophylakes to the bouleuterion; there, they were to stand in front of the statues of Hekate and Zeus; a herald would accompany them, obviously in order to call for the cultic silence and to say the prayer; a kithara player would provide the musical accompaniment." Although this takes place in the imperial period, he observes how staging directions had become a general concern in Hellenistic inscriptions as well; see also Chaniotis (2013).

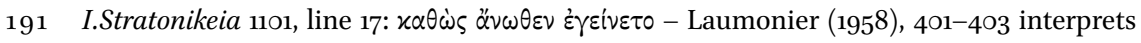
this wider section as involving a second choir of children at the sanctuary (in the peripolion) to sing the traditional hymns, while their urban counterpart sings the new hymns written by the secretary of council; Chaniotis (2003), 186, however, interprets this as renewing "an old tradition which had been neglected" out of piety. In both cases it is unclear how old this tradition would have been, although Chaniotis further points out how hymnody had become popular in the imperial period: "Particularly in the second century, the singing of hymns was regarded as a powerful and effective means of addressing, imploring, and appeasing the gods," Chaniotis (2003), 186. This should further be seen in the context of the 'invention of tradition', Hobsbawm and Ranger (1992).

192 Chaniotis (2003), 186 notes the general moralizing tone of the decree, especially in

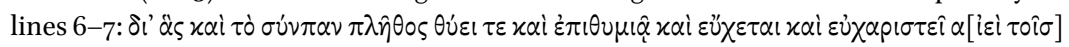

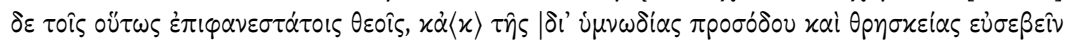

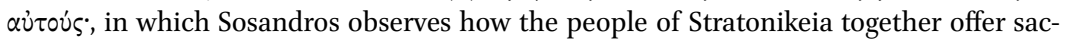
rifices, burn incense, pray, and give thanks, showing their gratitude to the powerful gods, and how they should use hymns in processions to approach the gods (prosodos), showing proper religious worship. 
period. ${ }^{193}$ In the imperial period, a few of the priests at Lagina list among their accomplishments their hiring of professional performers, akroamata, for the festivals. ${ }^{194}$ This was surely within the context of benefactions, the one priest providing even more splendid festivals than the previous, with such special effects.

The acoustic and aesthetic dimensions of the festivals of Hekate underscore how they functioned as grand spectacles in which Stratonikeia shared center stage with the goddess. Mass participation was crucial, not just to witness the ritual events which bound the goddess and the city together, but to enact the relationship by physically being part of it. Besides the processions and the singing of hymns, banqueting and games were two more avenues used by the polis to create social cohesion and thus to solidify its own position in the wider community.

\subsubsection{Banqueting}

At over a hectare in surface area, the sanctuary could obviously accommodate a sizable crowd. Although Lagina did not have the differentiation of banqueting facilities that the Hekatomnids had provided at Labraunda, the large stoa complex did offer a good deal of shelter and was no doubt used for this purpose. ${ }^{195}$

Ritual feasting was an important part of Hekate's festivals, although most of the epigraphic evidence that we have for this derives from the imperial period; by the later second and third centuries AD banqueting had become a main outlet of euergetism, on an increasing scale of expenditure. ${ }^{196}$ These were often

193 IMT SuedlTroas 576 concerns a judge, Amynamenos, son of Bresikleios, from Assos who settled an affair for the Stratonikeians and who consequently is to be honored and crowned by the Stratonikeians during the musical competitions in the celebrations for

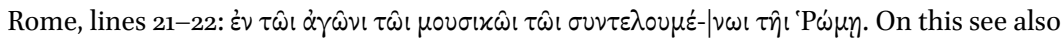
Laumonier (1958), $35^{8}$ and n. 1 ; he contests the editor's date, who places it in the second half of the second century вС, arguing that the festivities for Rome began only after Sulla's letter in $81 \mathrm{BC}$.

194 I.Stratonikeia 530 (lines 9-10) and 668 (line 5), 672 (lines 10-11), and 706 (lines 10-11); all presumably from the second century AD. See also Slater (2004) on the role of akroamata and theatrical performers in general in Stratonikeia.

195 Pottery would surely confirm this activity, and large quantities were found from the Hellenistic period, Boysal (1993). It awaits publication, however.

196 Hekate's banquets were of course part of a wider practice in the city which included the banquets of Zeus Panamaros, but also those of the sanctuaries in town. Laumonier believes that feeding the city in this way was also an act of charity, “... ainsi la majorité pauvre de la population est entretenue littéralement (car les fêtes sont numeraux), par la minorité riche," Laumonier (1958), 397. Although charity was generally not the objective of priestly euergetism (e.g. Veyne (1976), Gordon (1990), Zuiderhoek (2011)), the distributions during the festivals of Lagina and Panamara are explicitly meant for the entire 
paid for by the priests or by another civic official, usually the gymnasiarch; several of the hiereus inscriptions show the priest performing the role of hestiator, and hosting banquets at various locations, and for various groups, i.e. sometimes all of the population or a part, often at the sanctuary but also in town. ${ }^{197}$

The banquets often took place at the sanctuary (peripolion); one late inscription from the third century AD shows how a priest sponsored a buffet table for the goddess, probably during the sacrificial banquet. ${ }^{198}$ Banquets, however, were also often held in town, as were the festivities of the Panamareia, the great urban festival for Zeus Panamaros. ${ }^{199}$ Lagina was in fact one of the venues for ritual feasting during the Panamareia, showing how tightly interwoven the cults of both deities had become with the polis, at least during the imperial period. ${ }^{200}$

This incorporation of the wider landscape of the polis, both local and urban, in ritual dining was a way to tie the various surrounding communities together. The very fact that everyone joins in the same banquet at the same time, even though they may celebrate it in different localities, creates an awareness of community and a sense of unity. ${ }^{201}$ The operative dynamic at work here is virtually the opposite of that at the sanctuary of Sinuri, which clearly served as a geographical magnet for the (dispersed) community of the Pormounos, drawing them in from wherever they lived. Hekate's festival, by contrast, brought the ritual focus out to the people through the banquet, wherever it took place. As it integrated the public and communal places throughout the wider community,

population, rather than the happy few, though clearly creating a system of dependencies; further discussed in Chapter 6.

197 Laumonier (1958), 395 n. 4. Often times these were combined with the position of gymnasiarch during the festival, e.g. I.Stratonikeia 684, from the later second century AD. On a few occasions meals were specifically provided for foreigners, e.g. the Nyseans, I.Stratonikeia 664 and 697 .

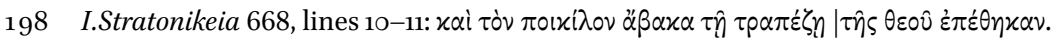

199 Laumonier observes that while priests continued to give out money during the festivals, e.g. I.Stratonikeia 701 , lines $6-8$, that increasing expenditures were made on public banquets, either for the whole population or a part of it, e.g. in I.Stratonikeia 668; Laumonier (1958), 396. On the Panamareia, see below, Chapter 6.

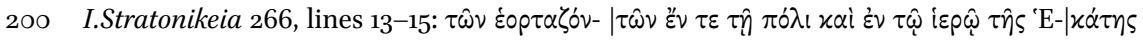

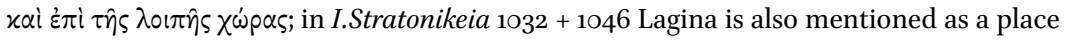
where oil was distributed, perhaps during the festival of the Panamareia as well, see below.

201 A parallel may be drawn with modern religious holidays that center on ritual dining, such as the village panegyri in modern Greece or Şeker Bayramı in Turkey, or even Thanksgiving in America; although the importance of the home as locale in these celebrations is paramount, they are nonetheless religious festivals which use food to help build the idea of community and even national and cultural identity. 
it worked very much like the centripetal procession of the key, moving from the sanctuary at the periphery of urban space into the heart of the town. These rituals helped to establish the pattern of intimacy between goddess and community, which lay at the base of the identity of the polis.

\subsubsection{Games}

Ritual competition was another avenue for building solidarity, by emphasizing group identity and mutual recognition, especially among the many poleis who participated in them and competed against each other. The games were clearly part of the reorganization of the festivals in the Hekatesia-Romaia as they were stipulated in the first decree that also called for a list to be inscribed of the cities and rulers that recognized the asylia of the sanctuary and who participated in the games. ${ }^{202}$

Most of the evidence regarding the types of games and competition stems from the imperial period, but it would seem that the focus was primarily on athletic contests. One such inscription refers to both wrestling and the pankration, a kind of mix between boxing and wrestling with a considerable degree of violence. ${ }^{203}$ Another inscription from Kos, from the later first century вС, is even more revealing of the events but especially the wider context of the games. This inscription lists the accomplishments of a successful young athlete, presumably from Kos, who was twice victorious in the 'Hekatesia in Stratonikeia', winning the pentathlon first in the 'Isthmian boys' category and later in the age category 'beardless pentathlon'.204 But he participated in several other festivals as well, earning victories at Metropolis (in the Kaisareia), Nysa (in the Theogamia), Kolophon (in the Klaria), Halikarnassos (in the Archegesia, three times), Myndos (in the Apollonieia), and in the Eleusinia and Kaisareia festivals, which were presumably on Kos itself as the locations of these festivals is not mentioned. Interestingly, Kos is not on the list of those who initially recognized the asylia of Hekate or participated in the Hekatesia-Romaia (see

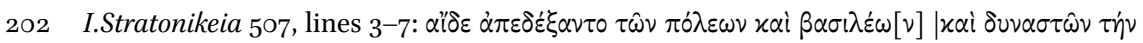

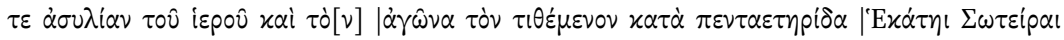

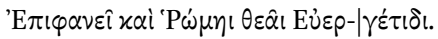

203 In I.Stratonikeia 547, from the imperial period, a certain Eubolos, son of Iason is praised

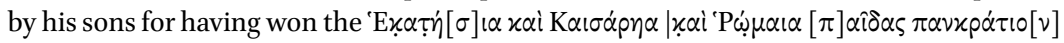

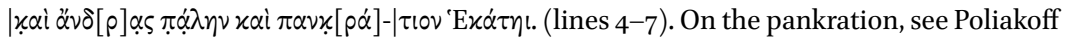
(1982), 10-11.

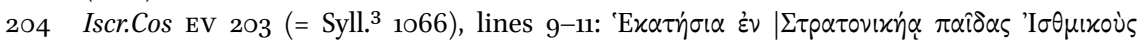

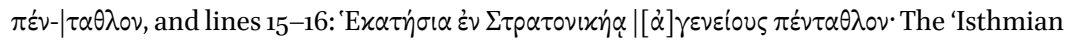
boys' and the 'beardless' pentathlons are also known from Iscr.Cos EV 218, another list of athletic victories from Kos from the first century BC. 
Figure 5.25 below), ${ }^{205}$ but this inscription shows that this list was only a starting point for the expansion of Stratonikeia's network, especially within the region of Karia and its immediate surroundings.

From this inscription we gain a very real mental map of the wider network of festivals and athletic circuits in Karia and the Aegean, of which the Hekatesia was now part. Laumonier observes that Stratonikeia in this way was putting itself on a par with a few of its extended 'neighbors and rivals' in Karia, especially Kos, Magnesia on the Maeander, and Miletos, who had panhellenic and penteteric festivals of their own. ${ }^{206}$ On a higher level, it seems that this was an excellent way for the relatively young polis, which had just suffered severe damage in the Mithridatic wars but now enjoyed the full support of Rome, expressed exactly through this cult, to put itself on the global map as an important city. ${ }^{207}$ In fact, although Lagina was the place which Strabo cites as a Karian milestone, ${ }^{208}$ it was Stratonikeia which the young Koan athlete above remembered in connection with the Hekatesia. It is of course not unlikely that some of the events actually took place in town, as with the procession of the kleidos agoge and the banquets; the point, however, is that the festival of the goddess in Lagina was now inextricably linked with the polis in the memories of the participants and the minds throughout the wider Greek world.

To summarize, little is known of Hekate's rituals prior to the involvement of Stratonikeia, but the later urban festival of the kleidos pompe, with the spectacle of the procession of the goddess' sacred key as it was brought from the sanctuary into town, surely created a strong centripetal force that drew the different local communities into the citizen body. At the same time, it reinforced the new social hierarchy as the most prominent families were literally at the head, with the kleidophoros, the young girl or maiden who led the procession, as star and who kept the prestigious title as she matured. Probably ending at an altar in the heart of town, the processions culminated in sacrifices with a

\footnotetext{
205 I.Stratonikeia 508.

206 Laumonier (1958), 359: "Stratonicée, tard venue dans la communauté hellènique, cherche à se mettre au niveau de ses voisines et rivals, Kos, Magnésie, Milet." On the increasing association of deities on civic coinage in association with games, see Meadows (2018).

207 See van Nijf (2006) and (2010) on the increasing role of athletics in shaping urban identity, also van Nijf and Williamson (2016) on the geopolitics of festivals and van Nijf and van Dijk (2020) for engagement with Rome. This the focus of the research project Connecting the Greeks. Multi-scalar festival networks in the Hellenistic world, at the University of Groningen (2019-2023), sponsored by the Netherlands Organisation for Scientific Research (NWO) and jointly directed by O.M. van Nijf and the author.

208 Strabo 14.2.29, cited above, mentions the distance from Physkos to Lagina, and then from Lagina to Alabanda.
} 
large ritual feast for the population afterwards. ${ }^{209}$ Hekate's banquets were not affixed to the shrine but incorporated the civic landscape and were another important coordinating mechanism that fostered both internal social cohesion and external political networks. While the kleidos pompe principally concerned the internal cohesion of Stratonikeia, the Hekatesia-Romaia had wider geo-political overtones as it put Stratonikeia on the map as an important Greek city, prominent before Rome. The asylia granted by Sulla after the Mithridatic wars was answered with the cultic unification of Stratonikeia's prime goddess with Thea Romē and was celebrated as a panhellenic festival, with contests. In the end, this is exactly what these festivals were about, mass participation around a common focus. This was aimed at the composite community of Stratonikeia through the processions, banquets, and distribution of goods, but also simultaneously at the wider world through games and competitions. The spectacles of Hekate provided both a show and a participatory event that increased the sensory involvement of the observers, capturing the attention of the community at large. ${ }^{210}$ The Stratonikeian festivals of Hekate were in every sense rational rituals. ${ }^{211}$

\subsection{Legal Administration and Organization of Lagina}

The physical and festive expansion of the sanctuary and cult at Lagina was the most prominent part of the reorganization of the cult, streamlined as it was to meet the needs of Stratonikeia. Yet an examination of the administration of the sanctuary, through the priesthood and local community at the sanctuary, brings us closer to the real agents of change. Most of the evidence for the administration of Lagina appears after the reorganization of the festivals, especially the Hekatesia. ${ }^{212}$ The priesthood in particular shows how tightly integrated the sanctuary was with the polis, legally, administratively, and economically. This office was a high-profile position, but there was also a local community at the sanctuary that was intertwined with the polis, and which appears to have had a vital role in the economic dealings at Lagina itself.

209 For the suggestion of the altar as final point, Laumonier (1958), 385 and 398: "En ville s'élevait sans doute un grand autel de la déesse, peut-être au Bouleutèrion ..." Such an altar has not yet been located.

210 On the mnemonic effects of sensory events, e.g. the 'flashbulb memories', and their impact on the recall of ritual, see e.g. McCauley and Lawson (2002), Chapter 2, 38-88 and McCauley and Lawson (2007) 236-238; discussed above in Chapter 2.

211 Chwe (2001), also Rappoport (1979), discussed above in Chapter 2.

212 The priesthoods of Hekate at Lagina and Zeus at Panamara are discussed in more detail in Williamson (2013b); see also Ackermann (2013). 


\subsubsection{Administration and Priesthoods}

Menophilos, son of Leon, is the earliest known priest of Hekate and is mentioned in an inscription in which he is charged by the council, presumably of Stratonikeia, with the priesthoods of Helios and Rhodes as well. ${ }^{213}$ This inscription is dated to the early second century BC when Stratonikeia was part of the Rhodian peraia, and is a premonition of the way in which Hekate's cult was later used to advertise the alliance of the polis with Rome. It shows the significance of the sanctuary already in the early second century, while it was presumably still an open-air shrine. Once the temple was erected, it acquired a secondary function as archive as several documents pertaining to the shrine and its administration were inscribed on its walls. ${ }^{214}$ Besides the Senatus consultum and the ensuing list of cities that recognized the asylia, several lists of priests were also inscribed here from the Hellenistic period. ${ }^{215}$ These appeared after the Senatus consultum was inscribed and show among others that the priesthood of Hekate was annual, as well as who was priest during the great festival, the penteteria. The priesthood was clearly a civic institution by this time. The nature of the priesthood is largely known from the many hiereus inscriptions in which the priests listed their accomplishments and deeds of benefaction performed while in office. ${ }^{216}$ Nearly all of these appear to belong to the imperial period. Together, the hiereus acts and honorific decrees make up by far the largest category of published inscriptions from Lagina (Table 5.1). Most were inscribed on the walls of the temple, wherever space allowed, apparently in no particular order. ${ }^{217}$

Thanks to the naming convention common to Stratonikeia, i.e. namepatronymic-demotic (usually abbreviated), ${ }^{218}$ one can see that priests came from all across the territory of Stratonikeia, since Koranza, Koraia, Koliorga, Lobolda, and Hiera Kome all appear among the demotics of their names. ${ }^{219}$

213 I.Stratonikeia 504. Helios was the main god of Rhodes. The naiskos dedicated by Hermias Athanagoras may have been related to this cult if the dates are correct and he was in fact a Rhodian, I.Stratonikeia 1424.

214 On this phenomenon, see Roels (2018a).

215 I.Stratonikeia 601-622, with fragmented lists in 729, 740-741. Only two of these, I.Stratonikeia 613 and 615 , are known to date from the imperial period.

216 I.Stratonikeia $623^{-739,} 1438$. These 115 inscriptions make up nearly half of the 233 inscriptions found at Lagina.

217 Inscriptions from different periods thus appear almost criss-cross between each other, as observed by Laumonier (1958), 372; see also van Bremen (2010).

218 Discussed above at the beginning of this chapter in connection with the use of the demotic in determining the geographical composition of Stratonikeia.

219 Koranza seems to appear the most often, but too many demotics are unknown or not given (probably in the second or early first century вс, before this was as commonplace) to warrant a statistical quantification or comparison. 
TABLE 5.1 Breakdown of inscriptions at Lagina according to type and period

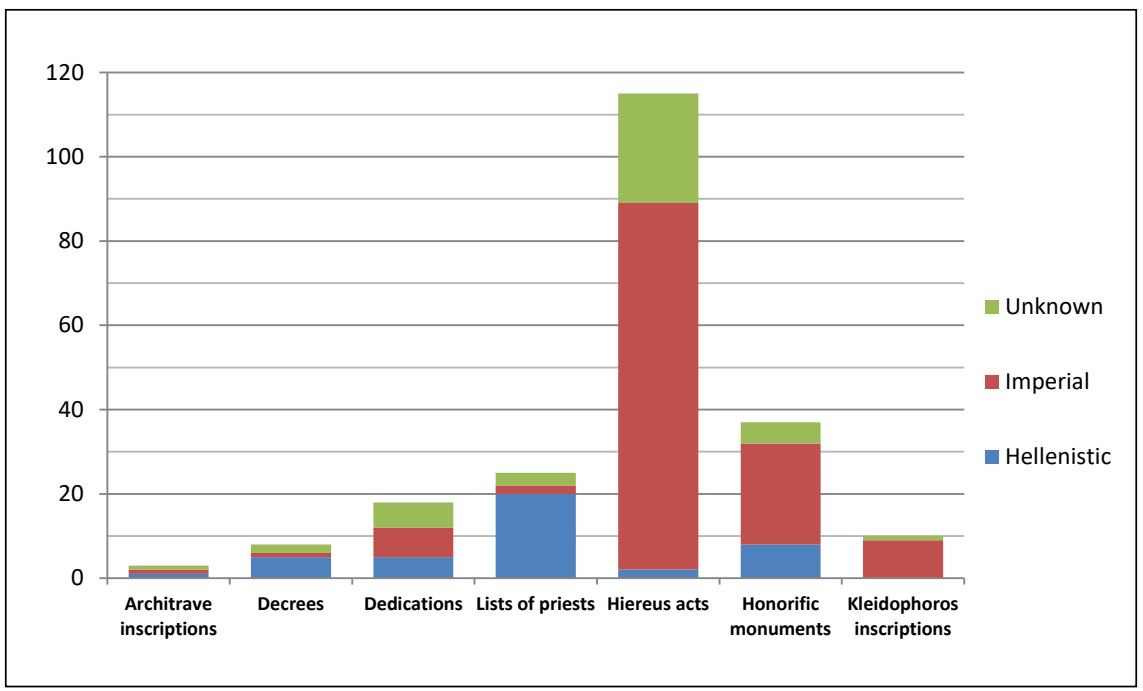

Excluded are the Senatus consultum from 81 вс (I.Stratonikeia 505 ), the list of responding cities (I.Stratonikeia 507), and a single funerary inscription of unknown date (I.Stratonikeia 551)

Also, this convention allows for the identification of many of the individuals and their relations with a considerable degree of precision. Alfred Laumonier was able to use this information to study in detail the priesthood of Hekate at Lagina, drawing a sequence for a general chronology. ${ }^{220} \mathrm{He}$ was thus able to discern 265 individual names, 200 of which were priests prior to the time of Trajan, and 75 before Augustus. Of all of these individuals, 120 names are known only from the lists, while 86 priests provided a summary of their accomplishments. ${ }^{221}$ These 86 priests cover a period of roughly the first two centuries AD.

Strictly speaking the period of these later inscriptions falls outside the scope of this present research, yet they are nonetheless included here to show how the priesthood of Hekate became one of the most high-profile public positions in Stratonikeia. The priesthood was a centralized institution and priests were drawn from the elite of the polis. Laumonier observed a shift in the information level of the documents: whereas the earliest in the Hellenistic period seem

220 Laumonier (1938b), and again in Laumonier (1958), 372-391; he performed a similar study on Panamara, Laumonier (1937) and (1938b). His work on this topic is based in part on the initial findings of Cousin and Diehl (1887), Deschamps and Cousin (1888a-c), and Hatzfeld (1920).

221 Summed up in Laumonier (1958), 372. 
to just record the end of the office of priesthood, ${ }^{222}$ over time they begin to describe with increasing detail the benefactions made by the priest, including giving money to the population, distributing oil among the population, hosting banquets, paying professional performers, but also constructing parts of the sanctuary. ${ }^{223}$ This probably reflects a shift in the expectations of the office towards a more philanthropic or crowd-pleasing role, and Laumonier sees this as the prime reason that the priesthood occurred in smaller circles, especially in the later imperial period.224 Priests were also significantly involved in financing the architecture and its maintenance. The southwest stoa, with the theatron, appears to have been dedicated in the early first century AD by the priest Aristeas, son of Aetion, while Kleinomachos, son of Drakon, gave 6000 drachmas for another wing of the stoa complex, both priests were from Koranza; in the third century AD a stoa was decorated by Epainetos, of Koliorga, and his wife Flavia. ${ }^{225}$ Lavish attention was paid on the shrine by the priestly couple M. Ulpius Alexandros Herakleitos and his wife Ulpia Ammion, both of Koliorga, who appear to have dedicated among others a propylon and stoa for the live market. ${ }^{226}$

The financial burdens that came with the office could be shouldered only by the wealthiest families of Stratonikeia, and these were few in number; recruiting priests was therefore not an easy task, and it is unclear whether this was an elective or voluntary position. ${ }^{227}$ The priesthood of Hekate was often occupied by various generations of the same family, and repeatedly by the same

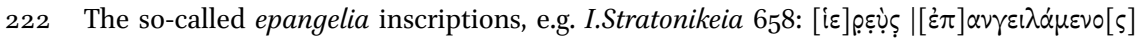

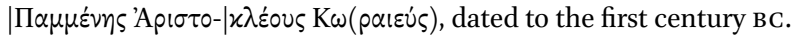

223 Laumonier (1958), 366 and 372; the banquets and performers, i.e. akroamata, are discussed above in the previous section on ritual performance.

224 Laumonier (1958), 366-368.

225 I.Stratonikeia 653 and 651 for the dedications of Aristeas and Kleinomachos, respectively; the dedications of Epainetos (of Koliorga) and his wife Flavia are mentioned in I.Stratonikeia 684 and 685. Phanias, son of (a different) Aristeas, dedicated bronze doors, I.Stratonikeia $65^{8}$, lines $5^{-10}$, second century AD. Meier (2012), 145-151, on construction activities of priests.

226 I.Stratonikeia 530 and 668 , second century AD; especially interesting is the mention of the three stoas.

227 Laumonier (1958), 368. A parallel situation may be found for council members in Egypt, where some of the elite were literally forced to assume the position while others could simply not afford it, see Tacoma (2011). This financial burden may also explain some Mylasa's problems in recruiting priests, as Dignas noticed, Dignas (2002a), 209-210; here she further observes that at Athena sanctuary in Herakleia under Latmos, "... the goddess herself appears as priestess several times during the first half of the first century AD." 
individuals on separate occasions. ${ }^{228}$ Moreover, several individuals occupied both the priesthoods of Hekate at Lagina and Zeus at Panamara, some 18 kilometers away from Lagina to the south. One notable figure, Marcus Sempronius Clemens, even held both offices simultaneously. ${ }^{229}$ By the third century AD, the appointment of the priesthood was sometimes announced as reflecting the divine will of Hekate - for those who could afford it. ${ }^{230}$

By tracing the careers of different priests, Laumonier was able to show that at least by the imperial period the priesthood of Hekate had become one of the highest civic offices in Stratonikeia: "La prêtrise d'Hékate était la plus importante dans la série des grandes prêtrises stratonicéenses; elle couronnait généralement la carrière; on exerçait d'abord à Panamara, puis à Lagina; le cas inverse se présente, mais beaucoup moins souvent, et surtout chez des prêtres qui renouvellent à Panamara." 231 The course of the priesthoods also shows how the two principal cults of Stratonikeia, that of Hekate and that of Zeus Panamaros, became more and more intertwined; Lagina, in fact, was one of the venues for distributing oil to the population during the Panamareia. ${ }^{232}$ Giving out oil and money was a regular feature of the cult at Panamara and seems to have been introduced at Lagina. Also, at Lagina it became custom to have a priestess next to the priest, as at Panamara, although Laumonier believes her role here was much more subordinate. ${ }^{233}$

228 I.Stratonikeia 310 is the priestly inscription of Marcus Sempronius Auruncius Theodotos, son of Arrianos, who set up a statue of his grandfather or great-grandfather ( $\dot{\varepsilon} \pi i \pi \alpha \pi \pi \circ \varsigma)$ (Marcus) Sempronius Claudius, who was one of the most active priests of Zeus and Hekate in the later second century AD, see below. Theodoros, son of Theophilos, was priest of Hekate five different times, with the fifth one falling in the penteteria, I.Stratonikeia 669 (broadly dated to the second century AD), see further Laumonier (1958), 367 and n. 2.

229 I.Stratonikeia 289 (second half of the second century AD) gives the epangelia of Marcus Sempronius Claudius at Panamara in the Heraia, while being priest of Hekate. He had been priest at Panamara on five separate occasions, Laumonier (1958), 367; also Nilsson (1927), 40o. On the career of Marcus Sempronius Claudius in general, see Deschamps and Cousin (1888a); Laumonier (1958), 277-28o, 367; Williamson (2013b).

230 E.g. the appointment of Tiberius Flavius Aeneas from Hierokome in I.Stratonikeia 704,

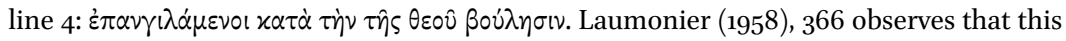
phrase is more frequently used at Panamara, where Aeneas was twice priest; his wife Ulpia Leaena, who joined him as priestess at Lagina, had also been the priestess of Artemis at Koranza, see Laumonier (1958), 385 .

231 Laumonier (1958), 367. Priesthoods at Didyma and Klaros were also occupied by members of the urban elite in the Roman period, see Busine (2013).

232 I.Stratonikeia $1032+1046$, discussed below. The Panamareia formed the longest festival of Zeus at Panamaros and is discussed in more detail in Chapter 6.

233 Laumonier (1958), 368. The role of priestess at Lagina was typically fulfilled by a female related to the priest, either as wife, mother or daughter. Unlike Panamara, where the priestess was clearly responsible for the cult of Hera, the duties at Lagina were not specified 
Young women played a highly visible role in the cult of Hekate at Lagina as the kleidophoros, the girl or maiden who carried the key from Lagina to Stratonikeia during the kleidos pompe, sometimes accompanied by her brother, the parapompos or kosmophoros. ${ }^{234}$ The kleidophoros received separate mention on the walls of the temple, and she was also the one who presided over the distributions of oil and money among the population, usually at the side of her father, the priest. ${ }^{235}$

The image of the priesthood that arises out of this is a high profile public position in which the focus was both on the priests and their families. Occupied by different members of the elite of Stratonikeia, priests no doubt served as role models, which would have been a way to promote general family values while at the same time distinguishing themselves and sustaining a social imbalance through their expenditures, gifts, and monetary distributions.

The administration of the cult was ultimately the responsibility of the priests, although other cult personnel must have been involved in maintaining such a major sanctuary. Besides the priesthood, little is actually known of how the sanctuary was run in the Hellenistic period, although an inscription on one of the antae of the temple, dated to the first century вс, mentions some kind of return after a crisis to the administration of the sanctuary as it had been before according to the traditions and earlier decrees. ${ }^{236}$ Apparently regulations or prescriptions on the organization of the sanctuary were inscribed that are no longer preserved. In the third century AD, mention is made of a neokoros, responsible for the general management of the sanctuary and in this case for overseeing the care of the sacred grove, which was to be maintained by the eunuchs, who were subordinate to the priest. ${ }^{237} \mathrm{~A}$ eunuch was also honored in

and the position seems to have been optional, perhaps even more of an accessory to the priest. The name of the priestess in some cases only appears at the end of the inscription (which is ironically often better preserved than the top part). Van Bremen (1996), 114-115, on the increasing occurrence from the first century BC on of married couples occupying a priesthood together.

234 Laumonier (1958), 368. The parapompos or kosmophoros are mentioned in I.Stratonikeia 683 and 690 , discussed above.

235 Laumonier notes how the names of the kleidophoroi usually appear before those of the priestess in the hiereus inscriptions, and were also mentioned on their own on a number of occasions, Laumonier (1958), 368.

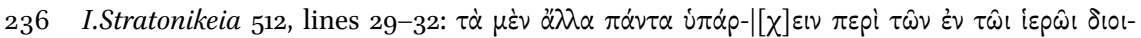

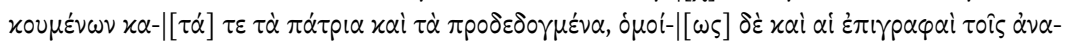
$\theta \dot{\eta} \mu \alpha \sigma \nu \dot{\varepsilon} \pi \imath[-]$. On the location, Tirpan et al. (2012), 195, also n. 57. The date is based on the turbulence of this era, but see van Bremen (2010), 499-502, for an earlier date to the second century вс.

237 I.Stratonikeia 513, line 40 mentions the role of the neokoros, while line 34 shows that the eunuchs were responsible for tending to the grove, discussed below. 
another fragment from the mid-third century. ${ }^{238}$ Much has been made of this appearance of eunuchs and has led to Burkert's one-line summary of Lagina as '... ein Tempelstaat orientalischen Typus, wo es auch 'heilige Eunuchen' gibt," which is entirely misleading. ${ }^{239}$ Their role prior to the third century is unknown, but could hardly have counterbalanced the strong urban nature of Lagina. Burkert's classification seems more concerned with the ethnically biased categorization of sanctuaries in Asia Minor, as developed by Ramsay in the nineteenth century and dismissed by Debord. ${ }^{240}$ All in all the priesthood of Hekate shows that her cult at Lagina was in every sense a polis cult for Stratonikeia.

\subsubsection{Local Community - The 'Katoikountes in the Peripolion'}

Although Lagina may not be the location of Hiera Kome, as Robert had presumed, ${ }^{241}$ the sanctuary nonetheless hosted a community in its own right. Şahin views Lagina as one of the ancient demes of Koranza, although the community at the sanctuary appears to be from a later period. Rather than being known as a deme or a koinon (the term syngeneia is not typically used in Stratonikeia as it is in Mylasa), they are simply referred to as the 'dwellers', or 'settlers' (katoikountes) of the sanctuary. ${ }^{242}$ The sanctuary is generally called the hieron, or more typically the peripolion. ${ }^{243}$

The inscriptions mentioning the katoikountes all date from the second or third century AD, and at present it is difficult to say with any precision how old this settlement may have been; as mentioned at the beginning of this case

238 I.Stratonikeia 544 is a fragment of an honorific inscription for a eunuch of the goddess, showing that this person was highly revered.

239 Burkert (1977), 266; Gimbutas (1982), 197, took this fantasy much farther, assuming that since there were eunuchs there must also have been orgiastic dances at Lagina; see also Johnston (1999), 206. Laumonier (1958), 370 points out the oriental character of eunuchs in general, and how they appear in Karia at least until the seventh century AD, even in Christian circles (p. 370 n. 3), but at Lagina their position seems to have been very low key, as at Ephesos with the cult of Kybele (p. 370 and n. 4, referring to Picard (1922), 135).

240 Ramsay (1890) and Debord (1982), discussed in Chapter 2.

241 Robert (1937), 558, opposed by Şahin (1976), 1-15 and more recently in I.Stratonikeia III, p. 1-8, which argues for the site of Stratonikeia to be Hiera Kome, probably related to the sanctuary of Zeus Chrysaoreus.

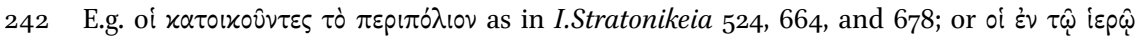

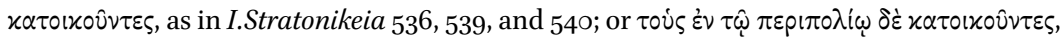
as in I.Stratonikeia 682; no. 672 contrasts those living in the city ( $\tau \dot{\eta} \nu \pi \dot{\lambda} \lambda(v)$ with those liv-

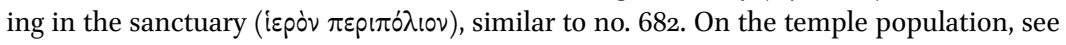
also Caldesi Valeri (1999), 226-23o.

243 The peripolion generally indicates the architectural enclosure; see above under Architecture, with references. 
study, excavations at Lagina are ongoing and have yet to be published. Some of the ceramic material awaiting publication may well be related to settlement activity, including the loomweights and unguentaria. ${ }^{244}$ Nonetheless, it is interesting to note that the consistent designation of 'en toi hieroi katoikountes', or 'en toi peripolio de katoikountes', literally refers to those within the confines of the stoa enclosure, rather than just outside the temenos area, as at Labraunda, ${ }^{245}$ or in a sacred village, as at the sanctuary of Sinuri. This community therefore probably dates from at least some time after the construction of the temple complex. Behind the rather bland designation of katoikountes was a strong local community that on at least four occasions joined the boule and demos in honoring individuals at the sanctuary, including two priests, a kleidophoros, and an agoranomos. ${ }^{246}$ The official and political nature of the honoring bodies in these decrees led Caldesi Valeri to interpret the katoikountes as the remnants of an old religious group associated with the cult. ${ }^{247}$ By the second or third century AD the organization may well have been a century or two old already. Nonetheless, the lack of a more formal designation seems odd, and may indicate that this was a changing group of people, such as cult personnel, travelers, those seeking asylum or other temporary residents.

The katoikountes probably would have included the eunuchs mentioned above, who were responsible for caring for the sacred grove (hieron alsos). ${ }^{248}$ This seems to have been somewhere within the temenos, and it is tempting to project it onto the vacant space on the plan between the propylon and

244 Also discussed above, under Festivals. For loomweights, Tirpan and Söğüt (2007a) and Tırpan and Söğüt (2008). For unguentaria: Tırpan (1997); Trrpan and Söğüt (2007a); Tirpan and Söğüt (2000).

245 Or the sanctuary of Meter Theon at Mamurt Kale, where extensive remains of probably a settlement may be found south and west of the temple complex; Conze and Schazmann (1911), 12 and personal observation.

246 I.Stratonikeia 536 honors the priestess Ammion Apphion with a statue, and I.Stratonikeia 539 honors a priestly couple and their family. I.Stratonikeia 540 honors a kleidophoros; I.Stratonikeia 524 honors an agoranomos, see below.

247 Caldesi Valeri (1999), 226-23o. The (sacred) gerousia (society of older men, usually affiliated with the gymnasium) joined the boule and demos, and the katoikountes in bestowing honors for priests on at least two occasions, e.g. I.Stratonikeia 536 and 539 .

248 I.Stratonikeia 513 concerns the protection of the grove, and the eunuchs who tend to

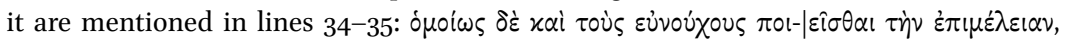
from the third century AD. Sacred woods were common, see Cazanove and Scheid (1993), and Bonnechere (2007). In this study, Labraunda possessed a sacred grove of plane trees (Hdt. 5.119) and at the sanctuary of Sinuri it was the subject of a legal trial (I.Sinuri 2 and 11, discussed in Chapter 5). 
southeast stoa (Figure 5.8). ${ }^{249}$ Laumonier suggests that the wood was a cultivated grove of trees, which could in fact have been anywhere in the sanctuary. ${ }^{250}$ The inscription that primarily concerns the protection of the sacred wood mentions the neokoros and the councillors from the katoikountes who are to be responsible for this duty. ${ }^{251}$

The sanctuary of Hekate at Lagina was clearly a lively place; even the numbers of monuments and statues indicate that it was much fuller than the plan on Figure 5.8 indicates. One of the hiereus inscriptions, albeit from the third century AD, mentions the construction of 'the three stoas for the sacred house, and the propylon with the entrance and the stoa in front of the oikia (house) that (leads to) the biotike agora (food market).'. ${ }^{252}$ This may refer to the southwest wing with the 11 steps - the context is interesting in connection with the 'food market' (biotike agora) that was just next to this.

\subsubsection{Economic Resources}

The biotike agora, live or food market, may well have been the working space of Hermias Chrysaoros of Koraia, the agoranomos who was honored by the katoikountes, together with the polis, for lowering the prices at his own expense during his term. ${ }^{253}$ It is unclear exactly which agora is meant, although the fact that Hermias worked under the priest may imply the market at Lagina. Another agoranomos, Hekaton, son of Hierogenus, of Koranza, dedicated a marble altar to Hekate at Lagina. ${ }^{254}$

249 One inscription prohibits animal herds in the grove: I.Stratonikeia 513 , lines $36-37$ : $\dot{\varepsilon} \alpha \nu$

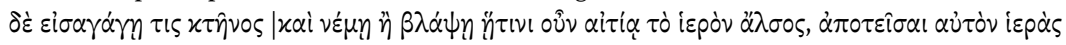
'Exátns. Herds may have been in the area for general grazing, or in preparation for sacrifices, or perhaps in connection with the food market (biotike agora) discussed in the next section.

25 Laumonier (1958), 364 .

251 I.Stratonikeia 513 , line 40.

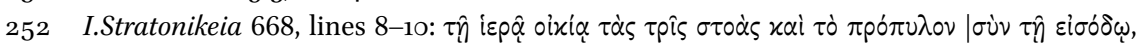

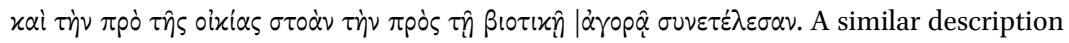
is given in I.Stratonikeia 530, lines 11-13, an honorific decree by the demos, boule and the gerousia for the same priest, Marcus Ulpius, and the same deeds which he listed in his hiereus inscription.

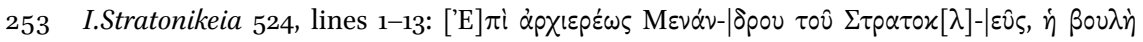

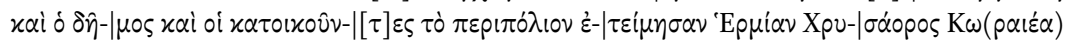

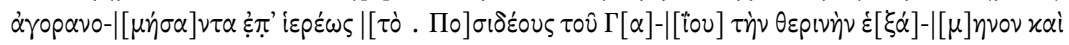

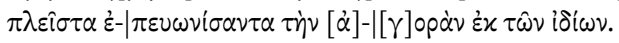

254 I.Stratonikeia 1421 (= EA 34 (2OO2), 6-7, no. 8), dated to the 'Roman period'. The altar was found near the propylon but was probably not in situ. Yet another another agoranomos, Eros, son of Menander, of Koraia, dedicated a statue of Hermes to Hekate Soteira and the demos at Lagina, I.Stratonikeia 516, the inclusion of Hekate's epiklesis Soteira indicates 
In any event, the biotike agora is described as a fixture at the sanctuary in the third century $\mathrm{AD}$, and it is tempting to consider it in connection with the convenient location of Hekate's sanctuary at the crossroads of the Marsyas valley and the Hayırlidere valley, conducive to trade. Perhaps the sanctuary acted as a kind of emporion or 'suburban' market, with easy access from different directions. $^{255}$ This was probably the case at least in the later Roman period. The herds of livestock referenced in connection with the hieron alsos, and perhaps the sacred grove itself if, as Laumonier presumes, it contained cultivated fruit trees, ${ }^{256}$ may have been connected with the produce available at the live market. The financial base of the sanctuary is otherwise unknown, but the decree posted after the Senatus consultum of 81 BC, which mandates the ensuing inscription of the list of cities that acknowledge the asylia, states that the treasurers, or tamiai, are to provide for the inscription of this list using Hekate's funds. ${ }^{257}$ This demonstrates an institutionalized approach to the sanctuary and its holdings, wherever the money actually may have come from.

In the context of the festivals of Zeus Panamaros, oil was distributed to the population at various places in the city but also at Lagina, indicating some kind of role in the economy of the district, at least for the local area. ${ }^{258}$ During the Genethlia, the festival connected with the birthday of the goddess, gifts of money and oil were also distributed by the priests among the population, very similar to the practices at Panamara during the festivals for Zeus and Hera. ${ }^{259}$ The third-century AD hiereus inscription mentioning the food market (biotike agora) also shows that gifts of oil and money were distributed to the needy

a date in at least the first century вс or later. A statue of Hermes was also dedicated to Zeus and Hera at Panamara by the priest, Menander, son of Apollodotos (no demotic preserved) and the demos in I.Stratonikeia 412, dated to the second or first century BC.

255 On festivals as venues for markets and fairs of regional and sometimes of inter-regional importance: de Ligt (1993); Chandezon (2000); Iannaccone et al. (2011); Papazarkadas (2011); García Morillo (2013); Frejman (2020).

256 I.Stratonikeia 513. Laumonier (1958), 364 suggests that the stipulated maintenance of the grove by the eunuchs suggests cultivated fruit trees.

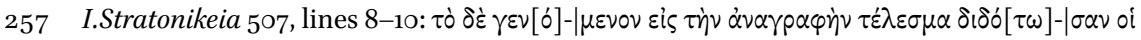

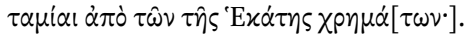

258 E.g. I.Stratonikeia 1032 with 1046.

259 Laumonier (1958), 393-397; the gifts of money, but also oil, were also typical of the cult of Zeus Panamaros, see below in Chapter 6. Typically given from the personal resources of the priest to the population, this was an ostentatious act of a personal euergetism; Dignas (2002a), 210-211, interprets such behavior as an indication of real political power, going beyond urban euergetism. Distributing oil to the entire population was a common phenomenon in imperial Asia Minor, see Zuiderhoek (2009), 89-92, who links the distributions to a general city-wide participation in the identity of the gymnasium culture. 
in the sanctuary year-round. ${ }^{260}$ One instance mentions the priest Hierokles (from Hierokome) and his wife Ada (from Panamara), who provided the grain fund (sitonia). ${ }^{261}$ These distributions indicate that the cult of Hekate, its sanctuary, and particularly its priests played a central role in the local economy, at least by the imperial period, also in sustaining a system of dependencies.

Sacred lands were a vital source of income at the sanctuaries in the chora of Mylasa, yet they are only vaguely alluded to at Lagina. ${ }^{262}$ One inscription from $39 \mathrm{BC}$ is an expression of gratitude to Hekate by the demos for restoring her sacred lands in Alossos and the phylai of Korollos, no doubt after the attacks in the area by Labienus. ${ }^{263}$ This is the closest indication we have of the economic base of Lagina in the Hellenistic period. What the financial situation was further like at the sanctuary, how the sacrifices were paid, or what role it occupied in the local economy remains to be discovered; hopefully the ongoing investigations will shed more light in this area.

In summary, the walls of the temple became a ledger for sacred archives, and one of the most prominent inscriptions was the Senatus consultum of 81 BC. This was apparently a turning point in the organization of the cult and the many lists of priests, corresponding with the years of the quadrennial festival, date from after this time. The organization of the major international festivals of Hekate and Thea Romē would have been a tremendous task and this was no doubt a highly distinguished office held by the elite of Stratonikeia, as it was later in the imperial period, when it became one of the important urban posts for euergetic display, along with the priesthood at Panamara. ${ }^{264}$ The lists of names further show that the priesthood was an annual position, and the diversity of demotics and patronyms prove that it was not restricted to any one family. By the imperial period there was also a more or less permanent population in the peripolion at the shrine called the katoikountes that appeared next to the boule and demos (and sometimes the gerousia) in honoring individuals. The eunuchs

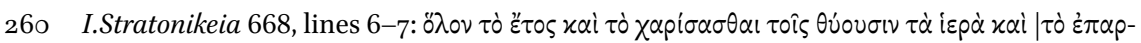

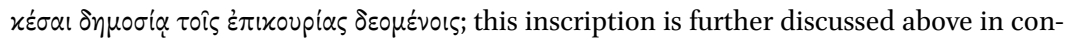
nection with the biotike agora.

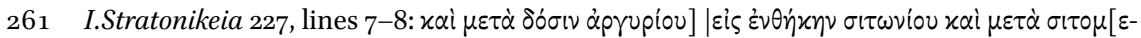
$\tau$ qi $\alpha v$. The inscription was found at Panamara, but only mentions their term as priests of the Great Goddess Hekate.

262 E.g. in I.Stratonikeia 512, lines 21-22 mention 'those who commit sacrilege in our country

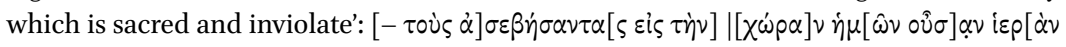

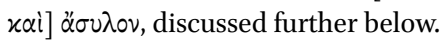

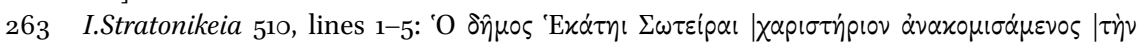

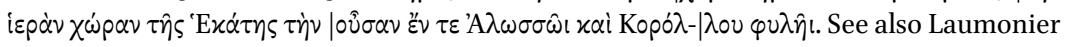
(1958), 365 and Deschamps and Cousin (1887), 238.

264 See below in Chapter 6; also Williamson $(2013 \mathrm{~b})$. 
mentioned in later inscriptions may have been part of this; one of their roles was to cultivate the sacred wood in the sanctuary - perhaps a grove or orchard that yielded produce for the market or local consumption. Regarding the economy, an important feature at Lagina known from later inscriptions is the market, or biotike agora, demonstrating the importance of the shrine in the economy of the wider region. The financial base of the sanctuary during the Hellenistic period, however, is unclear. Sacred lands are not as prominent as those in the territory of Mylasa. Evidence of any major shifts in administration is thus lacking, yet the new scale of festivals must have required additional sources of income. In later periods, both the sanctuary and the priests clearly played a central role in the economic life of the polis, through their benefactions, i.e. gifts of oil and money to the population, and the inclusive banqueting; this mirrors the cult practices at Panamara, as will be shown further below in the next case study.

\subsection{Urban Mediatization at Lagina}

Until now we have examined the impact of Stratonikeia on the sanctuary of Hekate at Lagina, with its festivals and administration, but these changes also impacted the polis in return. The cult of Hekate was used in a number of ways as an icon of the new urban identity. As the focus of the cult was shifted to the polis, the polis simultaneously fixed attention to the cult to gain recognition from a network of Greek poleis. Various kinds of communication at the sanctuary will be discussed here as they concern critical affairs pertaining to global politics and civic territory; even the way in which the goddess was renamed reflects the geo-political needs of the polis. Finally, the coinage of Stratonikeia in particular will be examined as an urban context of the cult, especially showing how the image of Hekate came to stand for the polis itself.

\subsubsection{Scope and Network}

Regarding the extent of its network, the sanctuary of Hekate at Lagina underwent at least three important periods. The first period is when it was a local shrine to Hekate in the marginal, crossroads zone of the polis of Koranza in the Late Classical and early Hellenistic period. Its circle of worshipers seems to consist primarily of the citizens of Koranza. The second phase is when the sanctuary was taken over by the rising polis of Stratonikeia, some eight kilometers to the south, and the goddess adopted as the main patron deity of the polis. This phase no doubt coincides with the absorption of Koranza as a deme into Stratonikeia. Evidence for this phase is found in an early second century inscription showing Stratonikeian involvement and even control, and the appearance of Hekate on the very first coins of Stratonikeia by the mid-second 
century BC, discussed below. In this period Hekate became a mainstream polis goddess, and her sanctuary at the crossroads of the Marsyas and Hayirlidere valleys was by now turned into a regular center of urban activity. Following the Mithridatic wars, a third phase in the expansion of the sanctuary's network began when Stratonikeia successfully petitioned Sulla and the senate of Rome for a grant of asylia (inviolability) for the sanctuary. ${ }^{265}$ Stratonikeia had greatly suffered while supporting Rome: using the sanctuary to obtain these privileges proves both its political and symbolic value for the polis - Sulla's letter was inscribed on the temple walls. Hekate gained international fame as cities from across the Greek world recognized Rome's grant of asylia. The first reference to this is in an inscription immediately following the Senatus consultum, calling for a list to be inscribed at the sanctuary of the names of all the 'cities, kings and rulers' who acknowledged the asylia of the sanctuary and participated in the contests of the penteteria. ${ }^{266}$

The resulting roll-call of 57 cities is an impressive outcome of the manpower invested by the polis in making this festival known throughout the Greek world, with clusters not only in Karia and Ionia, but also Lykia, the Dardanelles, Thrace, the Peloponnese, and even the Eastern Mediterranean (Figure 5.25). ${ }^{267}$ Though not strictly arranged, the list begins with cities in Karia, including Mylasa, ${ }^{268}$ followed by those from Asia Minor, and then expanding to include Delphi, Olympia (Elis), Athens, Argos in the west to Damascus and Seleukeia Pieria along the eastern fringes of the Greek world. Lagina was fixed as a bright central dot on the mental maps of the Greek world, as is evident from Strabo's inclusion of the sanctuary as one of the few Karian places in his description of Karian geography. The panhellenic festivals got much of the Greek world involved in celebrating the cult of Hekate, while making them acknowledge

\footnotetext{
265 Senatus consultum de Stratonicensibus of 81 вс; I.Stratonikeia 505-508.

266 I.Stratonikeia 507 , lines $3^{-7}$, cited above.

267 I.Stratonikeia 508 , though incomplete, lists the 57 cities that recognized the asylia of the sanctuary and participated in the Hekatesia-Romaia. During 1999-2002 several coins were also found at the site from Alabanda, Bargylia, Rhodes, Ephesos, and Miletos, see Tirpan and Sögüt (2007b), 394. The impact of this in terms of network is further discussed in van Nijf and Williamson (2015); van Nijf and Williamson (2016); and more on the Romaia in van Nijf and van Dijk (2020).

268 Stratonikeia had a border conflict with Mylasa in the mid-second century BC, which may have been resolved by this time: I.Mylasa 134, and Ager (1996), no. 101. Mylasa, however, may well have taken advantage of Stratonikeia's weakened position after the Mithridatic wars to continue its own expansionist policy, see Cousin and Diehl (1898), 433-435 (although they place this in the context of the sympoliteia with Olymos and Euromos, which they date to the mid-first century вС; see Reger (2004), 164-168 for an earlier date in the third century вС).
} 


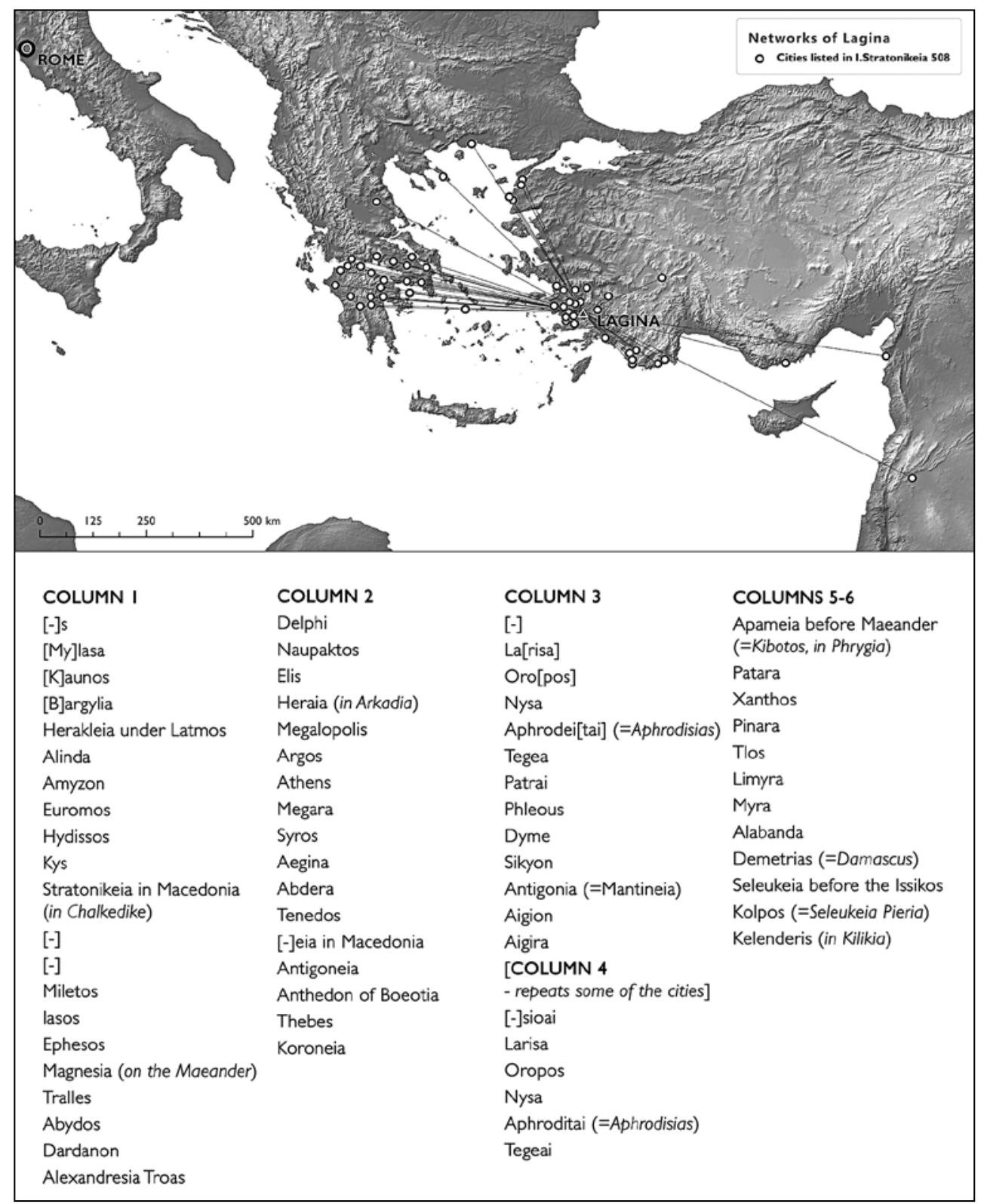

FIGURE 5.25 The social network of Lagina. Map and table show the 57 cities listed on the temple walls of Lagina (I.Stratonikeia 508 ) recognizing the asylia, following the Senatus consultum de Stratonicensibus of $81 \mathrm{BC}$ (I.Stratonikeia 505) and participating in the Hekatesia-Romaia festivals 
the bond between Stratonikeia and Rome. Stratonikeia thus skillfully used the event to achieve 'global' recognition not only for the sanctuary but also for the polis itself; the organization of the festival of the two goddesses ensured a strong network of allies who were obliged to participate, for reasons of both cult and politics. ${ }^{269}$

Stratonikeia clearly used Lagina as its formal debut into the global network of poleis. In this the polis was following the lead of other cities, the most famous of which is Magnesia on the Maeander, who over a century earlier went on a quest in much the same way for worldwide recognition of the sanctuary of Artemis Leukophryene - the first efforts were in vain, but in a renewed offensive they ultimately drew a response from some 16o cities across the Greek world, ranging "from Sicily to Iran." ${ }^{270}$ Magnesia catalogued these responses on the walls of the nearby agora, grouping them geographically, as did Stratonikeia later at Lagina. ${ }^{271}$ John Ma refers to this practice as not just reflecting the active 'mental map' of the times, but specifically creating it from the perspective of the city. ${ }^{272}$ The temple of Hekate at Lagina, then, became Stratonikeia's map of the world, showing its own position among the cities whose esteem mattered most to the developing polis.

The shift in the scope of the sanctuary of Hekate at Lagina is truly impressive. The goddess literally moved from the margins of Koranza into the mainstream as she became a poliad deity of Stratonikeia. At the hands of the polis she was even transported beyond civic territory to being a goddess of international fame with a panhellenic festival, demonstrating the complete symbiosis between the city and the sanctuary.

\subsubsection{Civic Decrees}

Like Labraunda, the sanctuary of Hekate at Lagina was used to mark important political events. It has already been shown above how in the early second century the sanctuary was used to honor the Rhodians by introducing the cults

269 Laumonier observed a parallel with the intertwinement of local and super-regional interests in the Amphiaraia festival in Oropos, on the border between Boeotia and Attica in Greece; this festival was also a celebration of Rome within the cult framework of Amphiaraos, Laumonier (1958), 359; but see also Errington (1987), who shows the worship of Thea Romē as a sign of gratitude in response to Roman intervention of some kind.

270 Rigsby (1996), 18o; p. 179-279 on the 6o asylia inscriptions at Magnesia, with over 100 cities only appearing in lists; van Nijf and Williamson (2016).

271 Rigsby (1996), 180. The temple of Artemis Leukophryene faces the agora.

$272 \mathrm{Ma}(2003), 12-13$, and 20-22 on the asylia of Magnesia on the Maeander and its responses in the context of peer polity interaction. The long list of inscribed sacred land transactions would have had a similar function, as argued in Horster (2010). 
of Helios and Rhodes at Lagina. ${ }^{273}$ The small architrave inscription donated by Hermias Athanagoras, discussed above, may further reflect Rhodian influence if it was in fact dedicated by a Rhodian. ${ }^{274}$ Later, after Stratonikeia was delivered from Rhodes by Rome, the sanctuary was also used to mark observance to the Romans. The question of whether the temple frieze belongs in this category has been discussed above, but the Hekatesia-Romaia festival is proof beyond doubt, along with the official documents pertaining to this festival that were inscribed on the walls of Hekate's temple.

Also like Labraunda, the walls of the sanctuary became an important public and municipal archive. Both sanctuaries contained important letters from the rulers that concerned both sanctuary and city: Labraunda contained the dossier of correspondence with the Hellenistic kings concerning its relationship with Mylasa in the third century $\mathrm{BC}$, and the temple of Hekate at Lagina also bore an important letter by Sulla, the most powerful ruler at that time in the early first century BC. Yet rather than concerning a controversy between city and sanctuary, this letter reveals their already inseparable relationship Lagina is for both parties as good as a code-word for Stratonikeia.

The Senatus consultum de Stratonicensibus from 81 в , was the document in which Rome formally recognized Stratonikeia's loyalty during the Mithridatic wars, acknowledging all the losses incurred by the polis and listing the grants of compensation awarded by the ruling power. ${ }^{275}$ This was an essential and vital political document to the polis that was kept safe in the most sacred place - on the walls of the temple itself. If, as van Bremen suggests, it was inscribed on the southwest wall of the temple, then it would have faced the rows of seats along the southwest stoa (Figure 5.8). ${ }^{276}$ This would have been a highly conspicuous place, forming the visual background to whatever events took place in the area between the temple and the stoa. The document was not only the confirmation of the status of asylia for Lagina, but it also described the significant territorial expansion of Stratonikeia granted by Rome, which included the area

273 I.Stratonikeia 504, discussed above under Priesthoods.

274 I.Stratonikeia 1424 (= EA 29 (1997), 98-99, no. 17); because of his Dorian name, Şahin believes he was Rhodian, p. 26; discussed above.

275 See also Sherk and Viereck (1969), no. 18, 105-111; Rigsby (1996), 418-423; Knäpper (2018), 254-255. Tac. Ann.3.62 mentions Stratonikeia as one of the cities that appeared before the tribune of Tiberius for continued recognition of asylia.

276 I.Stratonikeia 505 is the Senatus consultum de Stratonicensibus of 81 BC. This document and the following list of cities recognizing the asylia (I.Stratonikeia 507-508) were inscribed on the temple walls, Trrpan et al. (2012), 195; van Bremen (2010), 493-495 locates them more specifically on the 'south' (= southwest) wall. 
down to Keramos, Themessos(?) along the coast, as well as the produce from the villages in their countryside. ${ }^{277}$

Of course the extension of asylia was directly relevant to the sanctuary itself, as was the ensuing festival of the Hekatesia-Romaia and the list of the cities throughout the Greek world that further acknowledged this pact and participated in the celebrations (Figure 5.25). ${ }^{278}$ These inscriptions clearly documented a kind of contract between Stratonikeia and Rome, as the cult of Hekate was united with Rome. ${ }^{279}$ The cities further served as witnesses to this union; inscribing them in several columns across the walls of the temple was simultaneously a public, political, and a sacred act, perhaps even part of a ritual performance. ${ }^{280}$

A second manifestation of Hekate's intrinsic relationship with the city is the record of her epiphany. ${ }^{281}$ Mentioned in an elusive document that is not dated, it states that the goddess appeared and intervened in times of danger and sacrilege to the countryside and the sacred lands, as discussed above. ${ }^{282}$ It is tempting to associate this with her epiphany-like appearance on the frieze, especially in the gigantomachy on the northwest section. If her epiphany is connected to the reason behind the construction of the temple, then this would place it towards the end of the second century $\mathrm{BC}$, and would probably refer to some event during the Aristonikos revolt. This would only make sense, however, if the area around Stratonikeia or Lagina had actually been under attack, as Robert and Rostovtzeff believed, but has since been repudiated by

277 The grant of territorial concessions and asylia for Hekate's sanctuary is summed up in

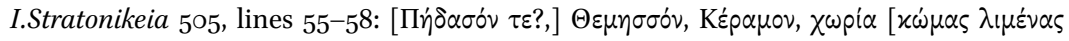

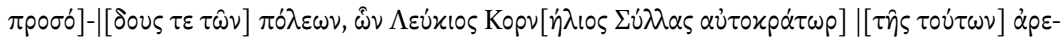

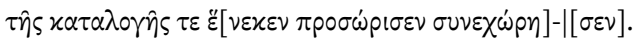

278 I.Stratonikeia $507-508$.

279 This foreshadowed the inclusion of the imperial cult at the sanctuary under Augustus, e.g. the statue of Augustus, I.Stratonikeia 1425 (=EA 34 (2002), no. 4). There may have been a parallel situation in Tralles, where a statue of Hermes was dedicated by the priest of Tiberius, Caesar and Hekate Augusta, I.Tralleis 11.

280 A parallel is found in the lists inscribed on the walls of the agora at Magnesia on the Maeander, mentioned above; Rigsby (1996), 180. See also IAph2007 8.27, the Senatus consultum de Aphrodisiensibus, from 39/8 BC, inscribed on the north parodos of the theater in the third century AD; also Ma (2000), 103.

281 An allusion to Hekate's epiphany is made in I.Stratonikeia 512 , lines $25^{-27}$, discussed further below. See also: Robert (1937), 461-462; Rostovtzeff (1941), 809; Laumonier (1958), 354-355; Marek (1988), 297-29; and van Bremen (2010), 499-502. Epiphanies as a sign of the dependency of the Hellenistic polis on its gods are also discussed in Wiemer (2009), 117 n. 4.

282 See also I.Stratonikeia 513. 
others. ${ }^{283}$ The area certainly was under attack, however, during the occupation of Stratonikeia by Mithridates VI Eupator, as discussed above.

The aftermath of the Mithridatic wars mark the first appearance of Hekate's new title of Soteira Epiphaneia (Epiphanous Savior), in the decree following the Senatus consultum and establishing the penteteric festival for Hekate and Thea Romê. ${ }^{284}$ This episode in the early first century вС is a much more likely context for her epiphany as it points to her role as religious or even spiritual focus during the hardships endured by the community. Adding these titles to the goddess' name was an extremely effective way to commemorate the event, but especially to communicate the sacred bond between the goddess and the city, directly announcing to all the protective role of the goddess and her intimate relationship with Stratonikeia. Using epiphanies in this way was certainly not unusual in the Hellenistic period; especially in the second century BC there seems to have been a surge of these which carried over into the first century $\mathrm{BC}$ - the account of the epiphany of Zeus Panamaros during Labienus's attacks in $40 / 39 \mathrm{BC}$, discussed below, is perhaps one of the most detailed that has survived. ${ }^{285}$

Renaming Hekate through the new epiklesis of Soteira Epiphaneia in essence rewrote her identity as the goddess who protects Stratonikeia. Although Hekate was obviously already heavily involved with Stratonikeia, this new name marked a pivotal moment in time, and place in the landscape, as being endemic to the very identity of the goddess - this is when the divine will of Hekate to protect the polis was made clear and announced to all.

283 Robert (1937), 459-465 and Rostovtzeff (1941), 8 o9 believed Karia to have been a theater of this war, based on Aristonikos's attacks in the Myndos peninsula and the interpretation of Stratonikeia in Karia as the place of his capture (Eutropius iv.2o and Orosius v.10.1, both fourth century AD). Yet this could also be Stratonikeia on the Kaikos, in Lydia, e.g. Broughton (1934), Magie (1950) II, 1038-1039. Marek (1988), 297-298, sees no reason for Karia to have been involved in the wars at all, since it was beyond the area of Aristonikos's claims. Errington however observes that Rome had much more support outside the province of Asia than within, Errington (1987).

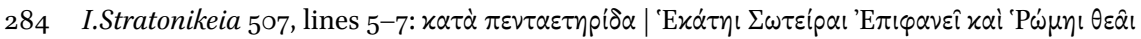

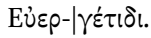

285 I.Stratonikeia 12 relates the miraculous epiphany of Zeus during the three-day onslaught by Labienus at his sanctuary in Panamara, discussed in more detail below, in Chapter 6 . The epiphany of Artemis Leukophryene at Magnesia on the Maeander is otherwise one of the best known, e.g. Chaniotis (1995), 162. Artemis Kindye also performed an epiphany at Bargylia during the Aristonikos wars, see Marek (1988), 297; Hotz (2005). On epiphanies in general, Graf (2004), Rostowzew (1920) and Pritchett (1979), 11-46 on epiphanies in military contexts. 
This is also the moment that was recalled when the goddess was honored as Hekate Soteira for restoring her sacred lands, as mentioned above. ${ }^{286}$ Another inscription speaks of the unanimous devotion and gratitude of the people of Stratonikeia to Hekate who clearly intervened in the wrongs done to her and to them, implying some kind of epiphany or manifestation of divine power. ${ }^{287}$ Although the context is unclear, the reference to 'the sacrilege of our country which is sacred and inviolate' could place this inscription after the Mithridatic wars. ${ }^{288}$ This way of describing the sanctity and inviolability of 'our lands' illuminates the way in which the property of the goddess and the polis were interwoven; one of the aims in obtaining the grant of asylia for the sanctuary after the Mithridatic wars was surely to extend protection over at least a part of civic territory which belonged to the sanctuary.289

The Senatus consultum inscription and her epiphany are two examples of high profile political and religious events that directly concerned the city and the sanctuary, and that were subsequently recorded at Lagina. Another strong indication is the use of the sanctuary as an urban podium, a place where honors were bestowed upon individuals for their selfless deeds and services for the community.

Together with the decrees, the number of honorific monuments makes up the largest category of inscriptions at the sanctuary after the lists of priests, even in the Hellenistic period (see Table 5.1 above). Not all of these can be directly associated with statues, but there are enough to indicate that the

286 I.Stratonikeia 510, see above under Economic resources.

287 I.Stratonikeia 512 was found in numerous pieces - the central eight or so lines seem to be missing. The goddess is honored by the demos for saving them from danger through a positive sign, thereby providing freedom and autonomy, lines 4-9; lines 21-27 show how the desecrators of their sacred and inviolate country were cut down and brought to jus-

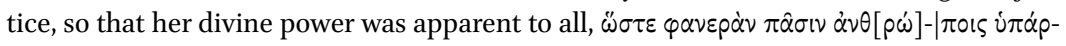
$\chi \varepsilon เ \nu \tau \dot{\nu} \nu \tau \hat{\eta} \varsigma \theta \varepsilon \hat{\alpha} \varsigma \dot{\varepsilon} \nu \alpha \dot{\rho} \gamma \gamma \varepsilon 1 \alpha \nu$ (lines 26-27). This may well be why the inscription was given such a prominent place on one of the antae of the temple, Tirpan et al. (2012), 195; on this phenomenon, Roels (2018a).

288 I.Stratonikeia 512 , lines $21-22$, discussed above. It is true that the historical context is vague, and van Bremen (2010), 499-502 leans towards a date in the second century вс, based on the language and letter shapes. The lack of any epiklesis for Hekate could also support a date prior to the Mithridatic wars, yet on the other hand the clear recognition of asylia argues for a date after the Senatus consultum de Stratonicensibus of $81 \mathrm{BC}$; van Bremen also admits that the destruction which the decree mentions may well indicate a date in the first century вс.

289 On grants of asylia as possible incentives to declare more and more land as 'sacred', see Chapter 4 on the sanctuary of Sinuri. 
interior of the sanctuary must have been rather crowded with them. ${ }^{290}$ One of the earliest inscriptions at the sanctuary, from the early second century BC, is an honorific decree concerning a Stratonikeian who was praised in Lagina by the Karian Chrysaoric League, presumably where his fellow citizens could see it. ${ }^{291}$ Fragments of another honorific decree, widely dated to the first century вс, list the boule and demos praising an individual for his good deeds to population the polis. $^{292}$

Of special interest is a statue base from the second part of the first century dedicated to the brothers Menekles and Epainetos, both adopted by Antipatros of Koraia, and situated in a prime spot, just in front of the propylon next to the west stoa. ${ }^{293}$ For his goodness and benefactions, Menekles was awarded a golden crown, a statue, presumably the one on this monument, and a meal in the prytaneion. Epainetos was to receive a golden crown and a (bronze) statue for the continuous goodwill which he displayed towards the polis. The monument is long, but based on the inscriptions it nonetheless seems to have been intended to hold only the two statues of these brothers. They were honored in perhaps the most prominent place in the sanctuary, since their statues would have been one of the first things encountered upon entry, closing off the theatron at the southeast end and 'framing' the sanctuary in the background (Figure 5.26).

Finally, a more plebeian expression of urban involvement may be found in the informal writing, i.e. 'graffiti', at the temple itself, especially the several outlines of feet on the krepis of the temple, discussed above (Figure 5.17), ${ }^{294}$ but also the figures of a dog, perhaps Hekate's? Although we know neither who etched their feet at the shrine nor when they were carved, they are certainly

290 Honorific decrees are found in I.Stratonikeia $523-543$. See also Laumonier (1958) 364 for a summary of dedications by priests, ex-votos, statues, and even statuettes or medallions

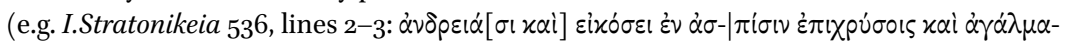
$\sigma \omega v$, awarded to a priestess, see commentary Hatzfeld (1920), 78, no. 8).

291 I.Stratonikeia 1418 (= EA 35 (2003), 1-7), also discussed above in connection with Rhodian presence at Stratonikeia.

292 I.Stratonikeia 1423 (=EA 29 (1997), 95-96, no. 13). The name of the individual has not been preserved, but his deeds may have been of a financial nature, since the tamiai, or treasurers, are also listed in the header.

293 I.Stratonikeia 1426 and 1427; the monument was excavated in 1996, see Tirpan (1997) and Tirpan (1998a) on its restoration. Şahin discusses the fact that the demotic of Koraia was erased in Epainetos's inscription as an indication of perhaps some confusion due to the adoption, p. 27. See also the discussion by van Bremen on the practice of adoption in Stratonikeia, based in part on this monument which had newly been brought to light, van Bremen (2003a), 17-19.

294 Discussed above under Public space. For footprints on monuments, see Dunbabin (1990). 


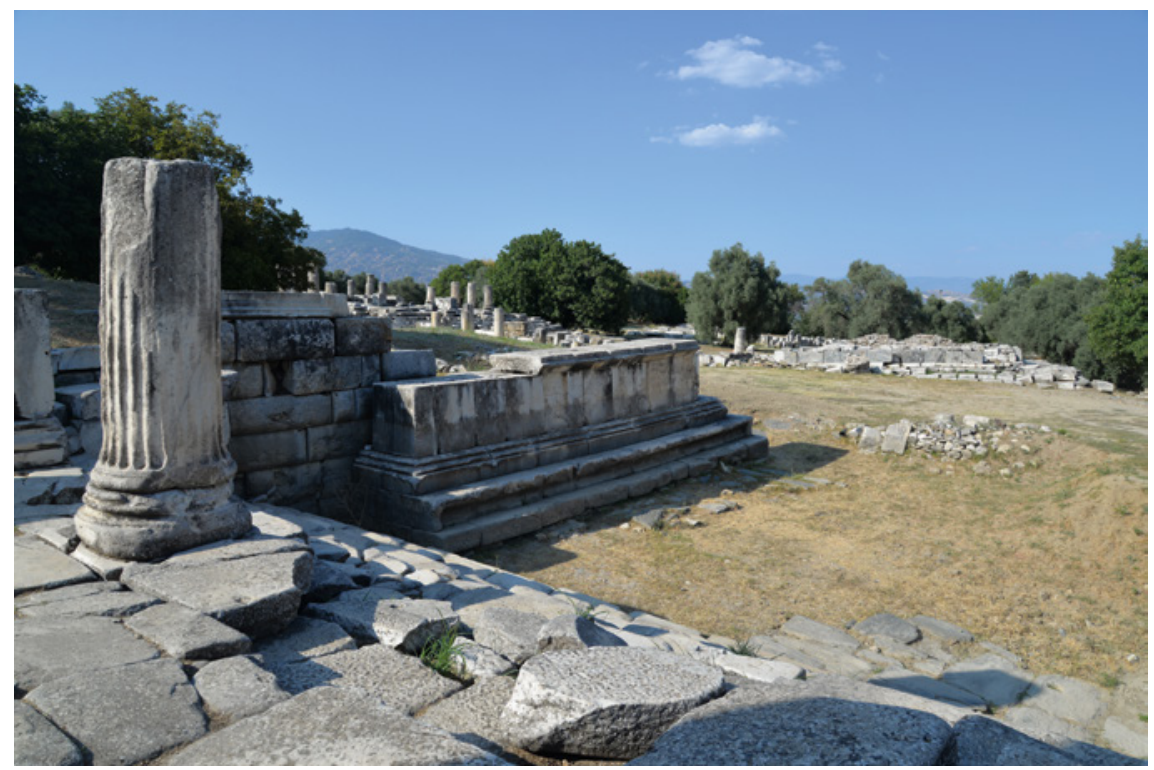

FIGURE 5.26 Lagina. Monument for Menekles and Epainetos, I.Stratonikeia 1426-1427, seen from the propylon with the temple and altar in the background PHOTO AUTHOR 2019

testimonies of the liveliness of the sanctuary. Moreover, while these are all around the temple, they are most concentrated along the southwest side, opposite the theatron. Various topoi 'graffiti' are furthermore found in the propylon, including one of Leon in which he marked his spot ('Leontos topos') below the theatron and between the propylon and the monument for Menekles and Epainetos - a very prominent spot indeed.

The sanctuary clearly functioned as public and urban space, with its decrees and monuments, and historical documents, but also signs of everyday use - it was a lived-in sacred space, used by a large cross-section of the population. With its agora-like setting, it was surely intended as an annex to the urban environment of town.

\subsubsection{Cult Iconography in Urban Contexts}

Imagery can be a highly efficient means of communication, especially on coinage as it passes from hand to hand. The imagery on the coinage of Stratonikeia not only effectively communicated the relationship between the goddess and the polis, but also advertised it and in so doing helped to (re)produce it. Along with Zeus, Hekate is portrayed on the earliest coins of Stratonikeia, issued some time after the city's independence from Rhodes. Andrew Meadows dates 


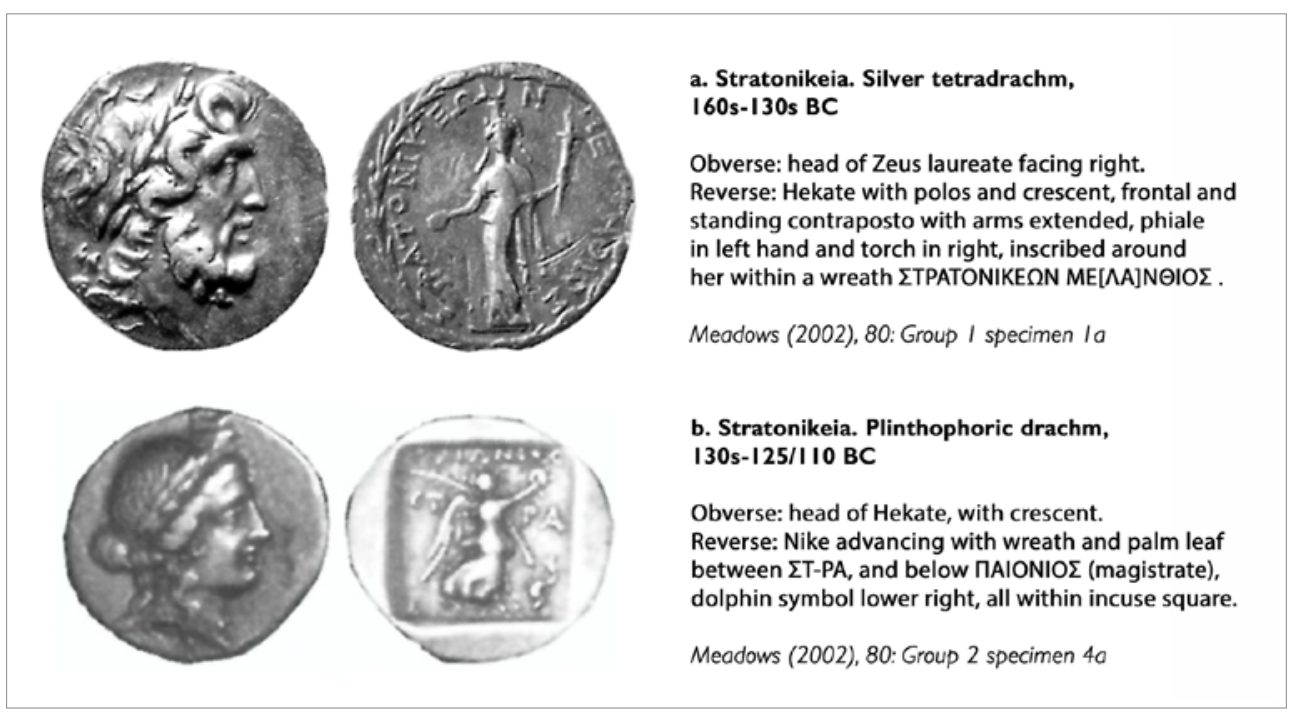

FIGURE 5.27 Stratonikeian coins showing Hekate and Zeus

them to the period between the 16 os and 13 Os BC (Figure 5.27a, Group 1, shows an example from this group). ${ }^{295}$ Hekate is shown on the reverse, standing frontally, wearing a polos with a crescent, and holding a torch in her right hand with a phiale in her left. Stratonikeia is shown either abbreviated or written in the genitive, as $\Sigma$ TPATONIKE $\Omega \mathrm{N}$, encircling Hekate; the name of the stephanephoros, or civic magistrate, appears as well. Generally speaking, Hekate is not a civic goddess and so rarely appears on coins, yet her identity here is unmistakable due to her attributes, particularly the torch and the crescent moon. Her frontal stance and outstretched arms, as in the temple frieze (Figure 5.15), may reflect her cult image. ${ }^{296}$

295 Head's BMC Caria from 1897 was the leading source on Stratonikeian coinage until the discovery of the Muğla hoard in 1965, with 290 silver coins from the second and early first century вс, considerably extended the base for the typology of the Hellenistic coinage; this was first published in von Aulock (1967) and SNG von Aulock. Meadows has done more extensive analyses of this hoard together with other known specimens and has revised the chronology, discerning four typological groups for the silver issues in the Hellenistic and early imperial period; Meadows (2002). During the 1999-2002 excavations at Lagina, another 188 coins were found, more than half of which were minted by Stratonikeia; Tirpan and Söğüt (2007b), 394.

296 If so, this would imply some sort of protective architecture at the sanctuary, since Meadows' dates for this coin group (16os-130s BC) are earlier than the generally believed dates (late second to early first century вс) for Hekate's temple complex at Lagina; for an alternative, earlier view of the temple chronology, see van Bremen (2010), 502 . 
Hekate is later portrayed on the obverse, starting with Meadows' Group 2, as smiling and crowned with her crescent, with an alighting Nike on the reverse, extending a wreath and holding a palm branch (Figure $5.27 \mathrm{~b}$ ). These coins clearly aim to associate the concept of victory with Hekate and Stratonikeia. Meadows connects Group 2 with the Aristonikos revolt, but they may also anticipate or even coincide with the major construction activity at Lagina towards the end of the second century вс. ${ }^{297}$ Group 3, a strongly devaluated version of Group 2, is placed by Meadows in the context of the Mithridatic wars in the early first century вс. ${ }^{298}$ Hekate had a very high profile at this time; the Senatus consultum for Stratonikeia was posted at Lagina, and her enigmatic epiphany, discussed above, may have been related to this turbulent period. 299 Most of the coins known from the hoards from this period depict Hekate rather than Zeus. ${ }^{300}$ In any event, they continue to repeat the familiar pattern of goddess, city, and victory, and Hekate's image remains on the coinage until well into the Roman period; she is often combined with the new Gestalt of Zeus Panamaros, who is shown as a rider-god on horseback (Chapter 6, Figure 6.30a, c). ${ }^{301}$ Besides her festivals and processions, the image of Hekate, in such a close context with the polis, was itself a fundamental building block in the symbolic shaping of the polis. ${ }^{302}$

With their ubiquity, coins were thus an excellent mechanism of advertising the interlocking equation of goddess with city, bringing the idea of this relationship to wherever the coin happened to travel. Other less mobile signs of Hekate in the urban area of Stratonikeia would include her statue, as mentioned above, at the gateway of the city in the Roman period, before the bronze doors, perhaps looking out over the nearby necropolis. ${ }^{303}$ Alfred Laumonier discovered a small marble block or altar showing Hekate in relief worked into the walls of one of the houses in Eskihisar. ${ }^{304}$ Finally, in the later second century, the notable Marcus Sempronius Clemens dedicated a shrine, next to the

297 Meadows (2002), 101-107. But see also van Bremen (2010), 502. Meadows (2018), discusses the rising phenomenon of poliad deities on coins across the Greek world in the second century вС.

298 Meadows (2002), 107-111.

299 See above and I.Stratonikeia 512.

300 Meadows (2002), 107-111.

301 Meadows (2002), Group 4a.

302 Meadows (2018). See Chapter 2 on Paasi's view of symbolic shaping as part of the creation of regional identity, Paasi (2009).

303 Robert (1940), 237-238; see above, under the section on the Sacred road.

304 Laumonier (1936), 321-322, fig. 33. He lists the dimensions as $59(\mathrm{~h}) \times 29(\mathrm{w}) \mathrm{cm}$; the moulding at the top and bottom may indicate a small altar. 
bouleuterion in town, which included a statue to Hekate. ${ }^{305}$ This may have been the statue of the goddess next to that of Zeus Panamaros, before which the choir boys were instructed to stand as they sang their hymns to both the gods during their festivals. ${ }^{306}$

To recapitulate, in the transition towards becoming an urban sanctuary, the scope of Hekate's cult at Lagina underwent three major phases: 1) in the Late Classical and early Hellenistic period when it principally belonged to the polis of Koranza; 2) at some point in the second century, when it was used as a common focus for the new urban population of Stratonikeia; and 3) after the Mithridatic wars in the first century, when it was used to gain recognition from Rome and to connect to the larger Greek world. Especially the second period shows Stratonikeia gaining control over the cult while the area was still under Rhodian rule. Once liberated, Stratonikeia selected Hekate to symbolize the polis on its very first coinage, mediatizing the intimate relationship between the goddess and the polis right from the start. This would have foregrounded Lagina in the mental topography of the citizens of Stratonikeia, giving it a prominent spot in their mind's eye; the goddess became a common focus that helped shape the identity of the polis both symbolically and territorially. ${ }^{307} \mathrm{In}$ the third phase, after the Mithridatic wars, the union between city and sanctuary took on a new direction as the cult of Hekate was used by the polis to engage in geo-politics via the Senatus consultum de Stratonicensibus, then using this to expand the festival of Hekate to include the goddess Roma, and finally by soliciting recognition and participation from the wider Greek world, stretching from Olympia in the west to Damascus in the east. Using Lagina, Stratonikeia positioned itself on the map of places that matter, as Strabo's inclusions of milestones indicates (14.2.29). The Hekatesia-Romaia mediated local, regional, and global networks, under the soft power of empire. Publishing these central inscriptions at the sanctuary was a mass-advertising maneuver that sealed its fame through time, as a monument. In this way the collective memory of the polis, but also the wider Greek world, was shaped to meld the identities of Hekate and Stratonikeia as a powerful and indivisible force. Yet the agency was ascribed to Hekate. The goddess was positioned as the main actor in this new relationship - it was not the manpower of the Stratonikeians that ultimately

305 I.Stratonikeia 289, lines 10-11: Hekate's statue was alongside those of Zeus Panamaros, Artemis, Asklepios, and Hygieia.

306 As prescribed by Sosandros, son of Diomedos, in I.Stratonikeia 1101, line 5; discussed above under Festivals.

307 On 'symbolic' and 'territorial' shaping as one of the stages in building a regional identity, see Paasi (2009), discussed in Chapter 2, and below. 
counted in the public eye, but the divine will of the all-powerful goddess who selected the polis to cherish and protect.

\section{Interpreting Change in the Relationship between Stratonikeia and Lagina}

Whether driven by ritual, geographical or political motives, the new polis of Stratonikeia clearly relied in several ways on the older cult of Hekate at Lagina, implicitly using it to develop its identity as a polis and legitimate its own position. In the process, the city took the cult place of the goddess from being a wayside shrine at the edge of the Marsyas valley to a central focus of the polis, foregrounding it in the cognitive collages of its citizens.

Considering its location, it would be easy to classify Lagina as a frontier sanctuary. It is situated near the natural boundary of the Marsyas river to the east and the rising Gökbel mountains to the north; in fact it significantly extended the visual range of the polis in these directions, as well as a good part of the Marsyas valley looking southeast (Figure 5.6). That this concerns a sanctuary to Hekate is already suggestive of a liminal location. One function at Lagina that coincides with sanctuaries at areas of borders or crossings are the major festivals and especially the element of competition. This fits in with de Polignac's ideas on the need for controlled rivalry as well as mediation at borders, as well as with Sinn's ideas of such sanctuaries as places of refuge, because of their liminal positions. ${ }^{308}$ However, the sanctuaries discussed in their studies were their primarily concerned with border conflicts or rights of passage and refuge. This is very different from the case of Lagina, which was turned into a great inter-state center through recognition of its asylia and its penteteric festival. Except for the unequivocal Stratonikeian presence, nothing else at this sanctuary speaks of the kind of territorial dominance or even aggression that tends to coincide with theories on frontier sanctuaries. ${ }^{309} \mathrm{Had}$ this been the case, then one would expect to see more of a landmark function of the shrine, especially in the direction of the Marsyas valley or the Gökbel mountains. Instead, travelers coming from these directions were apparently met with long blank walls. Added to this is the fact that we do not know the exact extent of Stratonikeian territory; Debord even suggested that it may have spanned the Marsyas to include villages in the lower foothills of the Oyuklu range, east of modern Yatağan, where Londarga and Koraia or Lobolda may

308 De Polignac (1994) and (1995); Sinn (1993).

309 De Polignac (1995), discussed in Chapter 2. 
have been situated (see Figures 5.1 and 5.21). ${ }^{310}$ Hekate is the goddess of the crossroads and Lagina is certainly near some important natural boundaries, yet this is not enough to warrant an interpretation of this wayside shrine as a political frontier sanctuary. There must have been other operative factors in the relationship between the city and the sanctuary.

The first factor is the role of the sanctuary in creating social cohesion within the polis. Ritual space at Lagina created an intense, enclosed space that was largely cut off from the world. This ensured a complete focus of the community onto the events taking place within its walls in a stage-like setting, complete with a theatron for ritual spectators. The spectacle became more and more the subject of the festivals, and it was clearly important that they capture the attention of the crowd. The kleidos agoge, the procession of the key, however is critically important in this regard, as it took the focus from the sanctuary, across the ancient landscape and through the communities still living there, and into the heart of town. This centripetal movement served to ensure the primacy of the new polis within the pre-existing older community. ${ }^{311}$ While one might interpret this as territorial domination, e.g. according with the model of the frontier sanctuary, ${ }^{312}$ in light of rational ritual theory such a sensational - and loud - procession moving through the landscape is viewed as a highly effective means of mass-advertising. ${ }^{313}$ The difference is key, as rather than imposing the ideology of territory, the ritual elicits a communal response. Such prominent ceremonies were excellent vehicles of common knowledge, as they created a unified focus for the community, providing a shared experience and a common bond. In this case the focus would also have been on the centricity of the new polis within the older local network of local communities that had by now been drawn into the polis as its demes. By promoting a goddess whom everyone already knew, but who was not central to any one particular community (although marginal to Koranza), the new urban center was able to pull the disparate communities together under one religious umbrella. Everyone could in principle have an equal share in this cult, regardless of origin or for the most part social standing (with the exception of the priesthood and the kleidophoros). The potential of the cult of Hekate that Stratonikeia realized was its ability to create a common focus for the communities that now constituted the polis, thereby enabling social cohesion.

310 Also the map in Debord (1994).

311 See Graf (1996) on centripetal versus centrifugal processional trajectories; discussed in Chapter 2 and above.

312 De Polignac (1995), 40-41.

313 Chwe (2001) on 'rational rituals', discussed in Chapter 2. 
A second political factor in the potential of the shrine for the polis is its ability to create a sacred, and political, network with peer Greek cities. ${ }^{314}$ The way in which Stratonikeia used the sanctuary after the Mithridatic wars, first to obtain the grant of asylia and the territorial expansion and then to expand its circulation by extending the cult to include Thea Romē, and by creating panhellenic festivals with games and competition, shows how the city was building a political network through cult. ${ }^{315}$ The package deal they created of peer interaction, observance to the superpower Rome (through recognition of the asylia grant and participation in the festivals that now included Thea Romē) and the element of inter-urban competition was apparently an offer that was difficult to refuse. The resulting network of cities involved at the sanctuary is eventually what placed Lagina on the map, with Stratonikeia in its slipstream. The quadrennial festivals with contests were used to elevate the city to the international level of cult recognition, although this network is mostly one dimensional, i.e. consisting of the cities that voluntarily recognized the asylia of Lagina and participated in the games of Hekate and Rome. But thanks to the inscription from Kos, we know that at least on a regional level, the 'local panhellenic' games at Lagina allowed Stratonikeia to join the multi-dimensional network of the athletic festival circuit that was active in Karia and Ionia, including among others Halikarnassos, Miletos, Kolophon, Nysa, and Metropolis. ${ }^{316}$ These added networks were of course on top of the membership which Stratonikeia already had in the Chrysaoric League thanks to the Karian villages in its territory. The live market (biotike agora) may also have contributed to the wider network, if it in fact indicates that the sanctuary functioned as a kind of emporion.

With regard to networks, Stratonikeia may already be seen as part of the network of cities in the Chrysaoric League, with a vote based on its membervillage count. ${ }^{317}$ With the festivals at Lagina, however, the sanctuary would be a strong node with at least 57 ties to all of cities that recognized the asylia and joined in the festival, as well as those such as Kos who were not on the list but

\footnotetext{
314 See Ma (2003) on the peer-polity interaction among poleis in the Hellenistic period.

315 Rutherford (2007), discussed in Chapter 2.

316 Iscr.Cos, EV 203; discussed above under Games.

317 The villages in the League are known to have included Mylasa, Stratonikeia, Amyzon, Alabanda, Alinda, Thera, and Keramos, and possibly Panamara, see Gabrielsen (2011), 341-345. Strabo 14.2.25 mentions that Stratonikeia was admitted by virtue of its Karian villages, and that the members of the Chrysaoric League were allowed a representational vote corresponding to the number of villages in their territory. Gabrielsen (2000), 161 suggests that gaining more villages to increase the weight of the vote was the main reason behind Stratonikeia's policy of expansion.
} 
nonetheless participated in the quadrennial games. Lagina was thus a prime central node in the network, a 'hub' which deserved its place as a milestone in Karia, recognized by Strabo. Strictly speaking, Stratonikeia was itself also a node in this network, but with much weaker ties, occupying a more peripheral position. In a strict sense, the polis may thus be seen as a satellite of the sanctuary, even though it was in fact the main actor that had established this network with the wider Greek world through the combination of cult and politics.

This is a very rudimentary analysis of the networks that were established through Lagina. Further data-mining of the inscriptions could perhaps strengthen or lend nuances to this image, e.g. by examining aspects of reciprocity such as Stratonikeian presence at festivals of the cities who participated in the Hekatesia. However, this preliminary approach already elucidates the important role of Lagina in building a network that reinforced the regional position of Stratonikeia. Building this network and the emphasis on social cohesion both have everything to do with the third factor, constructing the urban identity of Stratonikeia in the wider region. Network and social cohesion were both instrumental to the rising polis in anchoring its position in the area, which of course began when it absorbed the local independent communities, poleis in their own right, and turned them into demes of the polis. As part of Koranza, Lagina was a considerable actor in this initial movement of territorial shaping, the first of four stages in the process of region-building in Paasi's model (discussed in Chapter 2 above), and followed by symbolic shaping, institutionalism, and establishment through external recognition. ${ }^{318}$

Territorial shaping thus took place by the incorporation of the ancient villages and their lands within the scope of the polis. Through this model we can envision Stratonikeia as further shaping, or at least consolidating its relatively new territory and the communities within through the cult of Hekate, who became the symbolic focus for the composite polis. A parallel might be found in the Asklepieion on Kos, thought to have been re-founded partly as a response to the synoikism of 366 в and a means of self-expression by the newly shaped polis. ${ }^{319}$ Sanctuaries clearly function as coordinating mechanisms, weaving together identity out of community and a sense of place. One way of territorial shaping was by adding the viewshed from the sanctuary to that of the polis, thereby greatly expanding its visual region, as the sanctuary and sacred

318 Paasi (2009), 133-137, see Chapter 2.

319 Interdonato (2016), 175, who considers the self-expression of the polis as a complementary motive to the Ptolemaic self-promotion at the sanctuary; she does not go into as much detail on the length of time, nearly a century, between the synoikism and the expansion of the polis, but a similar gap may also be noticed at Lagina. 
road served to connect both spaces and embed them in the mental maps of the worshipers. With Lagina, the processions along the sacred road especially would have helped unify the city, cutting across old boundaries and drawing the population in from the ancient communities towards the new urban center, as they followed the highly symbolic key of the goddess. The spatial memories created in this way allowed them to literally "perform the region," perhaps even re-enacting the foundation of the city. ${ }^{320}$ The frequency of these processions, the festivals, but also her imagery on civic coinage, served to embed a firm mnemonic pattern between the goddess, the city and the territory in the minds of its citizens, much like an emblem or a logo. ${ }^{321}$ This repetition implies a high degree of institutionalism; the demos and boule were already the main actors in this process, but the formation of the priesthood of Hekate and the kleidophoros as new civic roles expanded the range of critical actors that (re)produced this process of regional identity. These roles were fulfilled by members of the elite from different parts, or sub-regions, throughout the territory; this was critical in creating both hierarchy and unity within the area of the polis. $^{322}$

Hekate's emblematic role was further employed as a political tool to gain the grant of asylia for Lagina from Rome as well as a territorial grant which extended the legal reach of the polis down to the coast. The ensuing joint festivals of Hekate and Rome compelled the rest of the Greek world to acknowledge the inviolability of the sanctuary, implicitly acknowledging in the meantime the sovereignty of Stratonikeia and her newly won territory. In this way, the fourth stage in building regional identity, that of establishment through external recognition, was realized for Stratonikeia while strengthening its network ties of cult and politics. When Labienus desecrated the sanctuary of Hekate at Lagina in lieu of Stratonikeia, he was in fact confirming the success of this relationship.

In effect the image of the goddess, with her divine authority, stood for the city and so her epiphany as savior of the city was the logical climax of this relationship. Renaming Hekate as Epiphaneia Soteira presented the goddess as the ultimate actor in the regional identity of Stratonikeia; it was her divine will to protect the integrity of the city and its lands. Cult may have been shaped by the

320 Donaldson (2006); also 'performing the landscape': Dwyer and Alderman (2008); Pearson (2015). For the ritual dynamics, see especially Chaniotis (2013) with bibliography.

321 This would also have been a result of Mylasa's capitalizing on the images of Zeus Labraundos and Zeus Osogollis for its own heterogeneous community, made up of demes and syngeneiai; see Chapter 3 .

322 Paasi (2009), 133 on the importance of local elite as actors in negotiating identity through power relations; see also the priesthood at Panamara below, under Chapter 6 . 
necessity of politics, but politics also followed the authority of cult in - both were intertwined in a symbiotic relationship. Hekate is traditionally a goddess of the liminal zones, and although it is not inconceivable that this may have been one of the reasons why her cult was chosen, i.e. to watch over the borders of the newly formed 'city-state', her shrine at Lagina was in itself not a frontier sanctuary in the defensive sense: if anything, it was a portal of connectivity between the polis, its own citizens, and the wider political world. But her role in identifying with the polis may also explain her shape as a 'regular' monomorphic, rather than trimorphic, deity - for Stratonikeia she needed to be a goddess of unity, rather than ambiguity.

The next case study will show how Stratonikeia repeated much of this pattern with the sanctuary of Zeus Panamaros, at the opposite end of the spectrum of Stratonikeian territory. 